\title{
Facility Effluent Monitoring Plan for K Area Spent Fuel Storage Basin
}

\author{
G. S. Hunacek
}

Dan Publined

August 1996

Preparad for tha US. Departmant of Energy

Assistert Secretary for Ervizormental Maragarnent

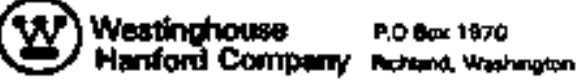

Meneownert and Doweres Contrectar tor the

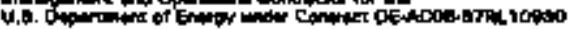

Approved for public release; distribution is unlimited 


\section{RELEASE AUTHORIZATION}

Doetrment Wumbar: WHC-EP-0497, Rey. 2

Documem This: Facilgty Effiluent Honitoring Plan for $K$ Area Spent Fuel Storage Basin

Rolata: Dutt: $\quad$ a/za/sts

This document was reviewed following the procedures descrited in WHC.CM-3-4 and is:

APPROVED FOR PUELIC RELEASE

WHC Imomnution Helease Admintstrmion Speciallet:

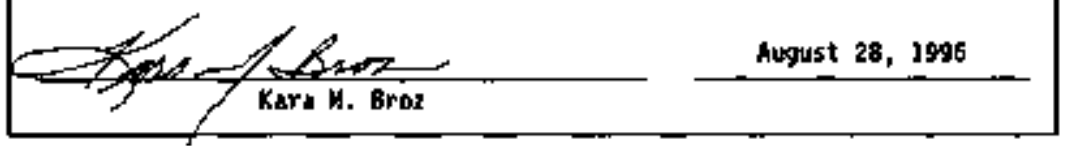




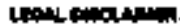

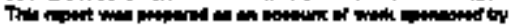

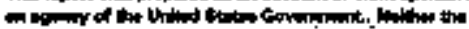

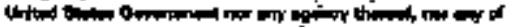

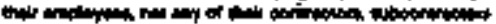

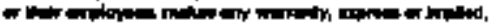

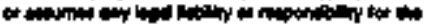

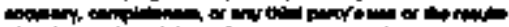

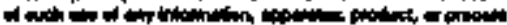

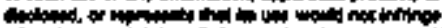

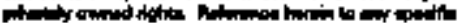

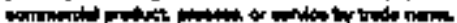

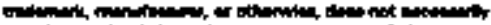

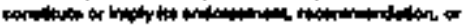

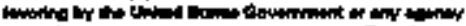

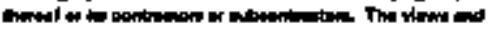

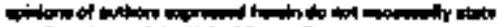

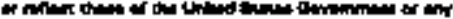
cincin thend.

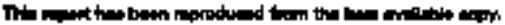

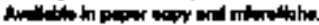

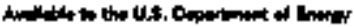
in

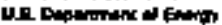

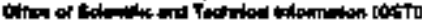

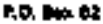

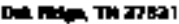

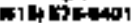

$\mathbf{x}$

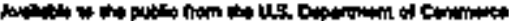

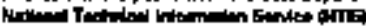

Btis has hay Red

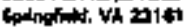

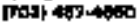

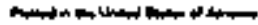

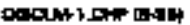


THIS PAGE INTENTIONALLY LEFT BLANK 


\section{WFORMATION RELEASE REOUEST PUELIC DOCUMENT CHANGE/REVISTON}

ishort Fom No. 1)

1 Baso Documerit ID Number WHC-EP-D497-1

2 Gase Cocument Tille

FACILITY EFFLUENT MONITOAJNG PLAN FOR K AREA SPENI FUEL STORALE BASTN

3 Change/Haviawan Number REV 2

\begin{tabular}{|c|c|c|}
\hline 4 & Change/Rlavigion Detta & $08 / 29 / 96$ \\
\hline 5 & Unclassified Catogory " & Uc - 2050 \\
\hline
\end{tabular}

I verify the changerrevision to the bast document indicated above

- Complies with the provians of WHC CM.3.4

- Contasns no bumited Use rilotination

- Contans no chassified or Appliad Technology references

- Does iol chende the intent of mearung of the base documont

- And. the base document itself is approved tor public telease

7 Responsital Manager C Cefigi-Price

MȘH $\times 3-79$

Telephone Number $373-9596$
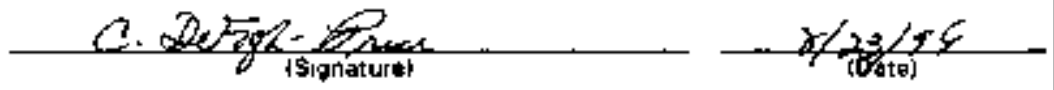

8 Informathon Rele日eg Admınıgtratıon Spacialıgt *
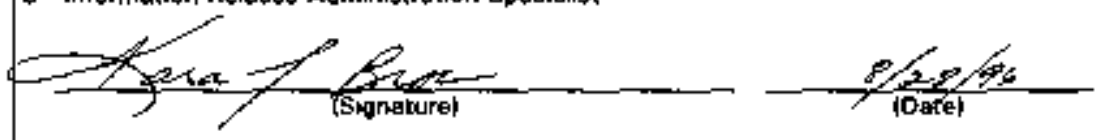

"Pequared arly for full revigions transmitted la OSTI

+ "Roquered only for tull ravisions 


\section{THIS PAGE INTENTIONALLY LEFT BLANK}




\section{APRoval ract}

Documest tile: Facllity Efonest Montbrieg Ptan for $X$ Are Spant Fuel Stringe Bavin

Prepared by:

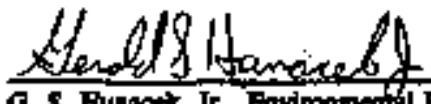

G. S. Bullacti, Jr., Envimoreatid Engives

Neckor and Eviromeat sufeky

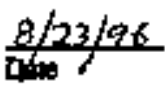

Appoied by:

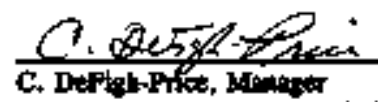

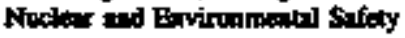

Appowed by

Approved by:

\section{P. Dipdita, Tem Lead}

Air w Wale Sorvice blegration $\frac{-1806}{100}$

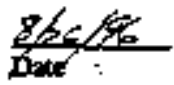

$\Rightarrow+\infty t-9 t$

Dave

$8 / 24 / 96$

Dre 
WHC-IPA-0+97, Rew. 2

This jagte tontionally laft blenk. 


\title{
FACIITY EFTLUENT MONITORDG PLAN FOR K AREA SFENT FUEL STORAGE RASIN
}

\begin{abstract}
AXSIRACT

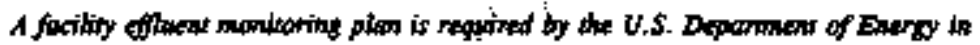
DOE ONder SACO It for any openations that inwolve hazardous meterials and rodioactive

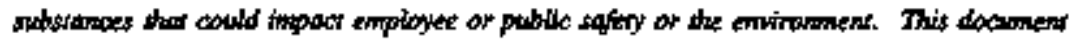

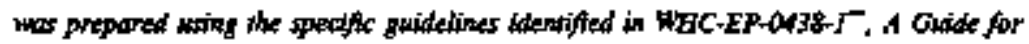

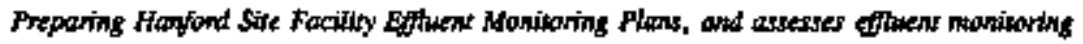

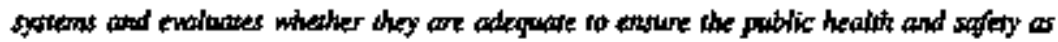

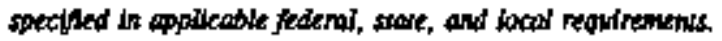

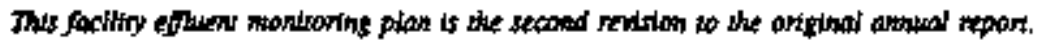

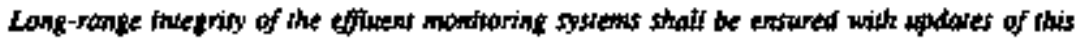

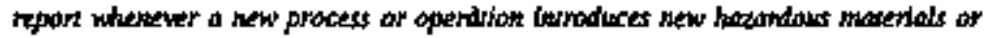

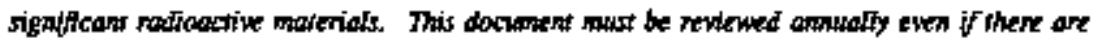

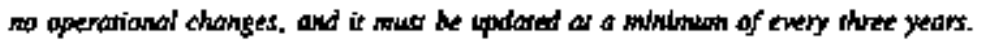

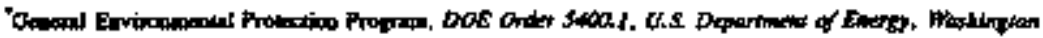
D.C., ther.

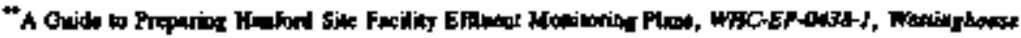

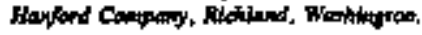


HHC-EPP-0497, Rev, 2

This pase intentionatly left blenk. 


\section{CONTINTS}

1.0 K AREA SPENT FUEL STORAGE BASTN $\ldots \ldots \ldots \ldots \ldots \ldots \ldots \ldots \ldots \ldots$

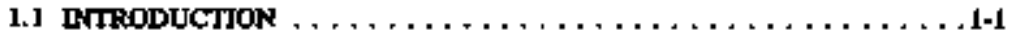

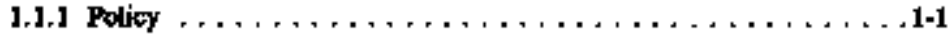

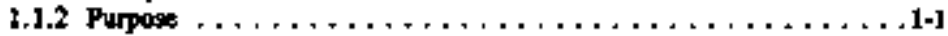

1.t.3 Soope $\ldots \ldots \ldots \ldots \ldots \ldots \ldots \ldots \ldots \ldots \ldots \ldots \ldots \ldots.] \ldots \ldots$

1.1,4 Disussion $\ldots \ldots, \ldots \ldots \ldots \ldots \ldots \ldots \ldots \ldots \ldots \ldots \ldots, \ldots \ldots$

2.0 FACIUTY DESCRIPTION $\ldots \ldots \ldots \ldots \ldots \ldots \ldots, \ldots \ldots \ldots, 2-1$

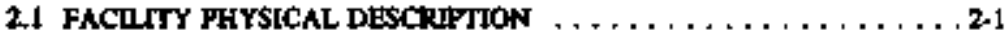

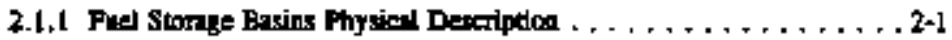

2.1 .2 J706 KE Offix Complta $\ldots \ldots \ldots \ldots \ldots \ldots \ldots \ldots \ldots .2 .5$

2.1.3 1908 KE Outfall Fhyrical Description . . . . . . . . . . . . . . 2-6

2.1.4 161 KE Oulfill Physteal Dessription (Nor Gperational) + . . . . . . 2-6

2.2 FACNITY PROCESS DESCRIPTION $\ldots \ldots \ldots, \ldots, \ldots, \ldots, 2.7$

2.2.1 Fud Stornge Batins Procent Desqiptin $\ldots \ldots \ldots \ldots \ldots \ldots$ 2.7

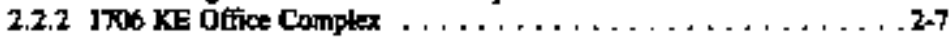

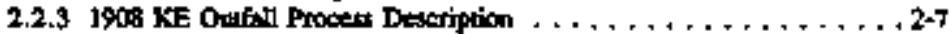

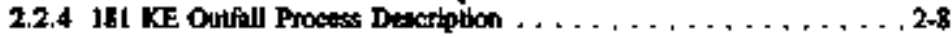

2.3 IDENTIFICATTON AND CHARACTERIZATTON OF

POTENTLAL SOLRCE TERMS . . . . . . . . . . . . . . 2-8

2.3.1 KE Fuel Storrge Basin Source Term $\ldots \ldots \ldots \ldots \ldots \ldots \ldots$ 2-8

2.3.2 KW Fuel Storage Basia Source Term . . . . . . . . . . . 2-6

2.3.3 Potental Nosadioactine Source Terms . . . . . . . . . . . . 2-9

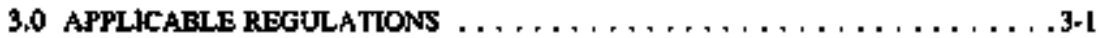

3.1 U.S. DEPARTMENT OF ENERGY ORDERS $\ldots \ldots \ldots \ldots \ldots \ldots \ldots$.

3.1.1 Geneal Emvironmerital Protestion Profran (DOE OCderr $\$ 400.1) \ldots \ldots \ldots \ldots \ldots \ldots, \ldots \ldots$

3.1.2 Rediation Protection of the Puthlic and Emironanent (DOE Order $5400.5 \ldots \ldots \ldots \ldots \ldots \ldots$. $\ldots \ldots \ldots$

3.1.3 Envimmental Proketion, Salety and Healh Prolection Standerds (DOE Order \$480.4) . . . . . . . . 3.7

3.1.4 Environmeatal Provection, Safty, and Health Protection Infuratation Reporting Requimbetems (DOE Onder \$484, I) . . . . 3-7

3.J.5 Radioactive Waste Management (DOE Order 5820.2A) . . . . . . 3-T

3.1.6 Environmentol Regulatory Guide for Radiologleal EMuken

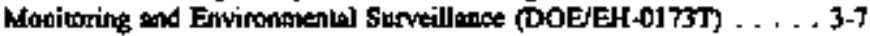

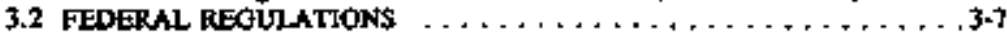

3.2.1 Natioasl Emistion Standards for Harordouts

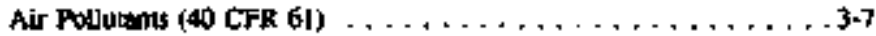

3.2.2 State Operating Permit Poggram (40 CPR $\left.\eta_{0}\right) \ldots \ldots \ldots \ldots \ldots$ 3-8 


\section{CONTENIS (Contined)}

3.2.3 FPA-Administered Permit Programs: The National Pallutant

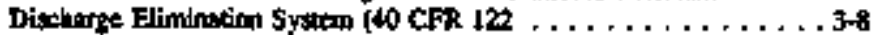

3.2.4 Nationail Primary Drinling Wust Regulotions (40 CFR [4]) . . . 3.9

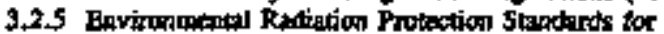
Manapenent and Dipossal of Spent Noclear Fuci, High-Level and Tranauranic Radiogctive Wastes (40 CFR (9]) . . . . . . . . . . . . . . . . . . . . .9

3.2.6 identification and Listhe of Bwrardous Waste (40 CFR 261) . . . . \$-9

3.2.7 Designation, Reporteble Quntities.

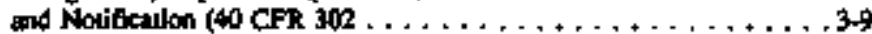

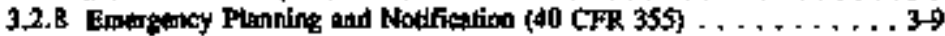

3.2 .9 Effluent Guidehines Standards $\{40 \mathrm{CFR} 401-471) \ldots \ldots \ldots \ldots \ldots$

3.3 INDUSTRY STANDARDS UNDER AMERICAN

NATIONAL STANDARDS INSTTIUTE . . . . . . . . . . . 3-10

3.3.1 Guide to \$aptpling Aitwone Radioactive Msterialg in Nucler Facilities (ANSI NI3.1-1969) . . . . . . . . . . . 3-10

3.3.2 specification and Performunes of Onde lnstrumbution

for Continumasty Moxiloring Rodidactivby in

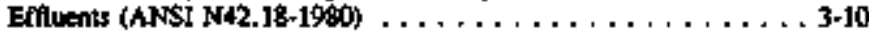

3.4 WASHENGTON STATE REGLRATIONS . . . . . . . . . . 3-11

3.4.1 Water Quality \$ondards for Groundwatro (WAC 173-200) . . . . 3 3-1]

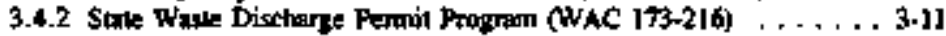

3.4.3 Underground Injection Control PTogran (WAC (73-218) . . . . 3.11

3.4.4 National Pollukants Discharge Elimination \$ysem Permil Program (WAC 173-220) . . . . . . . . . 3-11

3.4.5 Fudatal Waver Pollhution Control Ael - Extablishment of Implemenuation Pagcedutes of Appltealion for Certification (WAC $173-25$ )

3.4.6 Submission of Plans and Reports for Construction uf Wastewaler Facilities (WAC 173-240) . . . . . . . . . 3-12

3.4.7 Dangrous Waste Requlations (WAC 173-303) . . . . . . 3-12

3.4.8 General Rejukstions for Air Pollution Sourees (WAC 173-400) . . 3-J2

1.4.9 Air Opertatiag Pesmil Progtan (WAC 173.401) . . . . . . . . 3.12

3.4.10 Conurols for New Sources of Toxic Air Polldanis (WAC 173-460) . . . . . . . . . . . . . 3-13

3.4.1] Ambient Air Quality Stankards and Entissian Limits For Rationuclides (WAC $173-480) \ldots \ldots \ldots \ldots \ldots \ldots$ 3.13

3.4.12 Rojiation Ptutection - Air Enissioas (WAC 246-247) . . . . . 3-13

3.5 LOCAL REGULATHONS $\ldots \ldots \ldots \ldots \ldots \ldots \ldots \ldots \ldots \ldots$

3.5.I Benton Counly Air Rollution Control Authodby (80-7) . . . . . . . 3-13 


\section{CONTBNIs (Comilimed)}

3.6 PERMTIS $\ldots \ldots \ldots \ldots \ldots \ldots \ldots \ldots \ldots \ldots \ldots \ldots \ldots \ldots \ldots$

3.6.1 Authorization vo Discharge Under MPDES for

Slarmunter Dixharges Associnted wh

Construction Activities (WAR-10-000F)(EPA 1992A) . . . . . . 3-14

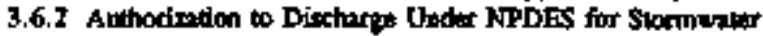

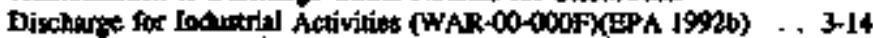

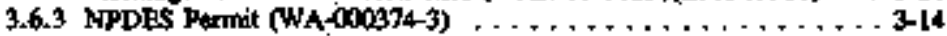

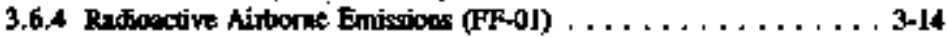

3.6.5 Nothe of Construetion kt KE Bath $\ldots \ldots \ldots \ldots \ldots \ldots \ldots$ 3-1S

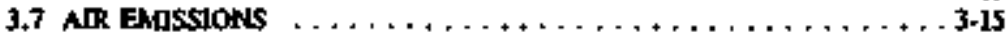

3 L LQUTS EFFLUENTS $\ldots \ldots \ldots+\ldots \ldots \ldots \ldots \ldots \ldots \ldots \ldots+\ldots+36$

4.0 IDENTIFCATTON AND CHARACTERIZATION

OF EFFLUENT STREAMS $\ldots \ldots \ldots \ldots \ldots \ldots \ldots \ldots \ldots \ldots \ldots \ldots$

4.1 IDENTIFCATION AND CHARACTEEJZATTON OE

CONTAMTNANTS TO EACH EFFLUENT STREAM $\ldots \ldots \ldots \ldots \ldots$ 4-1

4.1.1 Routine Cperating Conditions . . . . . . . . . . . . . .

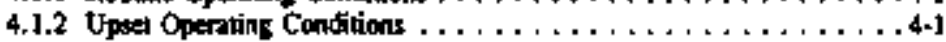

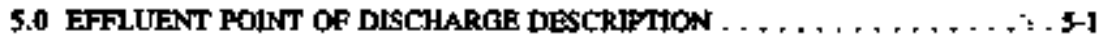

5.I ARPORNE DLSCHARGE POINTS $\ldots \ldots \ldots \ldots \ldots \ldots \ldots \ldots \ldots$.

$5.1 .1105 \mathrm{KW}$ Basin Exhaust Vents . . . . . . . . . . . . . 5-1

5.1.2 105 KE Barin Exhaus Vants (Closed by December 1995) . . . . \$-1

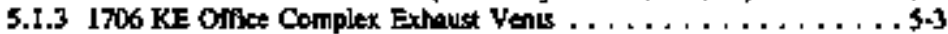

5.2 LQUID DISCHARGE POINTS $\ldots \ldots \ldots \ldots \ldots \ldots \ldots \ldots \ldots \ldots$

5.2 .1 18]-KE Outfan (NPDES Outfall 003) $\ldots \ldots \ldots \ldots \ldots \ldots \ldots \ldots$.8

5.2 .21908 KE Outfill (NPDES Outfall DOA) $\ldots \ldots \ldots \ldots \ldots \ldots \ldots .5$

6.0 EFFLUENT MONTTORINQISAMPLING SY\$TEM DESIGN CRITERIA . . . . . 6-I

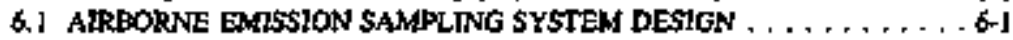

6.2 LIQUID EFFLUENT SAMPLNG SYSTEM DESIGN $\ldots \ldots \ldots \ldots \ldots$, 6 -

6.3 OFF NOTMAL REIEASES (UPSET CONDIMONS) , . . . . . . . . 6-2

70 CHARACTERIZATION OF CURRENT EFFLUENT

MONTTORING StSTEM $\ldots \ldots \ldots \ldots \ldots \ldots \ldots \ldots \ldots \ldots \ldots \ldots$.

7.1 INSTRUMENT DESCRIPTION $\ldots \ldots \ldots \ldots \ldots \ldots \ldots \ldots \ldots$ 7-1

7.1 .1 Air Sampling Equipmed $\ldots \ldots \ldots \ldots \ldots \ldots \ldots \ldots$. 7 1

7.1 .2 Water Sampling Equiphes. $\ldots \ldots \ldots \ldots \ldots \ldots \ldots \ldots \ldots$.1

7.2 INSTRUMENT SPECIFICATTONS $\ldots \ldots \ldots \ldots \ldots \ldots \ldots \ldots, 7$

7.2.1 Air SamplinelMoniterhe Equipmen1 . . . . . . . . . 7.1

$7,2.2$ Liguid SamplingMonitoriog Equipment $\ldots \ldots \ldots, \ldots, \ldots, 7.2$ 


\section{CONTENIS [Contoned)}

7.3 ALTERNATE MONTTCRDNG AND ASSESSIMENT METHODS . . . . 7-2 7.3.1 Albagte Air Mooilocing and Aswessmer Methad . . . . . . . 7-2

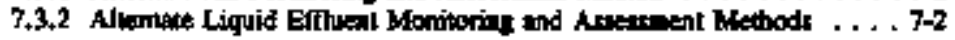

\section{B.0 HISTORICAL MONITORINO/SAMPL JNO}

DATA FOR EFFUUENT \$TREAMS $\ldots \ldots+\ldots, \ldots, \ldots, \ldots, \ldots,+\& 1$

B.J FORMAL CONDHTONS $\therefore \ldots \ldots \ldots \ldots \ldots \ldots \ldots \ldots$

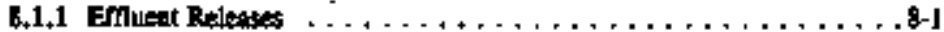

8.2 UPSET CONDITJONS $\ldots \ldots \ldots \ldots \ldots \ldots \ldots \ldots \ldots \ldots \ldots \ldots$ \&-2

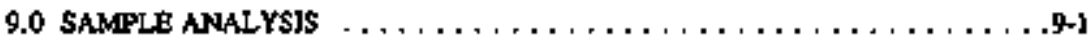

9.1 PURPOSE $\ldots \ldots \ldots \ldots \ldots \ldots \ldots \ldots \ldots \ldots \ldots \ldots \ldots \ldots \ldots . \ldots \ldots$

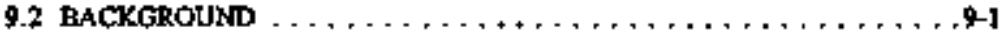

9.3 SAMPLING SCHEDUIE, FREQUENCY, AND SIRATEGY . . . . . . 9-1

9.3.1 Air Sompling Schedule, Frequency, and Stratedy , . . . . . . 9-1

9.3.2 wate sample, schedule, and frequency , . . . . . . . . . 9-2

9.3.3 Groundwate Mondoring . . . . . . . . . . . . . 9-2

9.4 SAMFL ANALYSIS, DETECTION, AND ACCURACY . . . . . . . 9-3

9.4.1 Alt Samplet $\ldots \ldots \ldots \ldots \ldots \ldots \ldots \ldots \ldots \ldots \ldots \ldots . . \ldots \ldots$

9.4 .2 Water Samples . . . . . . . . . . . . . . . . . . . . .9.6

9.4.3 Oroundwaver Samples . . . . . . . . . . . . . . .9-7

9.5 SAMPLE SHIPPING AND SAMPLE CHAIN OF CUSTODY $\ldots \ldots \ldots \ldots 9$

9.5.1 Sample Stipptog.$\ldots \ldots \ldots \ldots \ldots \ldots \ldots \ldots \ldots \ldots \ldots .9 .7$

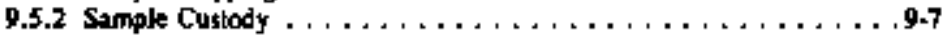

9.6 EFFLUENT MONTTORJNG PROCEDURES $\ldots \ldots \ldots, \ldots, \ldots, 9.7$

9.7 U.\$. DEPARTMENT OF ENERGY ANALYTJCAL AND

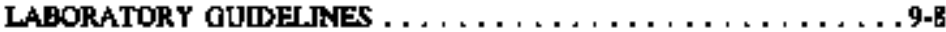

10.0 NOTIFICATION AND REPORTTNG REQUIREMENTS . . . . . . . . . 10-1

10,1 OCCURRENCE CATEGORJZATKON, NOTIFICATION,

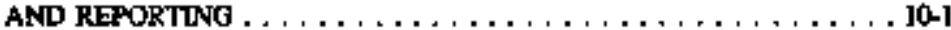

10.2 OCCURRENCE CATEGORIZATKON $\ldots \ldots \ldots \ldots \ldots \ldots \ldots$ 10-2

10.2 .1 Raptiosctive Releases $\ldots \ldots \ldots \ldots \ldots \ldots \ldots \ldots, 10.2$

10.2.2 Release of Hazardous Subsances'Regulared Pollutants/Oil . . . . 10-3

10.2.3 Discovery of Haxwotors Mateial Contanitation

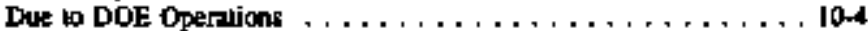

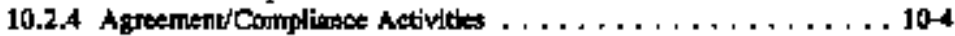

10.2.5 Exologieal Resoution . . . . . . . . . . . . . . I0-5 


\section{CONTENTS (Contmued)}

50.3 FEDERAL REQULREMENTS $\ldots \ldots \ldots \ldots \ldots \ldots \ldots \ldots \ldots$

10.3.1 Resourte Constervition and Rexovery At of $1976 \ldots \ldots \ldots \ldots$. . . . .

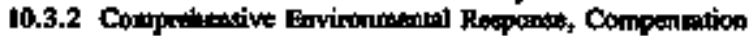

and t tabilty $\mathrm{Acl}$ of $1980 \ldots \ldots \ldots \ldots \ldots \ldots \ldots, \ldots, \ldots, \ldots$

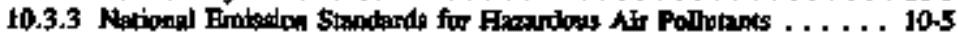

10,4 STATE REOULREMENTS $\ldots \ldots \ldots \ldots \ldots \ldots \ldots \ldots \ldots \ldots$

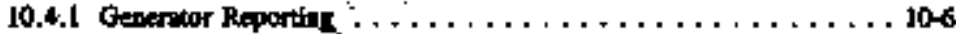

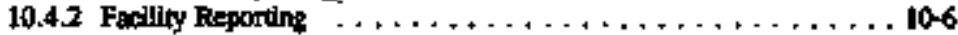

10.5 U.S. DEPARTMENT OF ENERGY REQUIRPMENTS $\ldots \ldots \ldots \ldots$ ID-6

10.5.1 DOE Order 5400.1, Chipter II, "Generl Envimonentel

Protestion Program - Notifientios and Repont" ... . . . . 10-6

10.5.2 DOE Ondes 5484.1, Enrirommantai Protextion, Safery and

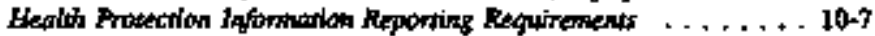

11.0 DNTERFACE WITH THE OPERATIONAL ENVIRONMTNTAL

MONITORING PROGRAM $\ldots \ldots \ldots \ldots \ldots \ldots \ldots \ldots \ldots \ldots \ldots \ldots$ 11-I

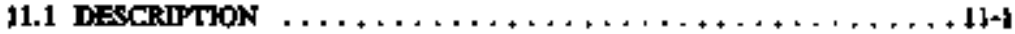

11,2 MURROSE $\ldots \ldots \ldots \ldots \ldots \ldots \ldots \ldots \ldots \ldots \ldots \ldots, \ldots \ldots, 11$

11.3 basts $\ldots \ldots \ldots \ldots \ldots \ldots \ldots \ldots \ldots \ldots \ldots \ldots, \ldots \ldots, \ldots \ldots$

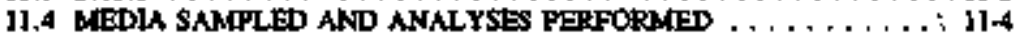

t1.5 LOCAMIONS . . . . . . . . . . . . . . . . . . . . t]-4

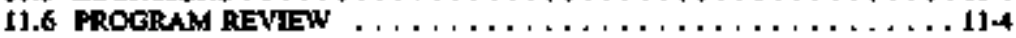

11.7 SAMPLER DESIGN $\ldots \ldots \ldots \ldots \ldots \ldots \ldots \ldots \ldots \ldots \ldots$

11.8 COMOMUNICATION $\ldots \ldots \ldots \ldots \ldots \ldots \ldots \ldots \ldots \ldots \ldots, \ldots \ldots$

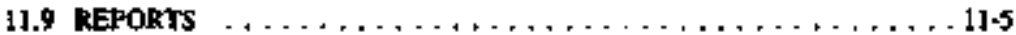

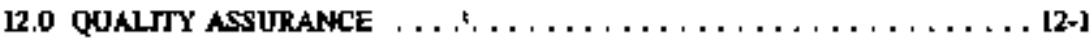

12.1 PURPOSE $\ldots \ldots \ldots \ldots \ldots \ldots \ldots \ldots \ldots \ldots \ldots \ldots \ldots \ldots$ 12-1

12.2 ODECTTVE $\ldots \ldots \ldots \ldots \ldots \ldots \ldots \ldots \ldots \ldots \ldots \ldots \ldots \ldots \ldots$ l2-1

12.3 REQUIREMENTS $\ldots \ldots \ldots \ldots \ldots \ldots, \ldots \ldots \ldots \ldots \ldots \ldots, \ldots$ 12-1

13.0 INTERNAL AND EXTERNAL PLAN REVIEW $\ldots \ldots \ldots \ldots \ldots \ldots$. . . . . .

14.0 COMPLIANCE ASSESSMENT $\ldots \ldots \ldots \ldots \ldots \ldots \ldots \ldots \ldots \ldots \ldots$ 14-]

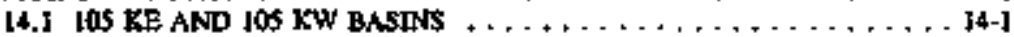

$14.21706 \mathrm{KE}$ MAIN FLOOR (0-FOOT LEVEL) . . . . . . . . . 14-1

14.31706 KE BASEMENT (4-METER [13-FOOT] LEVEL) . . . . . . . 14-1

14.4 1706 KE SLT-BASEMIENT (B-METER [27-FOOT] LEVEL) . . . . . . 14-]

I4.5 I706 KER MANN FLOOR (OFOOT LEVEL) . . . . . . . . . 14-2

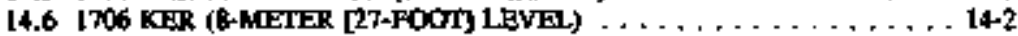

14.7 ITO6 KER (27-FOOT LEVEL) TUNNEL EXIALIST $\ldots \ldots \ldots \ldots, 14-2$

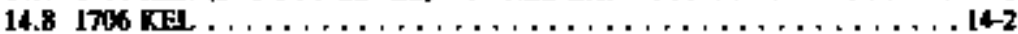


WHC-EP-(M9P, Bev. 2

\section{CONTrins (Centined)}

14.91908 KE OUTFALL $\ldots \ldots \ldots, \ldots, \ldots \ldots \ldots \ldots \ldots \ldots, \ldots, 2$

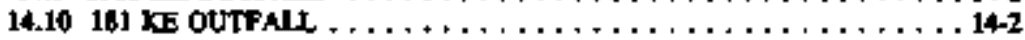

15.0 SUMMLARY AND CONCLUSIONS $\ldots \ldots \ldots \ldots \ldots \ldots \ldots \ldots \ldots$ J

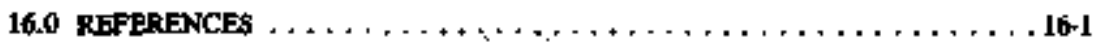




\section{LIST OF FGURES}

2-1 Henford Site Location $\ldots \ldots \ldots \ldots \ldots \ldots \ldots \ldots \ldots \ldots \ldots \ldots, 2$

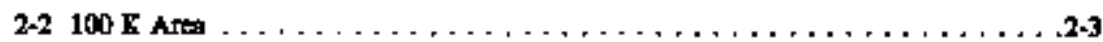

2-3 Fuel Storage Bastns Contruction $\ldots \ldots \ldots \ldots \ldots \ldots \ldots \ldots \ldots, \ldots, \ldots$

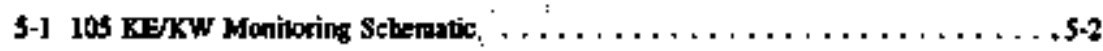

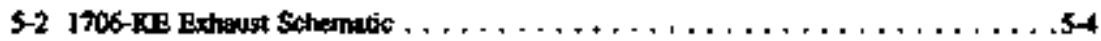

5-3 1706-KE Sampling Syunem Schemalic $\ldots \ldots \ldots \ldots \ldots \ldots \ldots \ldots \ldots \ldots$. .5

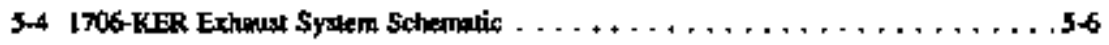

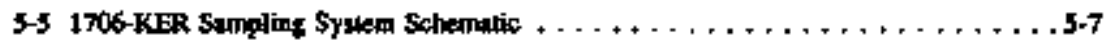

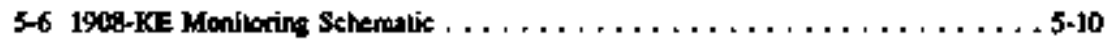

9-1 Groudwat Mondoorters wells $\ldots \ldots \ldots \ldots \ldots \ldots \ldots \ldots \ldots \ldots \ldots$.

\section{LIST OF TABLES}

3-I Applicable Requlations, Slandards, and Permits . . . . . . . . . . 3-2

4-1 K Ara liquid Efthenl Sureams $\ldots \ldots \ldots \ldots \ldots \ldots \ldots \ldots$

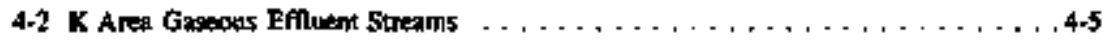

4-3 Normal Operation Radionctuve Emitrions for 1993 from $\mathrm{K}$ Area $\ldots \ldots \ldots \ldots \ldots$ 46

4-4 Upsa Operating Conditions fớ los SpenI Nuclear Fut Basio

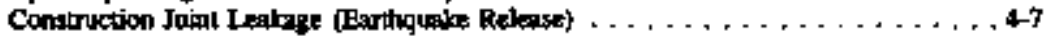

4-5 Upret Operating Conditicas for 105 SpenI Nuclear Fuel Basio Overfow Due to Pipe frrak $\ldots \ldots \ldots \ldots \ldots \ldots \ldots \ldots \ldots \ldots$

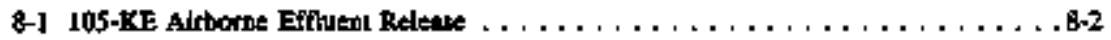




\section{UST OF TARil ns (Confinued)}

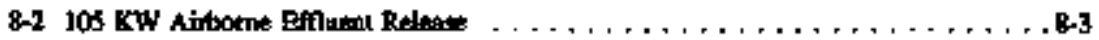

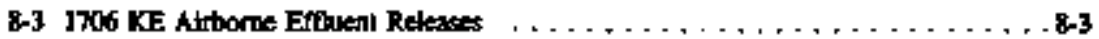

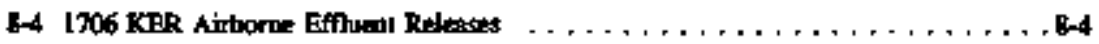

8-5 1908-k outall liquid Effluent . .

8-6 K Arta Normal Opention Dose Asessmenl for Airborne Emistoas - 1993 . . . B-5

8-7 K Area Normed Operational Dape Astessincent for Liquid Effiluents - $1993 \ldots \ldots$. . B-5

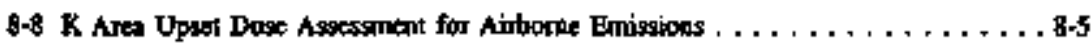

8- K Are Upaet Dose Assessment for Liquid EMueds . . . . . . . . . . . B-6

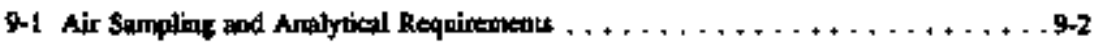

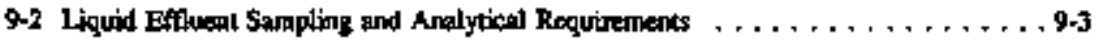

\$.3 Ratiochenical Asolyrical Methods and Limits for Airbome Samples . . . . . . . 9-5

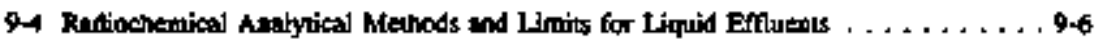

9-5 K Ares Efloent Sampling Procodnes $\ldots \ldots \ldots \ldots \ldots \ldots \ldots \ldots$

9-6 Data Analyes and Seatistical Treslment . . . . . . . . . . . . . . 9-9 


\section{LIST OF TERML}

\begin{tabular}{|c|c|}
\hline $\begin{array}{l}\text { ANSI } \\
\text { CERCLA }\end{array}$ & 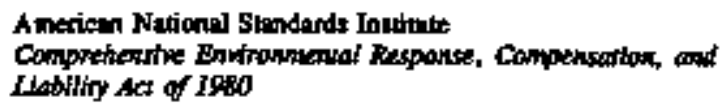 \\
\hline CFR & Cadit of Federal Regulitions \\
\hline DOE & U.S. Deparingent of Earery \\
\hline DOP & Dioctyl phthriate (tes) \\
\hline DOT & Departmeat of Trimportation \\
\hline EDE & Eflecthe Doose Equivilea1 \\
\hline EM & Effluent Monituring \\
\hline EMOP & Enwioumental Manicoting Plan \\
\hline EPA & U.S. Environmontsal Protection Areacy \\
\hline ES\&4 & Envircimental Provectivia, Safely, and Health \\
\hline FEMP & Facilily Effluent Monitorting Plen \\
\hline HEPA & High-Efriciency Particulate Adr \\
\hline K AFE & K Area \$pan! Fut Skorigge Bayim \\
\hline MDC & Minimal Ietectable Concentrition \\
\hline NESELAP & National Entissine Standards for Harasdious Air Pollhalmis \\
\hline NOC & $\begin{array}{l}\text { Notice of Construction } \\
\text { National Pollutan Dlecharte Elimination System }\end{array}$ \\
\hline OENP & Operational Eaviromntmipl Moniloring Progran \\
\hline QA & Quality Assurunce \\
\hline QAPYP & Queliny Asturance Project Plen \\
\hline RCRA & Resolice Construatom and Reconery Act of 1976 \\
\hline RCW & Reviged Code of Wasthrgem \\
\hline RL & Radionctive liqula \\
\hline RL & U.S. Depertipeal of Energy Richland Operations Office \\
\hline $\mathbf{S Q A}$ & Safety and Qually Assurance \\
\hline TL & Thermoluminescent Dosimetter \\
\hline TSD & Treatment, \$monepe and Disposal \\
\hline WAC & Washington Adaninismats code \\
\hline & Westingthouse Flanford Cosmpeny \\
\hline
\end{tabular}




\section{WHC-EP-0497, REV. 2}

This peose intencionally ieft bla?s. 


\subsection{K AREA SPENT FUFL STORAGE BASTN}

\subsection{INTRODUCTFON}

The purpose of this section is to provide finformation on the polky, pupose, and sipe of the

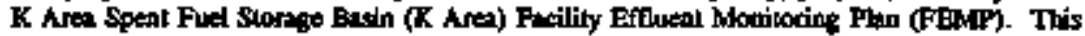

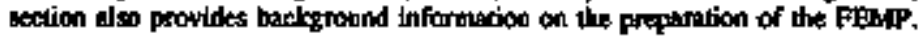

\subsubsection{Policy}

It is the policy of the U.S. Departaterl of Bargy (DOS) and Westinghouse Hanford Compesy w conduct effluent moriloring to deternine whether the puble and the

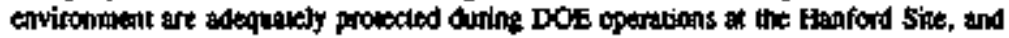
whether those operations ane th complinoe with DOE and other applicable federil, stett, ind local entistion standards and repuirements. It is alsa the policy of DOE and westingboute Hlanfond Company that efflucent moriloring programs meet high standards of quality and credibility.

\section{1 .2 Puprose}

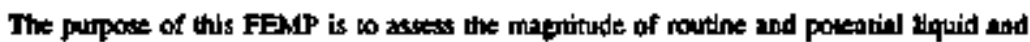
tirtorise efflutal teleases from the $\mathrm{K}$ Artes to determine the compliance and verify that the effuert monitoring systems and sompling proprams meel applicable federal, gaste, and bocal repultions. Where potential emvironmental problens ane identified from moaitorins, in

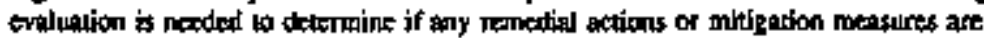
required.

\subsubsection{Seope}

The tcope of this document includes progran plans for monitoring and charieterizing

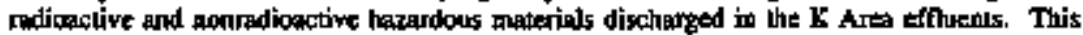
FEMP includes complete documentaion for both atborne and liquid effluenl monitoring systems thal monitor ractionactive and tontradionctive hazardous pollutants that could be discharged to the environmenl under routine and/or upset conditiods. This documentaliam is provided for each K Area faciliry that uses, generates, releases, or manarges significamt quantitieg of radipactive and tonradioartive hazdrdons materials that conld impact publis and

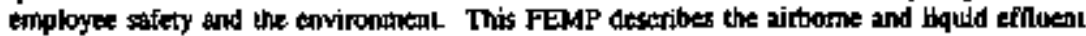
paths and the associalod pampling and monutoring systems of the $\mathbf{K}$ Area facilities. Stefficient information is provided on the effluent chartetteritios and the effhent monitoring systems so

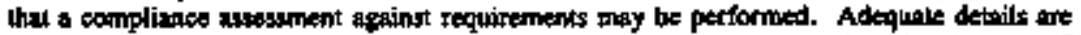
supplied such that redioartive and hamrious material soura terms may be felaned to specific 
effluent streams which are, in tom, rehaled to ditcherse pointe and findlly compant to the

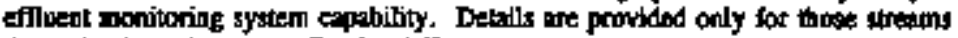

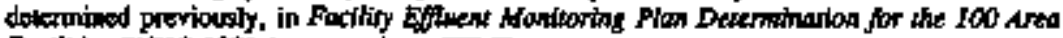

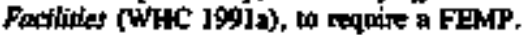

\subsubsection{Disurion}

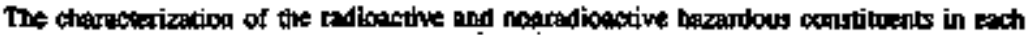

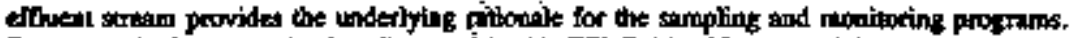

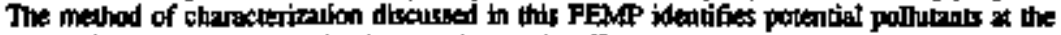

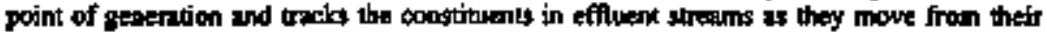

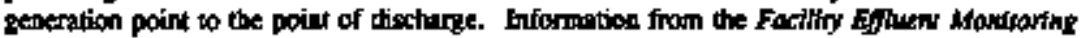

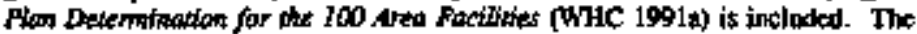
determinalions were mate in scordance wilb a Guide for Preparing Havori Faciling

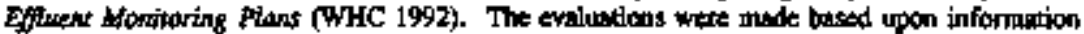
oboined in documents, interviews with chpnizant encineers, and personal observations.

During 1994, an assessment of potentipl emissions from the Hanford Site registered stack was made ko defrmine the complance of the resulting does with the "National Enisoion Standards for Horrdous Air Pollurtants (NESHAP\}," (40 CFR 61), Sobpart H. Sbels were destgnated at mejor or mlnor based on whether thetr potential emisstont would cousc an

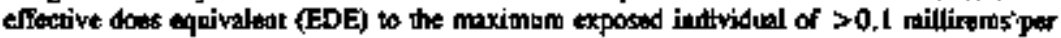
year (noredity).

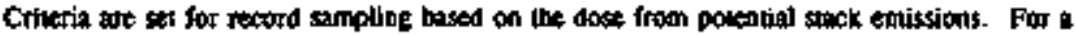

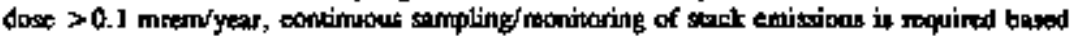

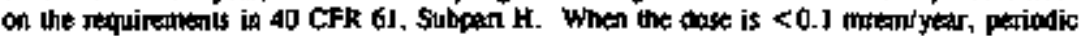

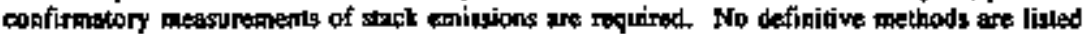
in 40 CFR 61, Subpart H, for performing periodic confirmatary mesurements.

With this informbtion the ractionuclide effunenl release points a $K$ Arta arte clastifisd as nipor atack emission points. This FEMP revigion reflects the atack status change of being a mitor rack emitsion point.

Radionuclides are emilied fron K Ared at gias lactions for air emigsions and one liquid eflucort tischart.

Radlonuctides are discharged to the air from: (I) the 10S XE Spenl Fuel Storage Basin; (2) the JOS KW Spent Fuel Storme Baxin; and (3) I706 KE office complen (a forme bboratory). The I706 KE Complex has the following dixcharge points: (1) I706 KE (main flopr, offoo [ti] kvel); (2) 1706 KE (bosement, minus 13-ft kvel); (3) 1706 KE

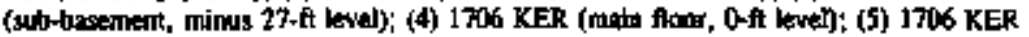

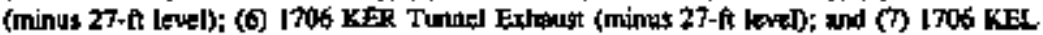
(0-ft level). The 1706 KE office complex is being osed to house $\mathrm{K}$ Basin personnel. 


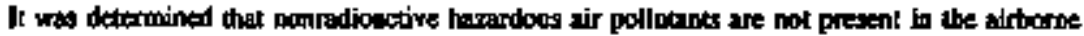

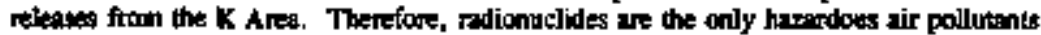
considend in this FEMP.

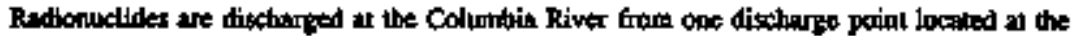

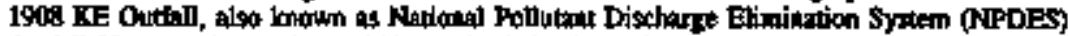

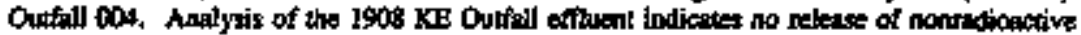

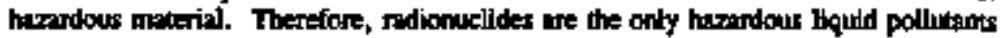
consididentad in thit FEMP.

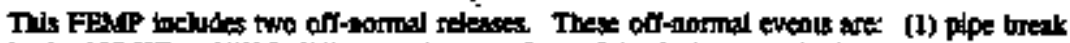

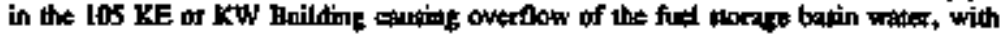

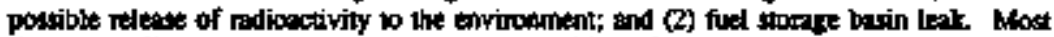
likely the off-normel would be lass nevere than wither of the two ovents listed abowe, because

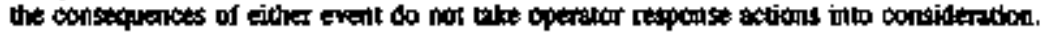


WHC-EP-0497, Rev, 2

This pope intentionslly ieft blenk. 


\subsection{FACILITY DESCRIMTION}

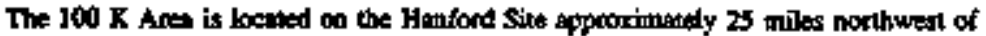
Rielulad, Wathingion, as shown in Figure 2-1. The $100 \mathrm{~K}$ Ara ibelf is ghowp in

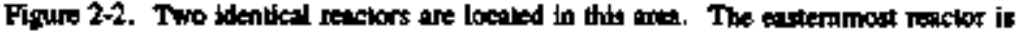
designated $106 \mathrm{KE}$, and the wetersmons, $105 \mathrm{KW}$.

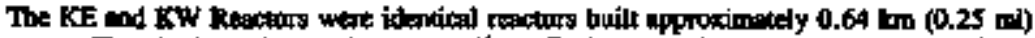

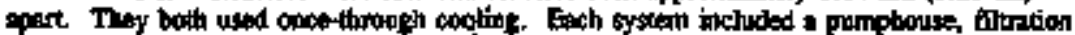
plout, clarweld, combined oatfatr, and a large basin for storing irrodiated fuel. The reactors and thefr suppost tecillies were condructed between 1952 and 1954. The rastors begon

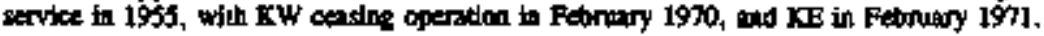

Following shotolown of the KF and XW reactuss, the slored ingatiated fuel wrs shipped to the

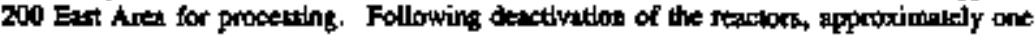

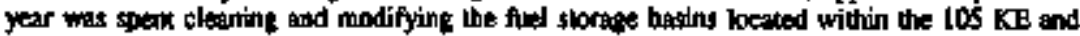
$105 \mathrm{KW}$ fued storage basing for horage of N Reackor irradiated fuel. Addiliond motifications and repairs of the fuel stonge basin system included modiflestion of the becit

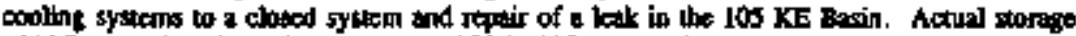

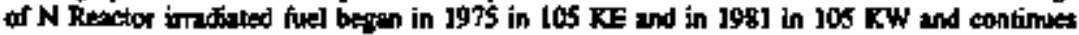
at present. Shipnents of fol to the basins tom N Renelor for storage teased in 1989.

\subsection{FACILITY PHYSTCAL DESCRUPTION}

This FEMP arvets the K Area Fuel Starzge Becint (105 KE and $105 \mathrm{KW}$, the 1706 KE office complex (17106 KE, KEL. and KER), the 1908 KE Oulfall (NPDES Outtall DO4), and

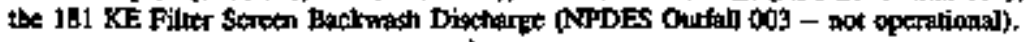

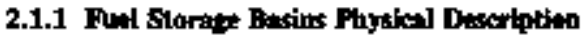

The IOS KE and $105 \mathrm{XW}$ Fuel Storrge Eagins are in mast respects identical. Since fheir consinuction, minor modificetions bave tesulled in slight differencts. The batins are both constructed of reinforced concrete. They are nelarralar, 38 meters (m) (125 feet [ft]) kng by $20 \mathrm{~m}$ ( $67 \mathrm{ft}$ ) wide by $6.4 \mathrm{~m}$ (21 ft) deep. The pools are divided imo three seclions by

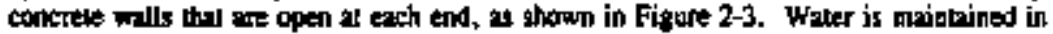
exh balin to a depth ranging from $4.6 \mathrm{~m}$ (15 $\mathrm{g} / 4$ in.) to $5 \mathrm{~m}$ (I6 ft 8 in.) The bouloms of the pools are upproximately $6 \mathrm{~m}$ (20 ft) below grode. Eack basin was modified bo include a recirculation sytem for the besin water inchuding in-line filters, an ion exchange system, a

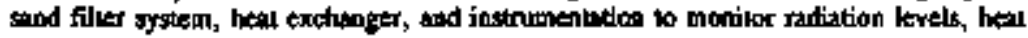


Fieure 2-1. Kanford Silic Location.

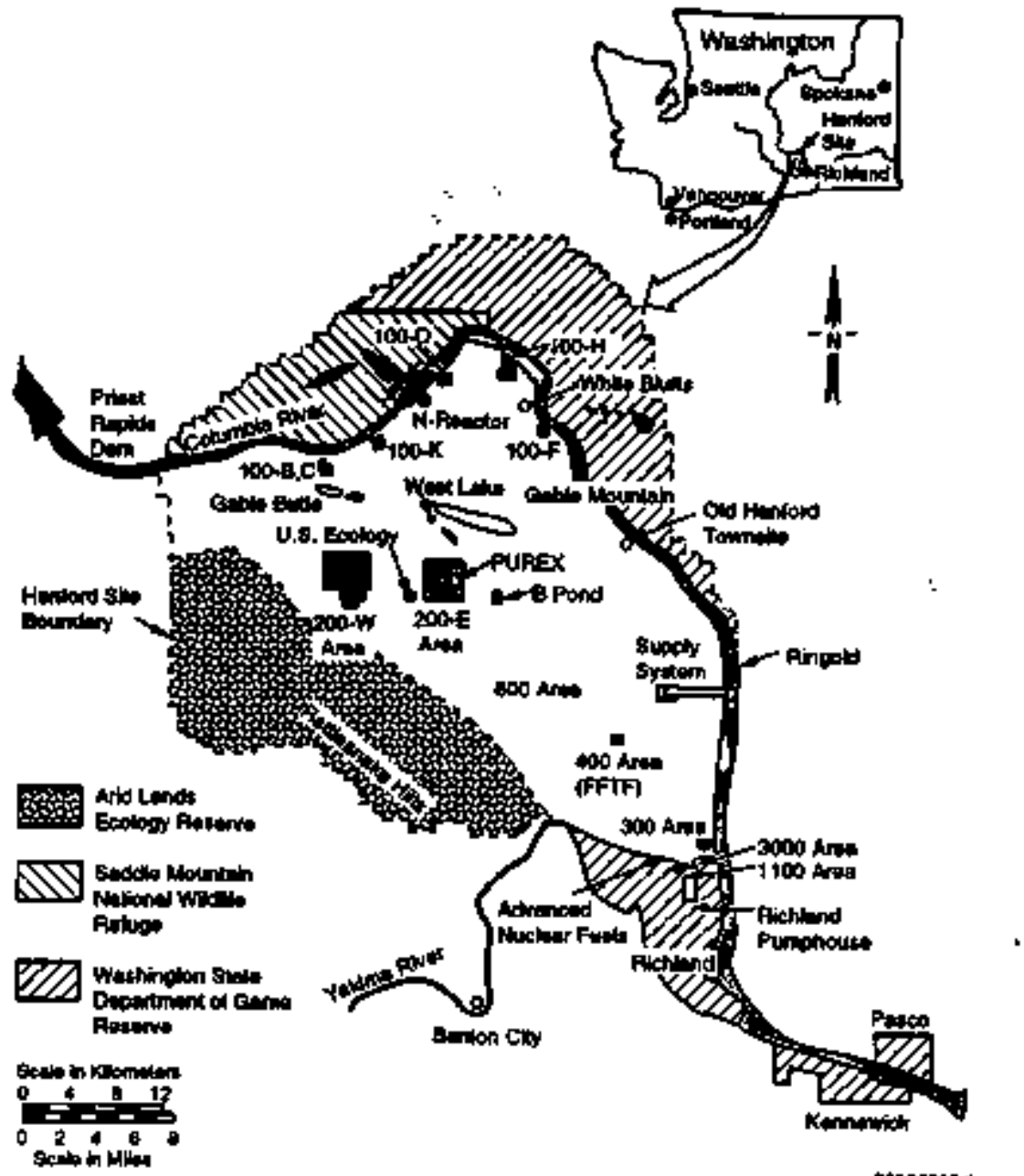

thowrer 
WEC-EP-049h, Rev 2

Figure 2-2. $100 \mathrm{~K}$ Aren.

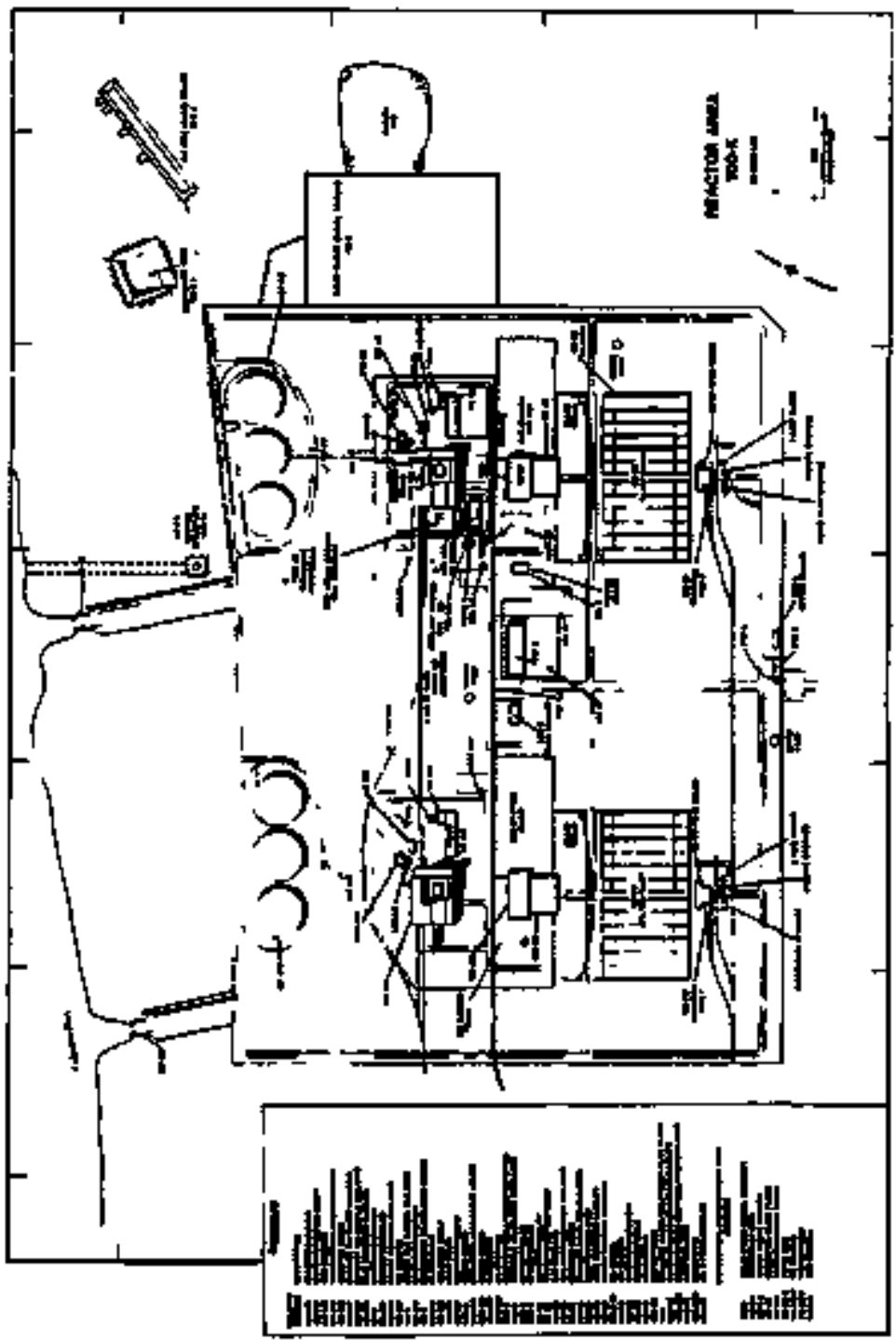


WHC-EP-AK9T, Rev. 2

Fizve 2-3. Fuel Stonge Batus Construction.

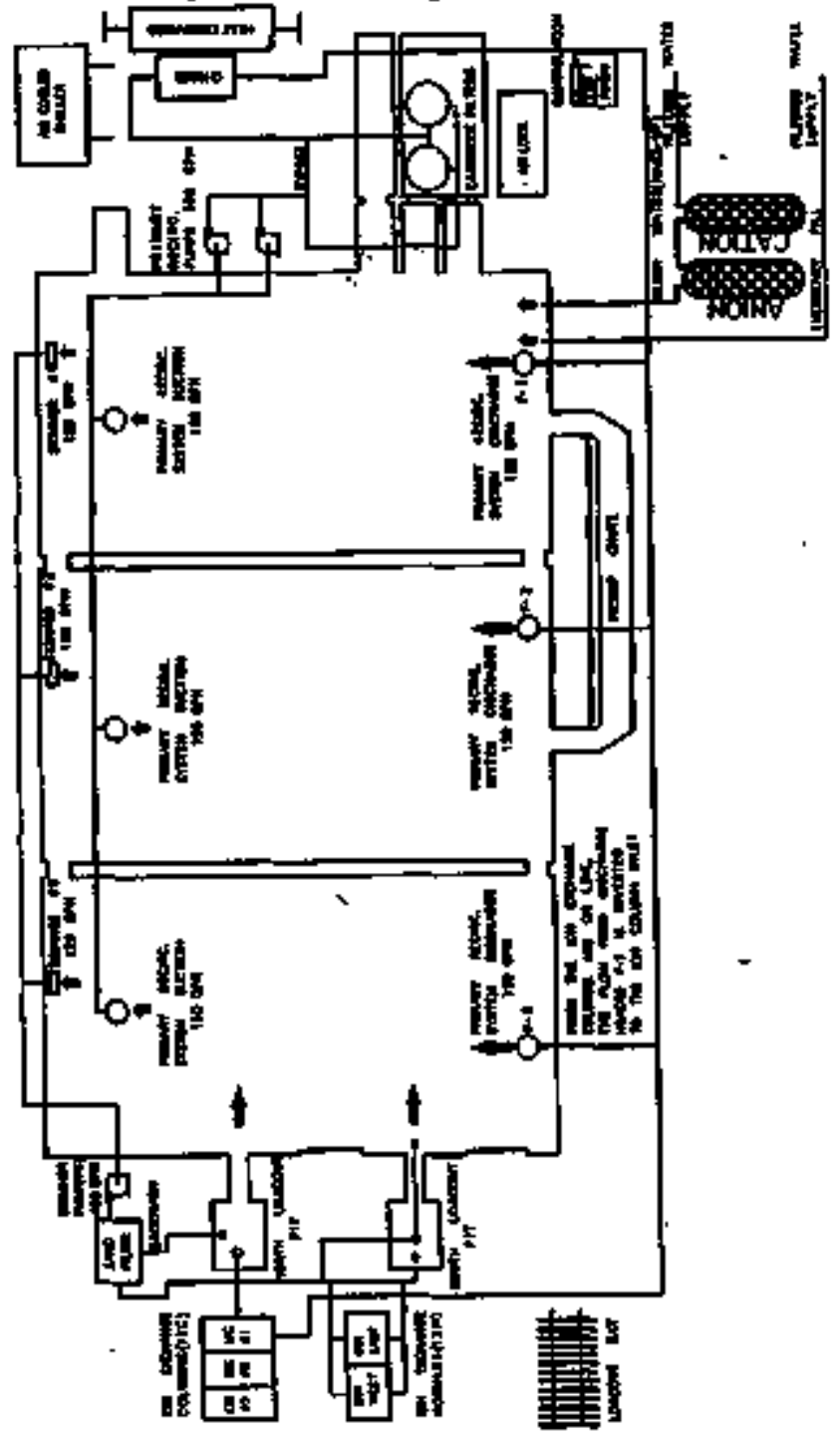


generation rate, and basin waler level. Both basins howe raks inatelled for storing the $N$

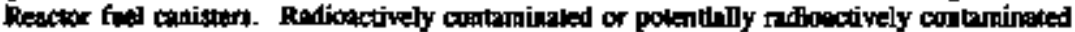

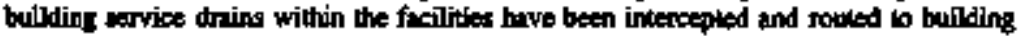

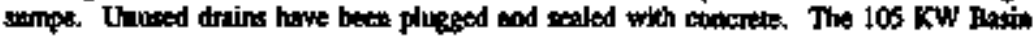
foor and walls were congted with a plinble epoxy cealux, and only encapaulated fuel eniaters are sloced in the besin.

\section{$2.1217 \mathrm{H}$ KC Onee Complex}

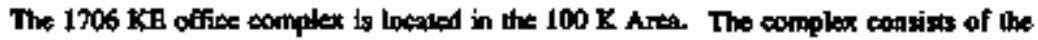
following boildiofs.

- 1706 KE: Office space

- 1706 KEL: Oflice span

- 1706 KER: Storage.

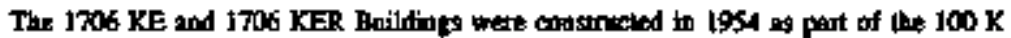
Reactor production sile. The orijinat mission of these facilities was to conduct poilotype slodies on reactor coolant recineulntion cooling gyskens that were tied th the KE Reackr

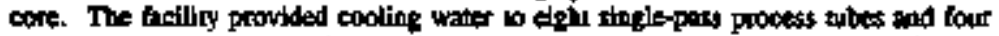
recireulation process tubes in the IOO KE Reactor core. In addition, 22 out of reaclor ted

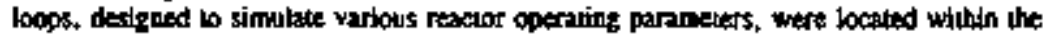

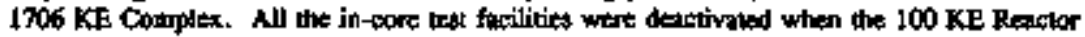
shit down in 1971. All bul three of the teal bops (TF-7, TF-9, and TF- IS) have since been revoroded from the Exilily.

The main floor (0-tt kevil) of the 1736 KE Builiting cotains office space, store rcoms, Junch room, and locter mom, Also bocated an this leved are two test loops (TF-9 and TF-15) and a deactivaled demineralizes plant that once supplied make-op water wa the $105 \mathrm{~K}$ E and J05 KW Fuel Slorage Easins.

The basement [4-it (13-ft] Lvel) of the 1706 KE Bpiliting is mostly oped work trea conbining one test loop, several water ceatment tes units, a reverse ownosil water system, and the in-mastor control room.

The sub-bakement (\$-m [2?-ft] level) of the ITO6 KE Buildims contains deaclivated low- and bigh-prosure pumps that supplied tipht single-pass process ulbes in the $100 \mathrm{~K}$ Reacior eort.

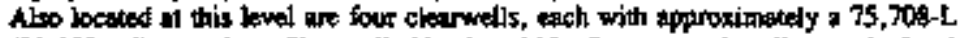
(20,006-gal) capacity. Clearwells ko. 1 and No. 2 were used until recenlly for the 


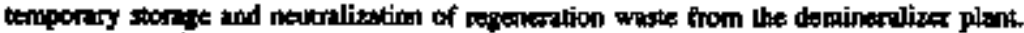

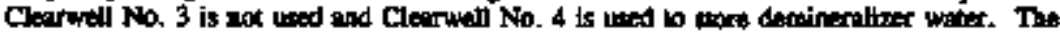

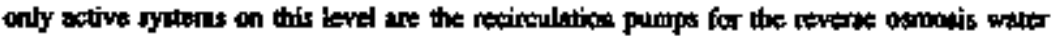
systent.

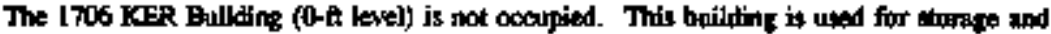
conteins a poction of the 1706 KE Complex switch Eedr.

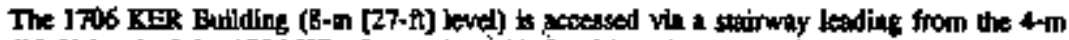

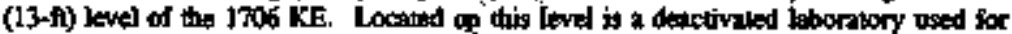

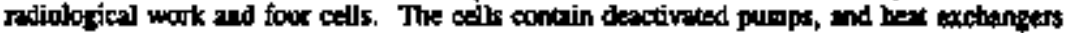

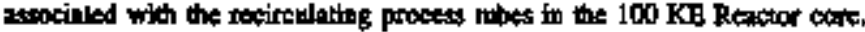

The 1706 KFL Building wes dded bo the 1706 Building in 1961 of provide aftitional

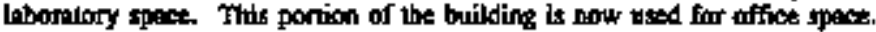

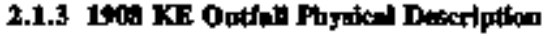

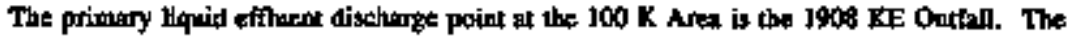

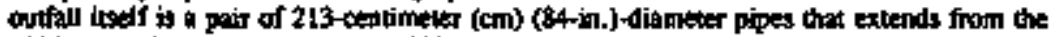

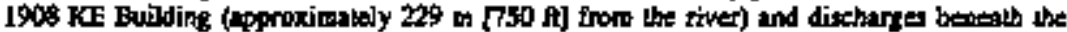
surface of the Colunbla River ore-thind of lie way acoss the river. The oulfall itealf it

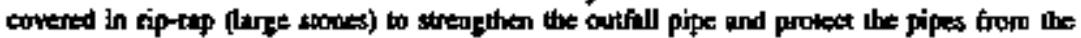
effects of the current.

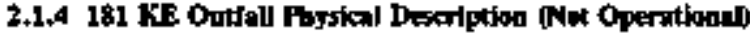

The 181 KE Oulfill is located adjacent to the 1.81 KE Bulloint. The outfall thecharges the tnveling filke xreen backuagh water. The outiol is a 30.4-cm (12-in.) diamekes pipe. It thavels dowmwind fom the fliles screens imto the ground just wert of the 181 KE Hutidimg. The pipe then bends townd the aiddle of the Colombia River. The dixcharge is approxinately $175 \mathrm{~m}$ (575 $\mathrm{f}$ ) toward the eenter of the chantel from the I8I KE Buriding.

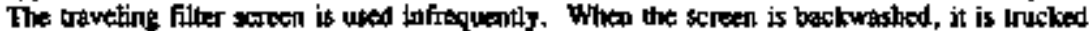
to a gettled basin at I83 KE. Na dischare oxsurs to the Colombia River a्रा present. 


\subsection{FACHTTY PROCESS DESCRIPTION}

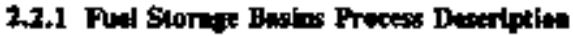

The IAS KE and 10S KW Reactions were shut down th Fetroary 1970 and February 1971

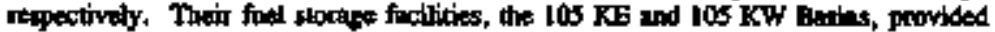
shipstiat and cooliats for the irratialed foet doring opention. In the mid-1970s and early

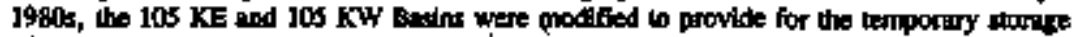

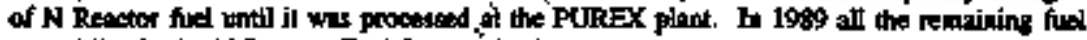

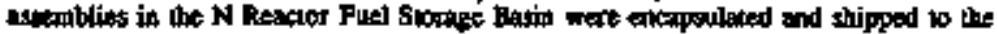
1CS KW Basin.

The 10S Ke Bagin carrently contoins 3,668 open-tep canistare, fillod primarily wilh $N$ Reactor foel, and two bathets (the equivalent of five canisters) filled writh alumimum-chad

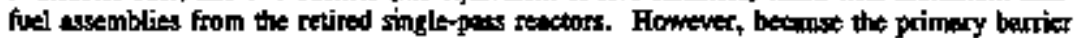
(cladting) of the stoved fucl has been bresched, filsion products have exaped from these tuel assemblies, contuninzing the basin cooling water.

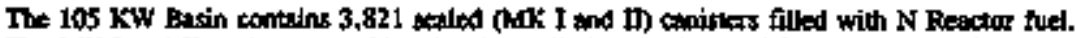
T) MK I and II nistext provide a towier to limil the release of firsion products from the danaged fuel assesublies, and the besin cooling water prowides a secondery barrier so the polential relewe of adtosetive makerials on the enviromment.

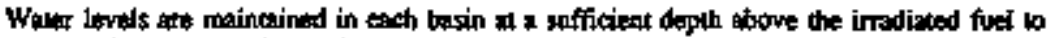
oogl the fuel und provide radiological shielding fur personnel wurking in the fecility. Filkers and ion exchange syghons maintain basin water clarity and remove radronuclides.

\subsection{KE DIfike Complex :}

1706 KE office oxmplex fecility was originally designed as a terting complex. This

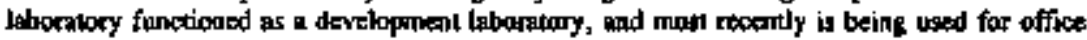
ipace.

\subsubsection{4: KE Onafin Process Description}

Efluent to the 1908 KE Outfall comes from kour sources. The firs (and largest) of these

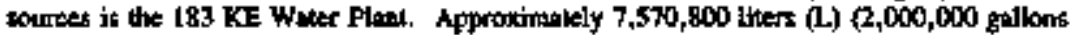
(toil]) of river wale pet tay are cycled through the 183 KE Basto for fith rearing and back to the Columbia River. The socond effluent source in the filien backwagh trom J83 KE, which goes to a selling basin and then, after setling, to the outfoll. The only cbemicals 


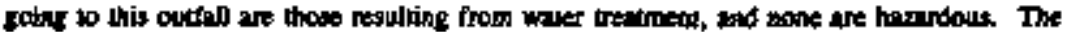

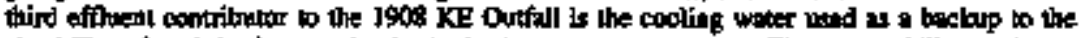

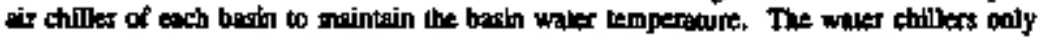

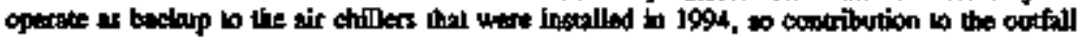

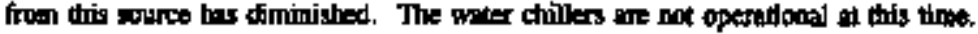

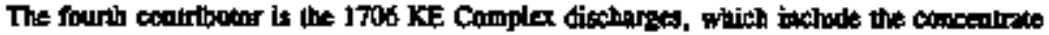

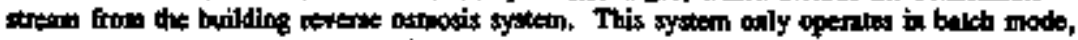

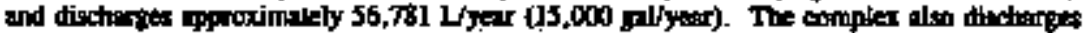

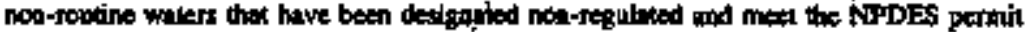

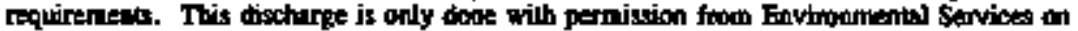

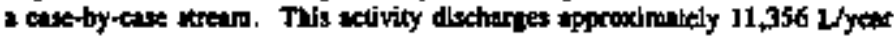
$(3,000$ paidyerar).

\subsubsection{KE Outholl Process Descripiloo}

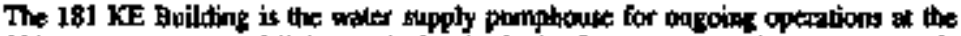

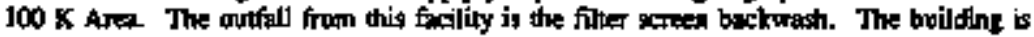

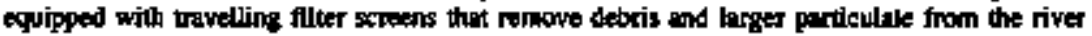

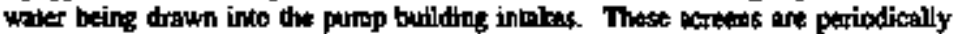

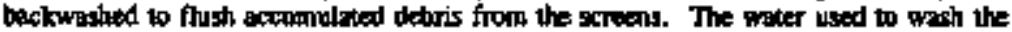
sereens (when they ure operational) to then ntumed to the tiver via NPDEs Oulfall 003 .

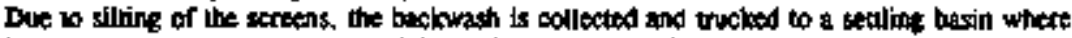
it is evaporald. There is no possibitity of the dixcharge trom this outfall conlaining radionuelides or contoniants from operations in the $100 \mathrm{~K}$ Arta.

\subsection{IDENTIFCATION AND CHARACTBRZATION OF FOTBNITLL SOURCE TERMS}

\subsubsection{KE Fuel Slonge Busto Sowree Tero}

The KE Basth conteins approximakly 1,150 meric kms of trredlaued tuel.

\subsubsection{KW Fuet \$tarate Busin Somato Torm}

The KW Basin comtrins approximately 956 metric tons of irradiated fuel. 


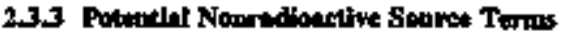

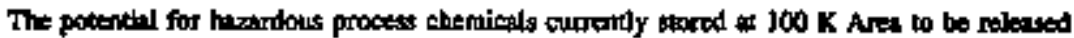

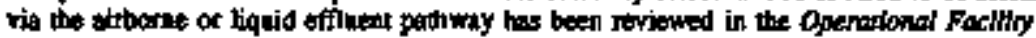

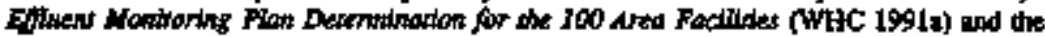

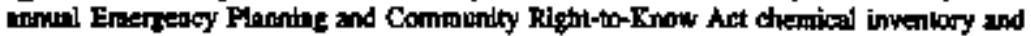
release reports. This review has devermined that thate is intignificant polentivl for these

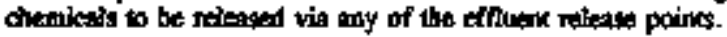

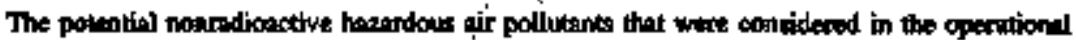

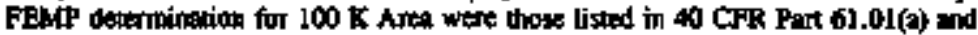
40 CPR Fart 6I.(0)(b). [1 was determined, stier a thorough rovizw of the 105 XEXXW Operating Fanditites, that none of the chemicals lisied is elther 40 CFR Pun 61,0](a) or (b). with the excoption of radionuctides, are presont is the airbone rateses from 105 KE or KW. Therefore, sadionuclides are the only horerdous air pollotank considered in this Fer.P.

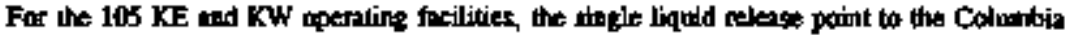

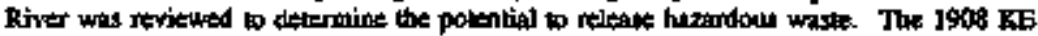
Outfall and 181 KE Oulfall ate perniled NPDES oflifals, and the analyaid perfirmed on

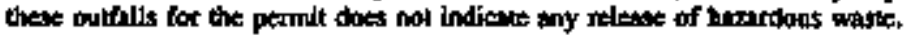

There aro no other harardous waste matrials released by $\mathrm{KE}$ end $\mathrm{XW}$ operaing tacilities via either the air emiggions pathway or the liqnid effluent pathray. 
WHC-EP-0497, RN. 2

This parge intendionilly len blant.

$-$

3

\subsection{0}




\subsection{APFICABLE REGULATIONS}

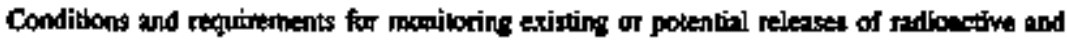
other chemicals to the envirooment are contined in DOEE onders and federal, wer and locel

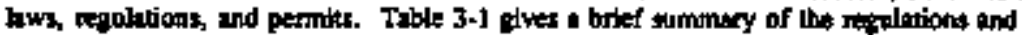

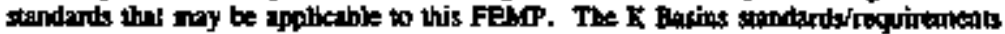

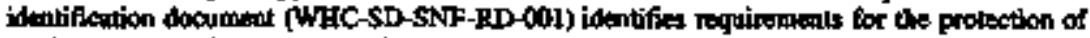
wroters, the poblic, and the enviranipent that apply to K Bestins.

\subsection{U.S. DFPARTMISNT OF ENERGY ORDFRS}

\subsubsection{Cenerl Entroencental Protection Propram (DOE Order 5400,1)}

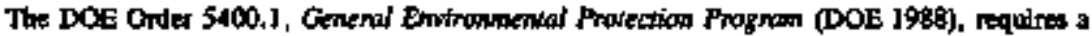

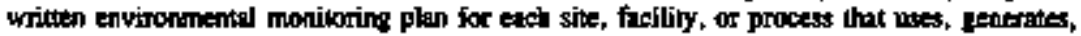

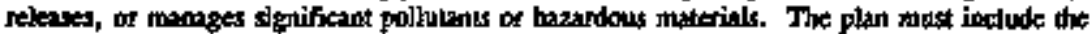

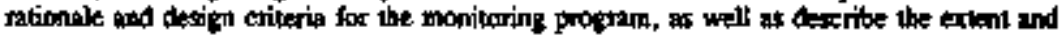
frequency of the monibating andysis. The plon also must conala quality assumance

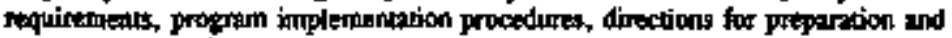
implementrion of zeyouss, and directions for identifying and discussing efluent moalenting and enviroamental surveillares.

The effluent matiloting portion of the plan musd vetrify compliande with applicable resulations and DOE onders. It also thould: (1) evaluate the effectiveness of trealment; (2) idantify potential anvironmental problem:; (3) ovaluste the nood for rentedial action or miligation measures; (4) support permit'revirton andy ot relssunace; and (5) defíne a

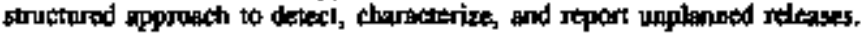

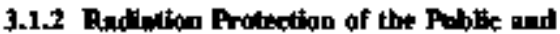

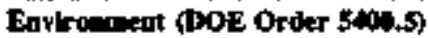

The DOE Ondert \$400.5 (DOEE I990h) requires a monivorine plan that tomplies with the requirements of DOE Order $\$ 400$. I (DOE 1988). Cormpliapce with the requirorants of DOE Onder 5400.5 may be demonstrated bosed on colcubtions from monikring and gurvitlanoe profram information. 


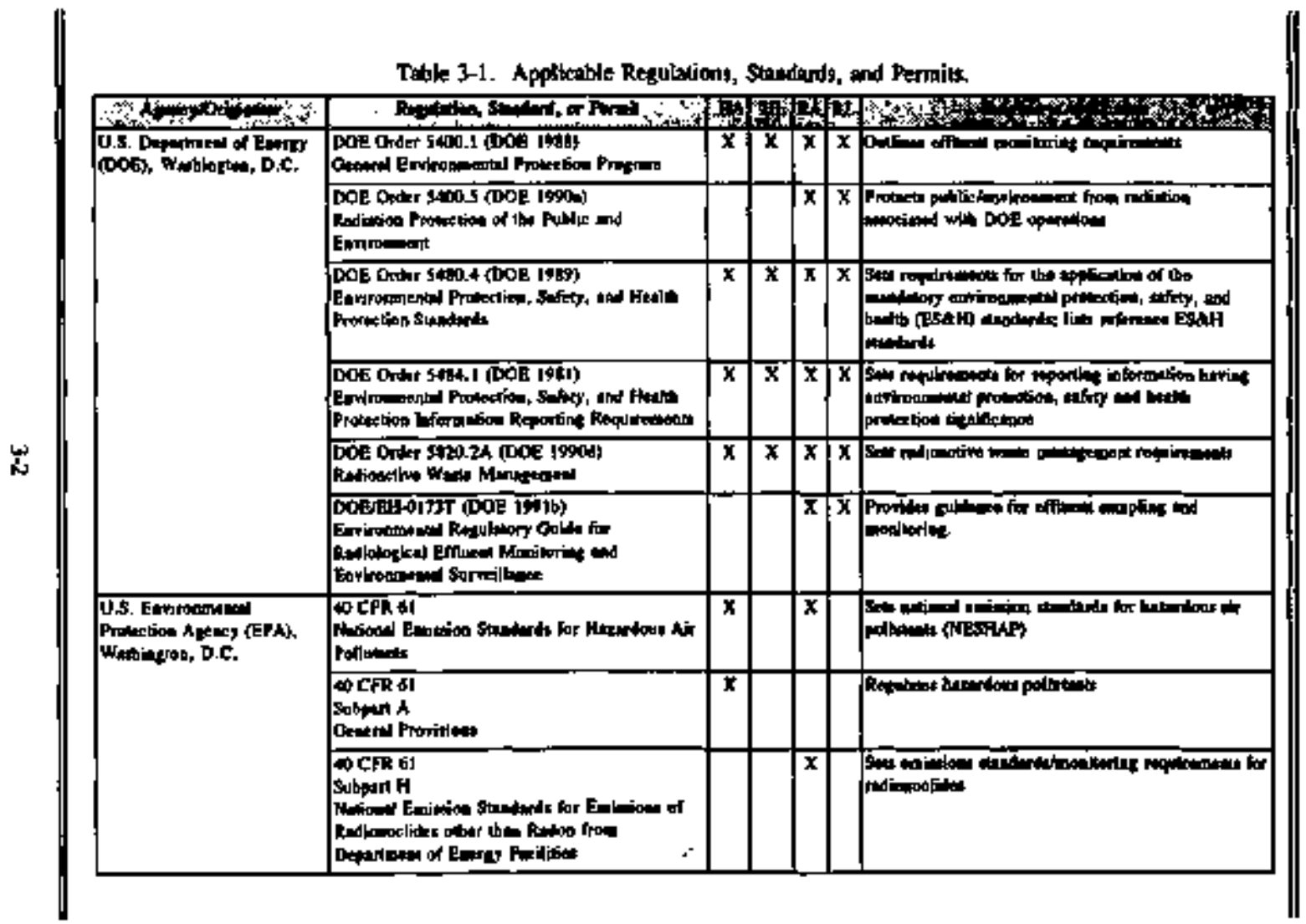


Tabie 3.J. Applikcable Regulationt, Standards, and Prmits.

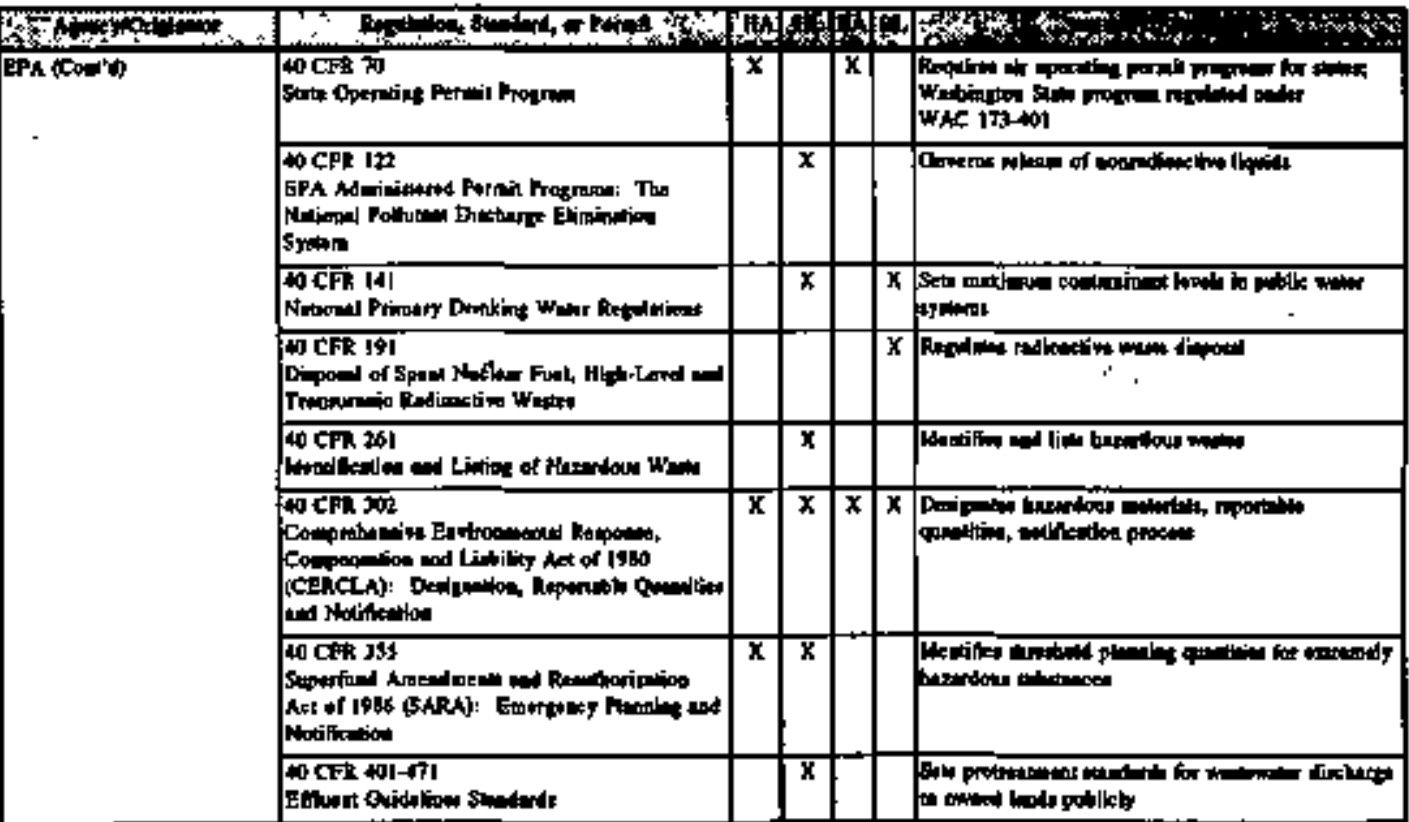


Tatle 3-1. Appticable Regalalions, Standands, and Pernits.

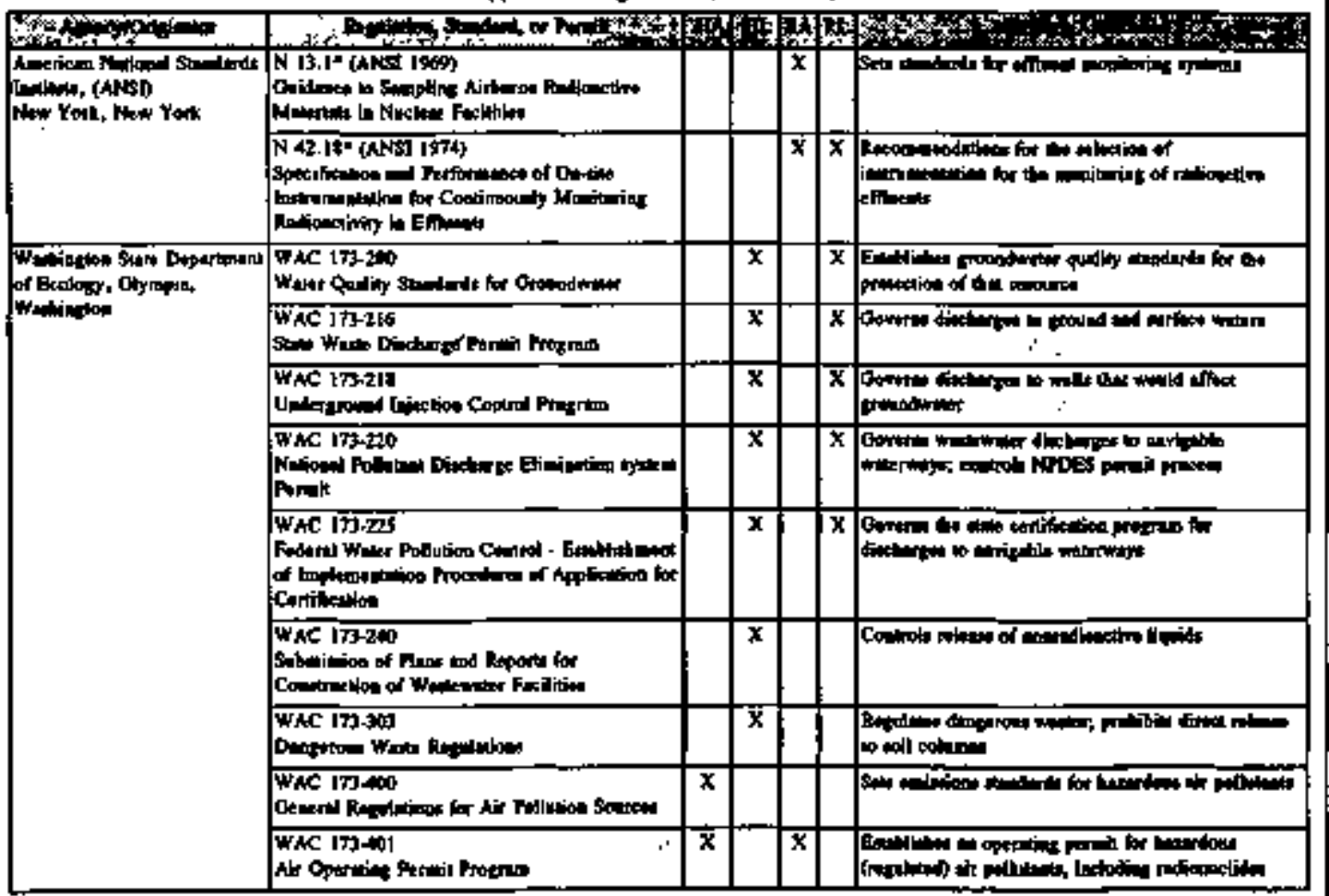


Table 3-1. Appticable Rezulations, Sandards, and Permits.

\begin{tabular}{|c|c|c|c|c|c|c|}
\hline \multirow[t]{2}{*}{ 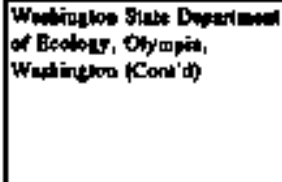 } & 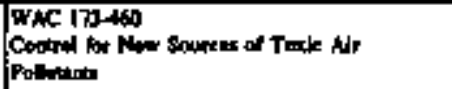 & $x$ & & & & 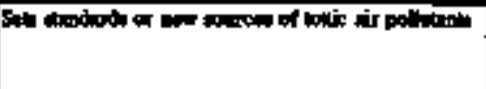 \\
\hline & 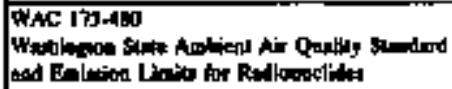 & $\overline{\mathbf{X}}$ & & $\overline{\boldsymbol{K}}$ & & 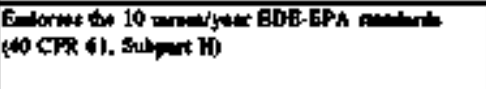 \\
\hline 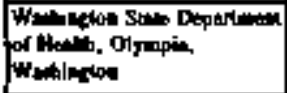 & Pach 246-247 & $x$ & & $\overline{\mathbf{X}}$ & & 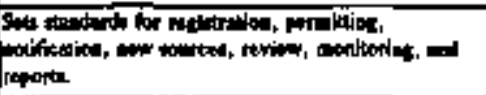 \\
\hline 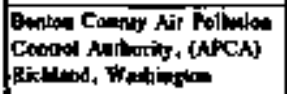 & 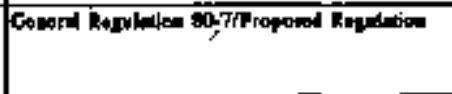 & $\overline{\mathbf{x}}$ & & & & 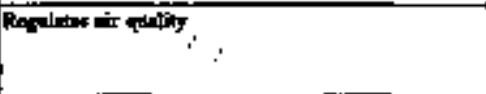 \\
\hline \multirow[t]{4}{*}{ 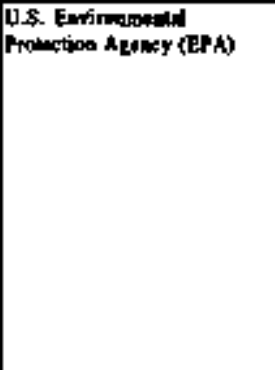 } & 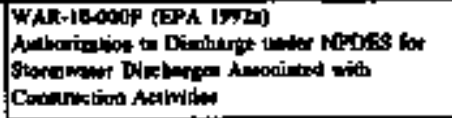 & & $\mathbf{X}$ & & $\boldsymbol{X}$ & 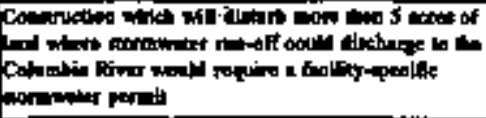 \\
\hline & 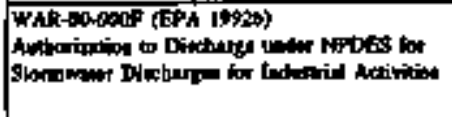 & & $\mathbf{X}$ & & $\overline{\mathbf{x}}$ & 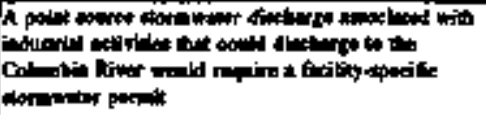 \\
\hline & 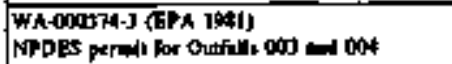 & & $\mathbf{x}$ & & $\overline{\bar{x}}$ & 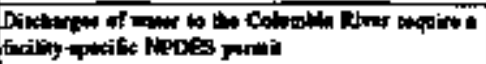 \\
\hline & 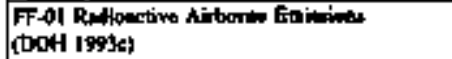 & & & $\mathbf{X}$ & & 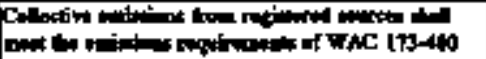 \\
\hline
\end{tabular}


Table 3-1. Applicable Regulations, Sunderds, and Permits.

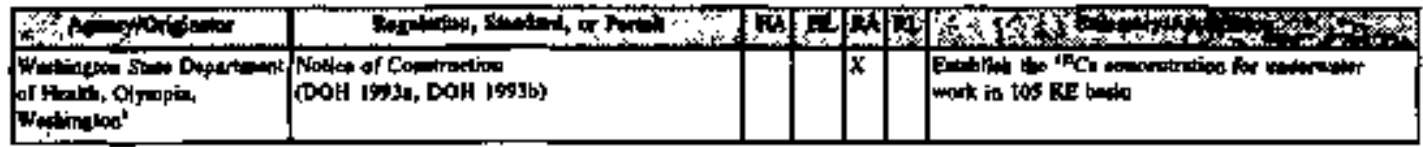

Non:

HA = Magardos alrborm.

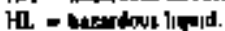

RL - racinecalud Pridid.

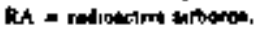

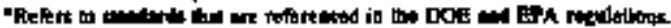

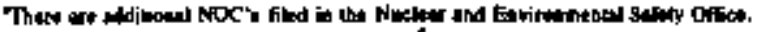


WHCC-EP-0497, Rev, 2

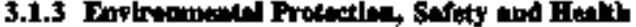

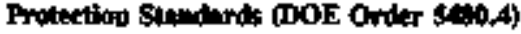

To specify und provide requirenterits for the epplication of the mendstory environnented protection, safety ind heahh (ESkH) sundurds uppitcablo to all DOE and DOE conbractor

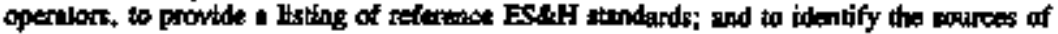

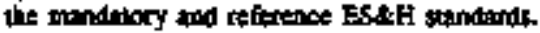

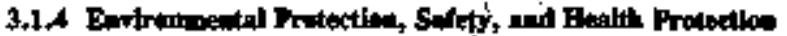 Informatie Reportimg Receireme-ts (DOE Orida S44.1)}

This order efablabes the requirements and procedures for the invertigation of oculreences

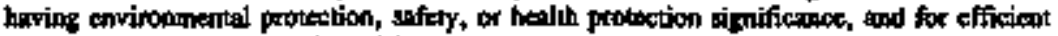
and envirinmestal monitoring of DOE opertions.

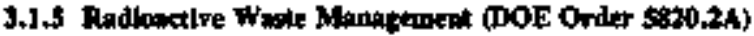

To estrblish policis, guldelines, and mintmum requirements by which the DOE manages its rwdipective and mixed waste ond contaminated facilitis.

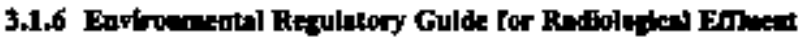

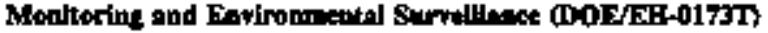

The purposs of the repulatiry guide is to ppecify the noceationg tkements for effluent

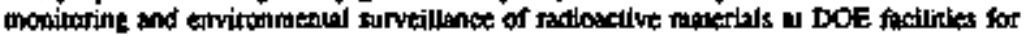
cormpliapse with both applicsible foderal regalations and DOE poticy.

\subsection{FEDERAL REGULATIONS}

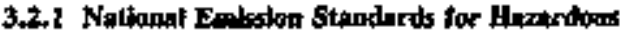 Air Pollutants $\{\$ 0$ CFR \$1)}

Subpart H, "National Emiserion Standards for Enisuions of Rudionuclides Other Than Radon from Department of Encray Factlitles," esablishes exposure limits and Inonhoring requireanents. The expossure limits, for mentbers of the public, from radicmuclide entrissions is an EDE not to exceed 10 mrenfyer. Compliance with this sandard is measured by calcalatipg the higkes EDE whete a perkon resides or abdes using an EPA-approved method. 


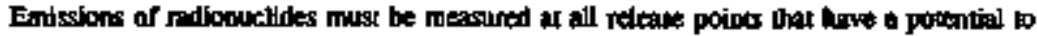

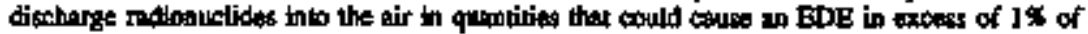

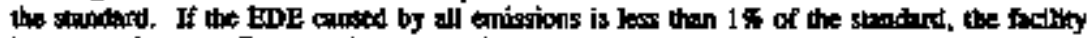

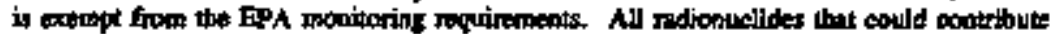
greales than j0\% of the potentiol EDE for a release point ghall be meatured individatly.

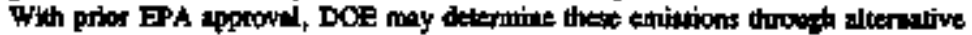

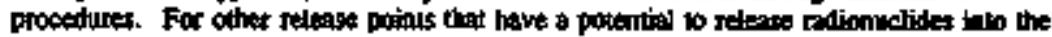

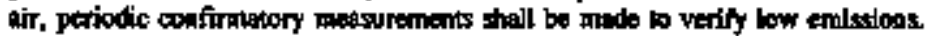

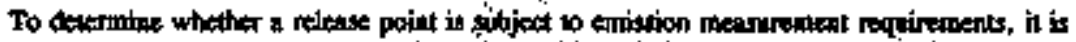

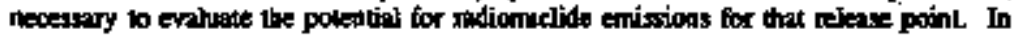

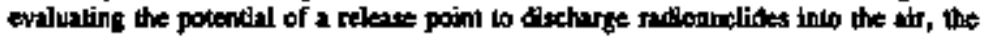

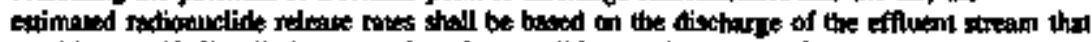

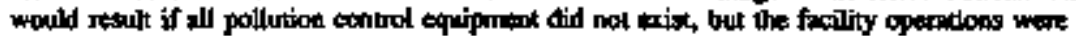
of therwis nomitr.

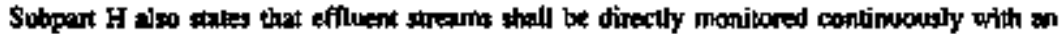
in-line detector or represealiotive sumples of the effluent tream shall be withdrawn continuousty from the manpling site followipg the guidasce presented in Anericon National Standerds Intthus (ANSI) N13.1 (ANSI 1969). The requinenerts for continuous ampling

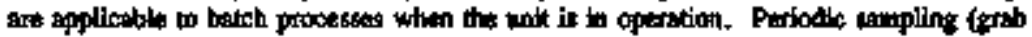

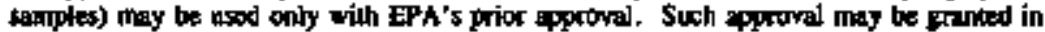
caves where continuout enrpling is nol practical and radionuklide enistica rites are :

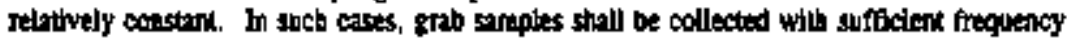

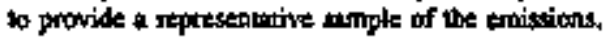

\subsubsection{State Operatho Permin Program t40 CFR Th}

This regulation defines the mirimum eltements required by the Fedenal Water Poldation

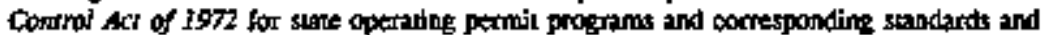

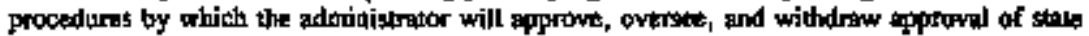
operzating peruil proerims.

\subsubsection{EPA-Ad!-latered Perlt Frogras The Natopal Polutant

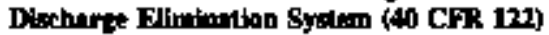

This refulution cotvers batic EPA petinitaing requthements and procedures for EPA processios of permil appliations and appeals. 


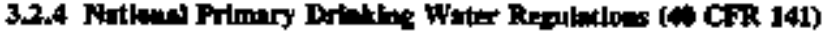

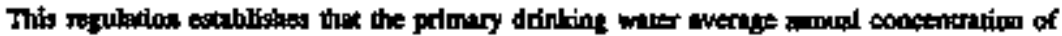

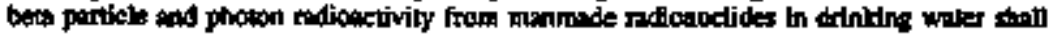

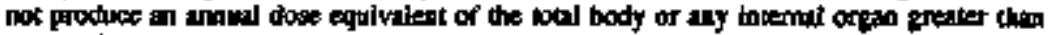
4 matsyr.

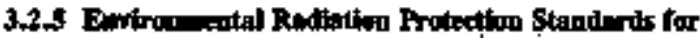

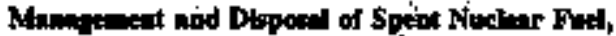

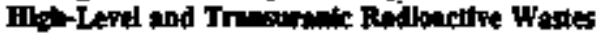 (4 CFR 191)}

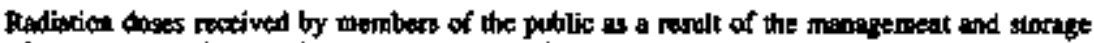
of ment mucker fuel or hiqh-level or trinsuranic ndionetive waskes at any tacllity shall not exceed 25 arem to the whole body, 75 mrem is the thyould, and 25 muth to any other critical orgath.

\subsection{6 beatifeation and Uatine of Barerdous waste (49 CFR 261)}

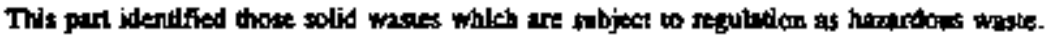

\subsubsection{Dedigarilow, Reportable Oenut*iles, and Net'iculos (45 CFR 303)}

The regulailons to -EPA Destgnation, Reportable Quandides, and Notification Rexuitements for Hazardous Subsionces Under CERCLA" (10 CFR 302) desiznate harardous subutanoss and identify reporteble quantities and notification repunrements for telease of these hazardous

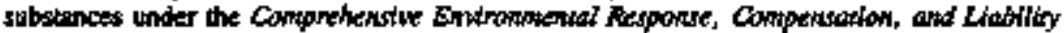
$A C$ of 1980 (CERCLA) and the Sofe Drinking Water Acr of 1974, at amended.

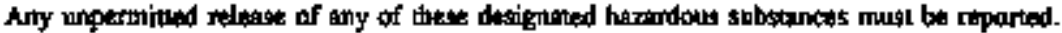
Therefore, if the possibility exists for a facility lo release any of the designrated substances.

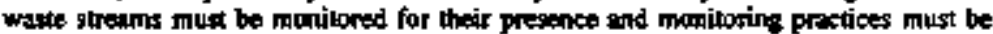
provided in a FEMte.

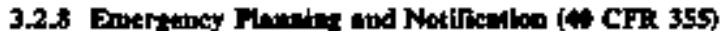

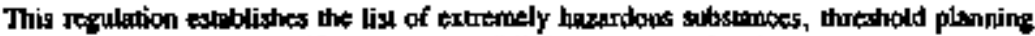
quantities, and facility notification respoesibilities nexessary for the development and

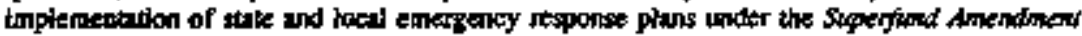

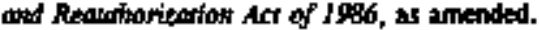




\subsubsection{Ement Gubdellos Standands (40 CFR 401-47)}

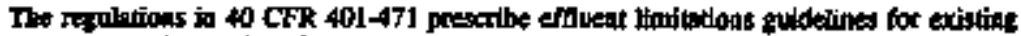

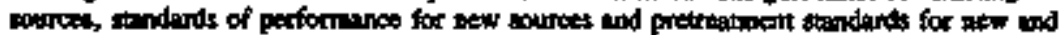

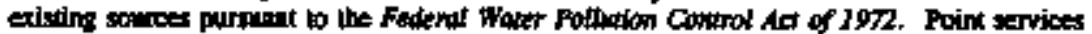

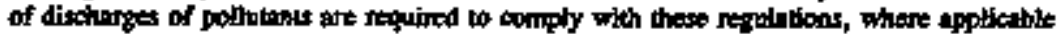

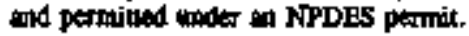

\subsection{TTOUSTRY STANDARDS UNDEX AMTERICAN NATONAL STANDARDS INSTITUTE}

\subsubsection{Culde to Sampling Alturre Radluative Mnterials

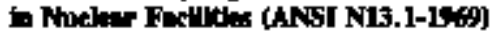

The primary otjective for samplint aitbome radiostivity in effluents is 10 measure the

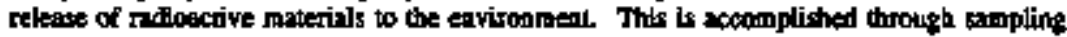
near the point of noless.

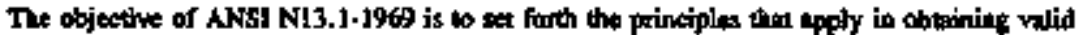

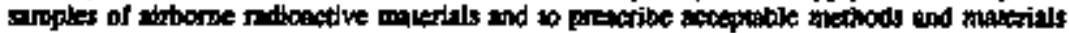
for poesins aed particulate satipling. ANST N13.1-1969 is timited to the collection of :

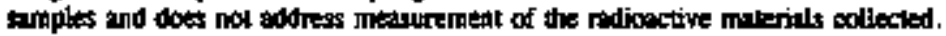

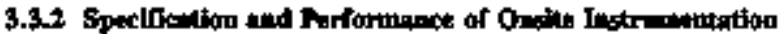

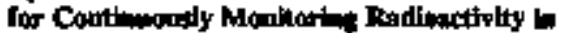

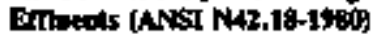

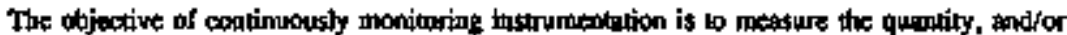
the rate of releate of rationpelides in the effluent streard and kp pervide useful docophentation for scientific and kggical purposes.

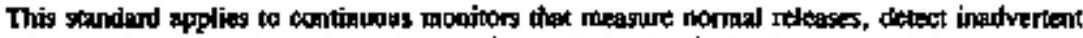
releases, show generil trends, and ennunciate ridiation levels that have exceoded predetermined valuos

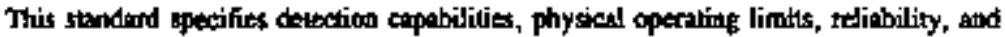
esibration reguirements and sets forlh minimum perforatanke requirements for effhuent monioniog. 


\subsection{WASHINGTON STATE FEGULATIONS}

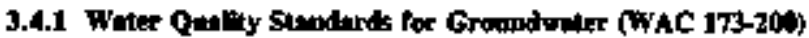

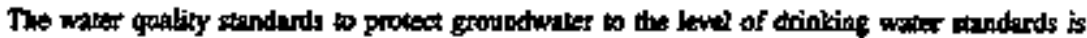
contined in Whar Qualliy Stundrods for Groundwates of the State of Whaningtos

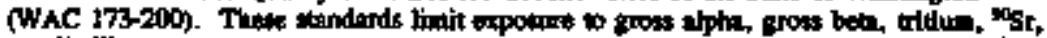

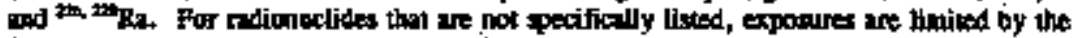
foderl stondard to an EDE not bo exced 4 mremityer:

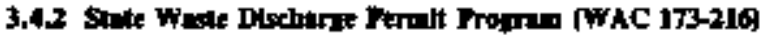

The purpose of this shte requlation is to inplersent a Inte permit program, applikeble to the discharge of whste materialy from industrid operstions lato cround and sarboe wates of the

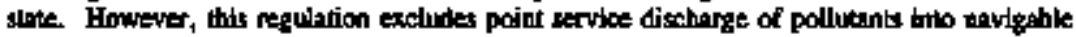
waters of the state, which is regutaled by the "Notional Pothutad Discharge Blimination System Permi Proftem" (WAC 173-220). This tegulation alson exelndes the injection of

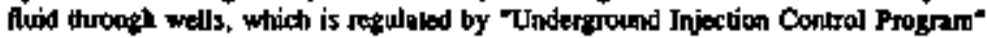
(WAC 173-218).

\subsubsection{Undergroned Injection Coatrol Program (W/AC 173-218)}

The porpose of this regulation is to set forth the procedures and pretices appltable to the injection of thaid through pells. The disposel of wrske flulds from indurtial worts into

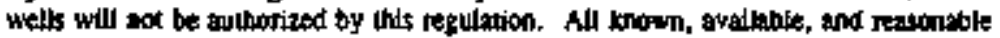
methods bo mevent and control the dischare of fluids and wase floids inb the water of the sthe will be rectulated.

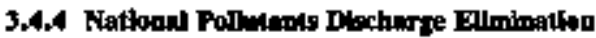 Syates Pormil Projram (WAC 173-220)}

The purpose of this itguladion is to esuablish a state pernit program. appliceble to discbarge of pollutanis and other wastes and makerisls ko the surface waters of the stake. WAC 173-225 estoblishes the sute certifleation progrint for implementalion of the Fedend Woter Foltumian Comirol Act of $\$ 972$. 


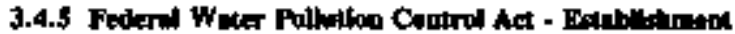

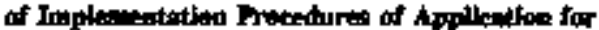 Certifionlap (WAC 173-225)}

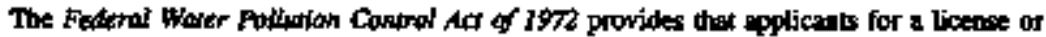

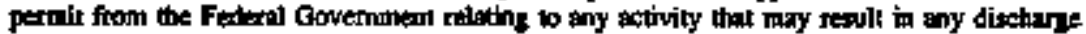

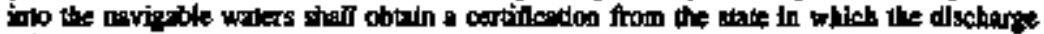
oniginave. The purpose of this negulation is to establish procediuts for putitit aotice and

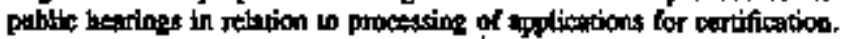

\subsubsection{Stbristion of Plans and Reports for Cenotraction of Wustomier Facllikes (WAC 173-244)}

Prior to the eonstruction or modification of wrytowner facilities, enfinesing reports and plans and spectfiestions for the project shall be subritited to and approved by the state.

\subsubsection{Dangaroses Wade Regulalons (WAC 173-303)}

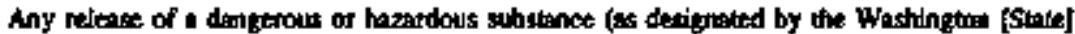

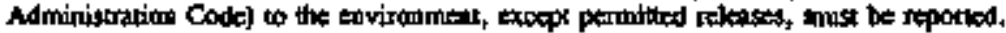

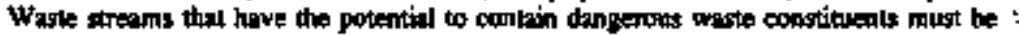
monikored accordingly.

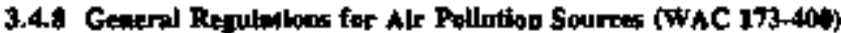

It is the policy of the Wastingtos Stule Depanment of Eoology to provtde the syctemastc

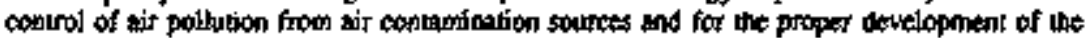
Strive's naturnl resounces.

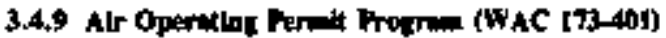

The peravitions in thit requlation establtah the themenl of a comprehensive Washington Stare air operatidr permit progran consisteat with the requirenkents of the Fedent Clean Air ACt of 1977 . All pounes (haresdous and adionselides pollotants) subject to this regulation ahall have a permit bo cperne that assures complianoe by the senice with all appliesble requirements. 


\subsubsection{Cootrab for Now Sources of Twade} Atr Pollutouts (WAC I73-460)

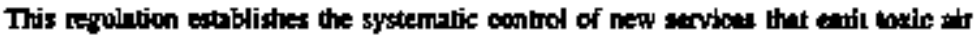

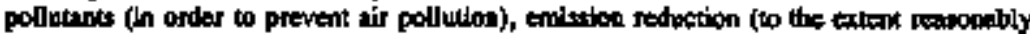

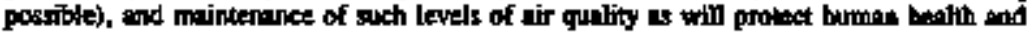

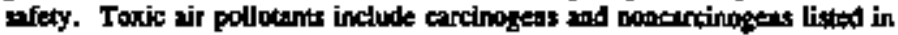
WAC $173-460-150$ and $\mathrm{JT}-460-160$.

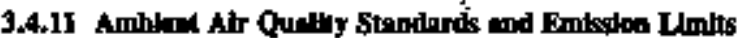

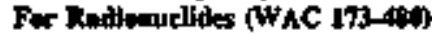

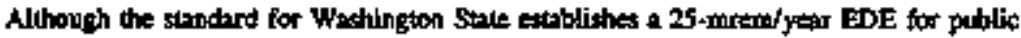

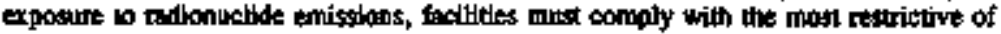

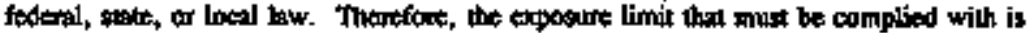
10 morla/year, however, complisince is colculuted at the poial of maximam moual air

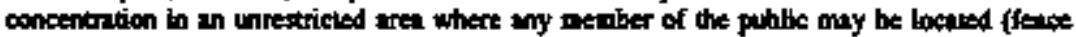
boundery).

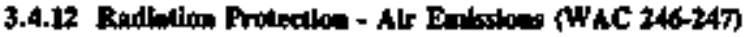

This regulation spectifiel new source rewew, octifcation, refistrition, and permitting

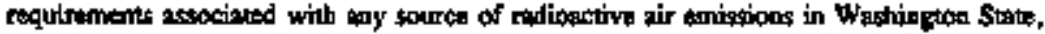
tncluding those os the Hanfand Site. One requirement listed in WAC 246-247 is the

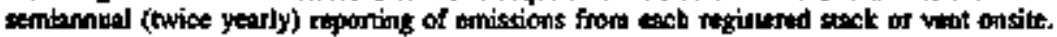

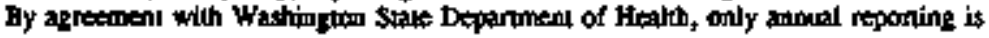
required.

\subsection{LOCAL REGULATYONS}

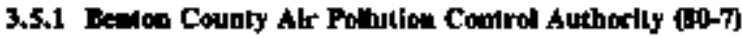

The locel air pollution conurol authority has jurtadktion over all air emissions excepk

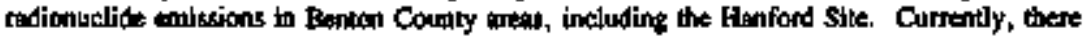

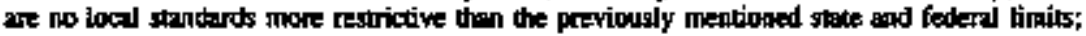
therefore she and jederal staptants apply. 


\subsection{FERTtS}

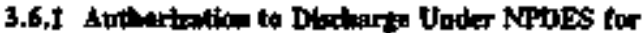

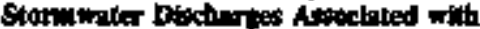 Comstruction Adritle (WAR-16-WOFHERA 1992n)}

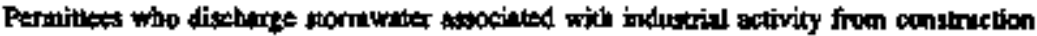

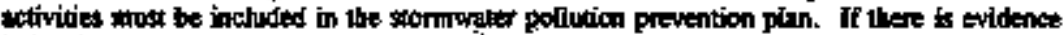

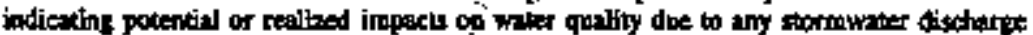

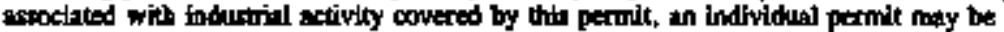

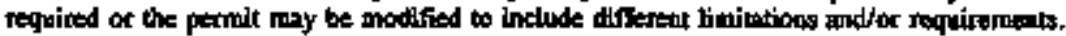

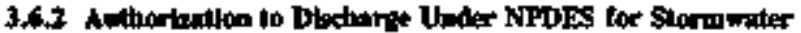

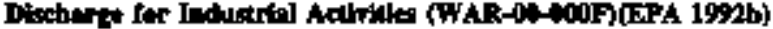

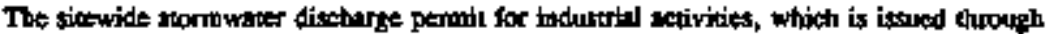

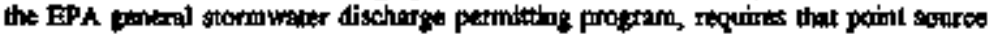

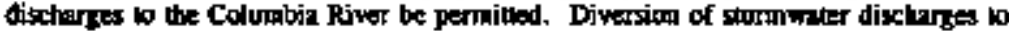

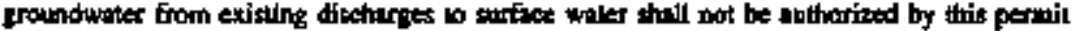

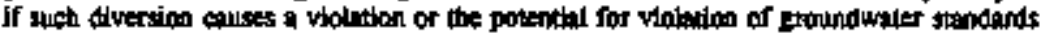
(WAC 173-200). Dissharges below the turface of the pround anc also regulated by the Undergersund lnjection Control Progrnm (WAC 1T3-218).

\subsubsection{NPDES Permit (WA-400374.3)}

The permittex must comply with all condlutens of this permit Any tembil noncomplance

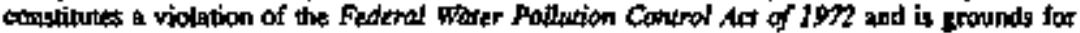
erforcentent action. The permittee sholl give notbe to EPA, as soon as possible, of any planned physical allerations or additlons to the permitted facility. The permittec thall also give advanee noties of any planned changes in the permitted faciltity of activicy that may resull in toncompliance with permlt requiremets.

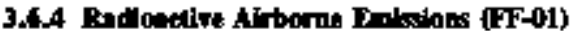

The collective emisvions from all regiskesed soarces fron all aras on the Sile stall meet the emitssion tequimements of WAC 173-400-040. The department shall be notified of any source

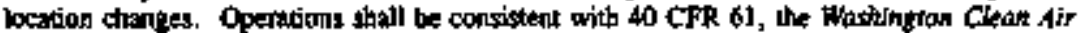
Act of 1967 (RCW 70.94), aed WAC 246-247. 


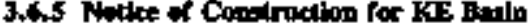

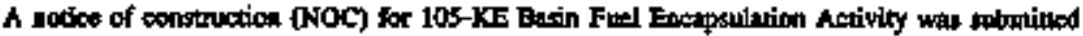
to the Wabington State Depertinent of Heallh purstant to WAC 246-247. The NOC

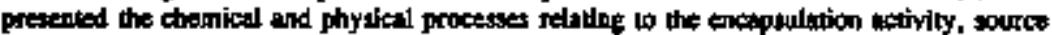

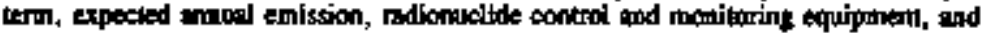

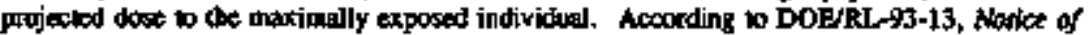

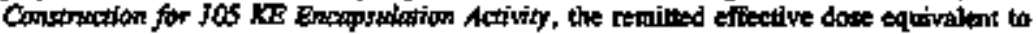

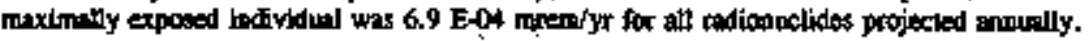

This NOC has been amended by the Wasington Stole Departineax of Fealth for olher

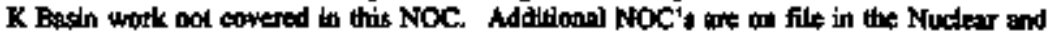
Emironmentrl Safety Oftice.

\subsection{AR EMTSSTON'S}

DOE Order 5400.5 (DOE 1990a) provides requiremeols for the monitoring of tadipactive and Donradionetre nibome effluents from DOE factities at the Hanford Slite. This order

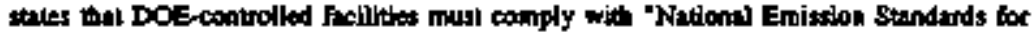
Hazardons Air Pollotints (NESHAP)(40 CFR 65).

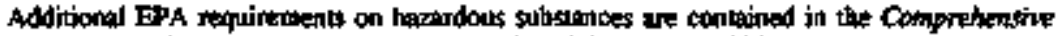

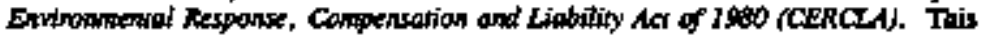
tapulation prowdes tnformation on repoctable quantitios of tadionetive and aonradipactive

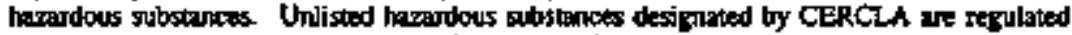
in accordence with the EPA loxicity of the contaminanl.

In Wrshington State, airbome offluents are regulaled by the Wroshingtan State Department of Ecobogy through regulations in the WAC, Title IT3, Chapters IT3-400 through 173-4B0, 2s anterded, pursuant to the Washington Cleas Air Act of 1967 (RCW 70.94, as antended). Generl regulations for air pollution sources are pesenled in WAC 173-400, iachuding emission standards for soures temdting harardous ait pollutanls found in WAC 173-400-075.

WAC 246-247, "Radiation Protection htr Emisions," specifles new source revkew,

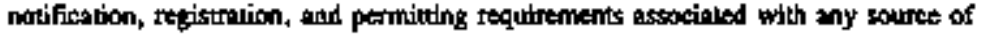

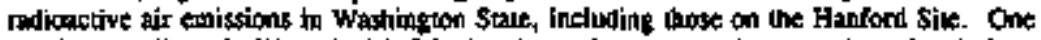
requirement listed in WAC 246-24? is the biandual (twice yearly) riporting of earizsipns from each regiskered stack or vent on site. By grgecreent with the Washington Snte Departmenl of Heath, only ennul reporting is required.

WAC J73-460, "Ambient Radiomultdes," defines maklmum allowable levels for radionucltdes in the ambienl air and defines required levels for control af emiszions. 


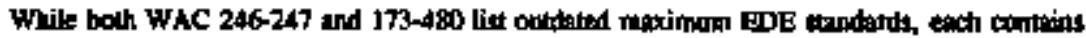

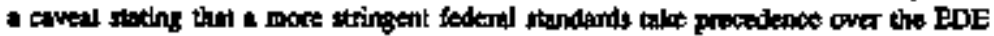
thindard apecified by the WAC. Thatione, oftectively endorses the 10 mrem'yen EDE standard of "Natbonal Enistion Sundarta for Hazadous Air Polhotita (NESHAP)" (40 CFR 61), Subpart H.

Regulationg, including DOE odtan, ste that DOE facilities most comply with the roqulteroents (NESHAP) (44 CFR 61). OHer regalations (e.t., 40 CFR 52, "Appoinl and Promulontion of Implenkoution Pland"; and DOE Onders S400. I (DOE 1986n), 5400.5 (DOE L990), DOE'EH-0[73T (ONE 19916), and 5464.1 (DOE l981) the that DOE fallider must

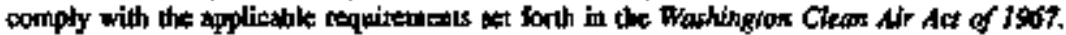

\section{A LNOUD EPRLEWTS}

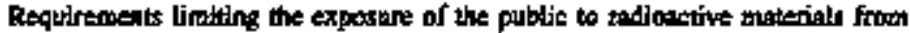

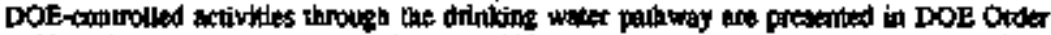

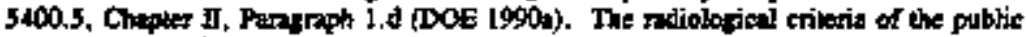

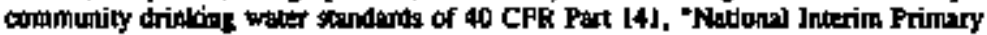
Drinking Water Reoulations," aro applicable to 183 KE Water Pint as the prowider of potoble wales in $\mathrm{K}$ Aner under the Saft brividng Woter Act of 1974. It th the policy of DOE to provide on equivalent level of protextion for all persons consuning wrter from a dinking

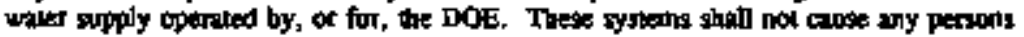
consuming the werer to recejve an EDE grester than 4 aremlyear, excluding mistlly occurring radionuclides. In addition, DOE feelithy opentors thall ensure thal the liquid

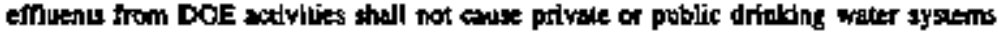
dowastream of the facilily discharge to exceed the dinining water rodklogical limits of 40 CFR Part J4l.

Dependtag on whene a lkquid efiluent (waskewaber) is discharged, cerbin regolations apply. These regulations are intiplemonted through issuance of permits by federai, state, andior local agencies. It is the responsibility of the facility, throwgh the Richland Operations Office (RL),

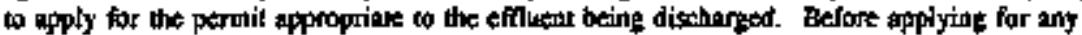
permits, the applicant mus lnow the source of wastewaler dixhroges and where the wastewaiker is beine diveharged to. 


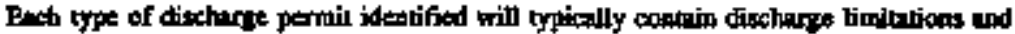

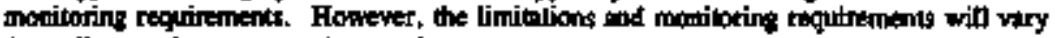

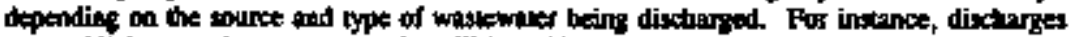

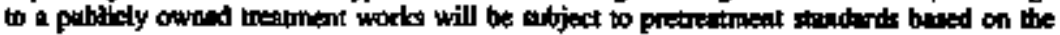
production pocess that generated the prasterater for those procestes entegotion by the EPh.

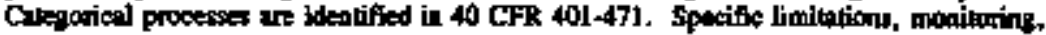

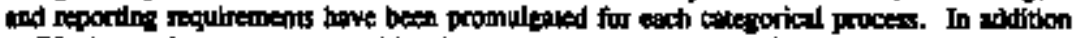

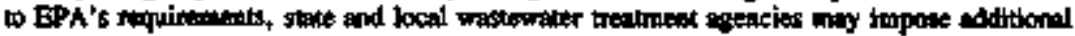

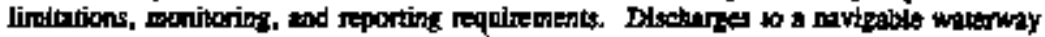

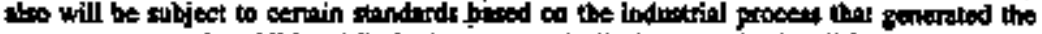

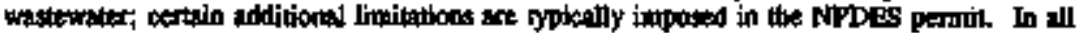

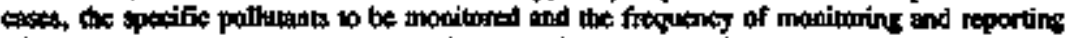

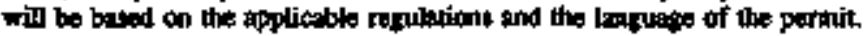


WAC-EP-0497, Rev. 2

This pare intentionally left blank. 


\subsection{IDENTIFCATION ANM CHARACTERTZTTON OF EFFLUENT STREAMS}

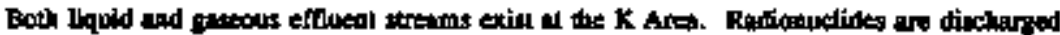

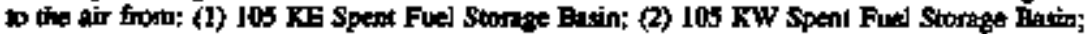

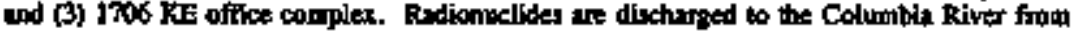
ons discherge point located at the 1908 Outfal, Iso known as NPDES Outfill 004. The

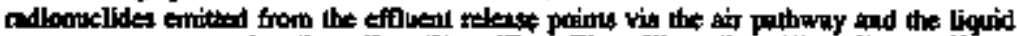

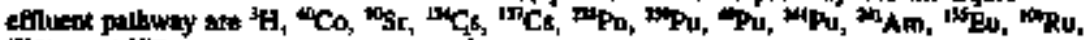
isch, and Liter.

\subsection{IIDNTEICATTON AND CFARACTERTZATION OF CONTAMUNANTS TO EACH BFFLUENT STRKAM}

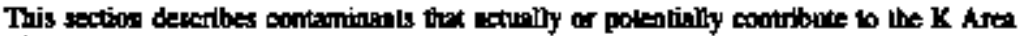

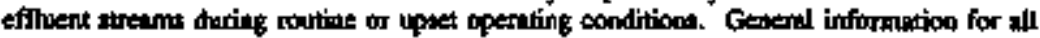

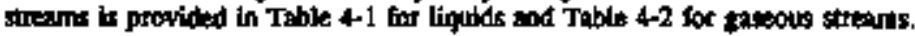

\subsubsection{Rouklne Opentine Conditions}

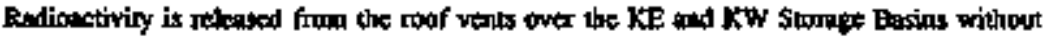
uch of thrironmentil control equipment. The ixotopes that may be released inchude "Co.

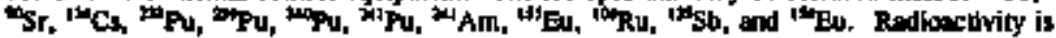
tho released from the roof vents of the 1706 XE office compler. The IXOG XE office

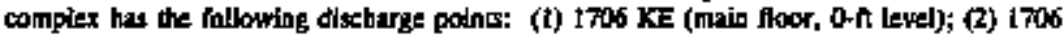

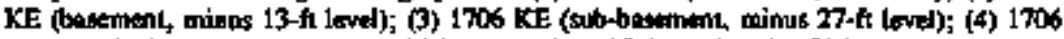

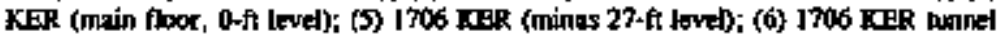
exhoust (minus 27-ft level); and (7) $1706 \mathrm{~K}$ 느 (0-ft level). The izotopes that may be

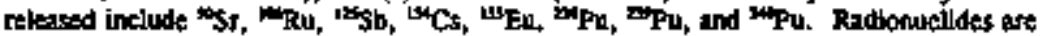

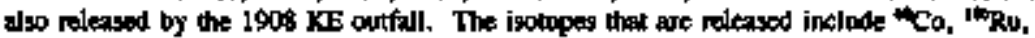

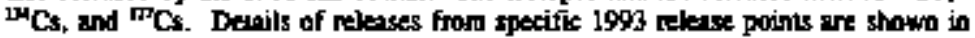
Tabje 4-3.

\subsubsection{Upest Oparmitins Conctoms}

The unplaned-upat polediol effluent was developed by nsing the hightest recorded radionuclide cooceatratons in 105 KESKW Spent Fued Storage Basin water. These highest

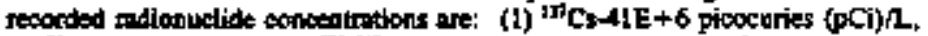

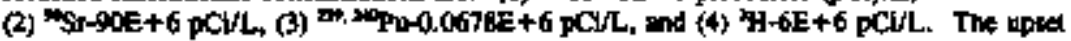

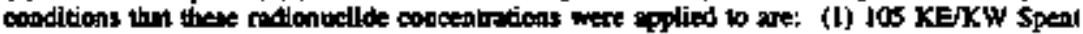

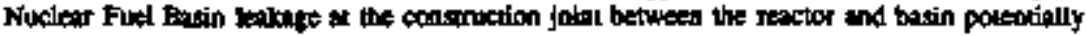


effecting the coil column and groundwale; and (2) a pipo brek in the IOS KF/RW butliding

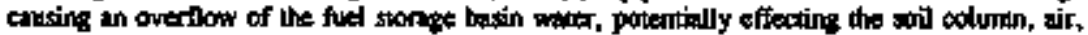

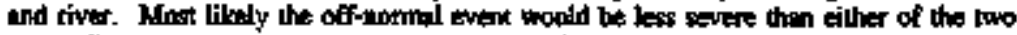

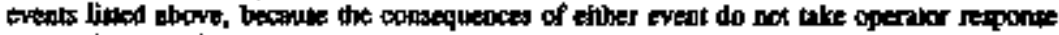
mations ino confideration.

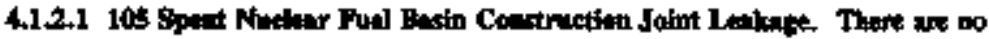

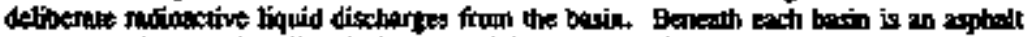
menabrine that was indglled durias the orizingl construction. Tre membane was intended to collext any bagin kalpige and diver it io a tils drintye fleld. The diverion tine bus bee intercepted and coonected to a amp. Any leakere collecked would be pomped from the sump bert into the basin. The betin leak colleston membrane does nith extend to the

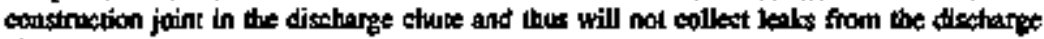
chut:

Basin leaks tht have beep detectod have been atribured to leots in the discbarge chute area. A leak identified in J983 was confirmed to be from the dischage chule. Following the

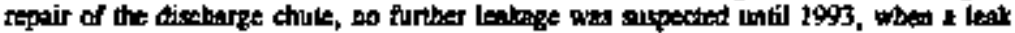

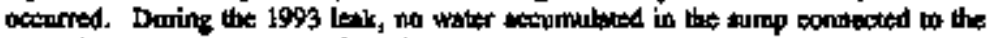
collection membrine. Therefore, it is peculated, altikugh not confirmed, that the 1993 leak, which skopped following in inceses in the bosin wats lemperaturte, was in the Alithar chot chat:

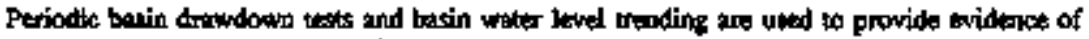
basin leals. Additional checks for lakge are provided by seven groundwater monitoming wells localad around exch basin. Quarkerly empltas from these pells is used to trend and Evare changes in groundwrier quatty us a indkator of a potentili basin leak.

Dut to pest Leats in the basit, in inventory of "

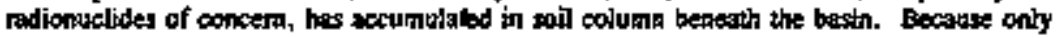
The hiphly mobile trithum (tritiated water) has been detecked in groundwater monitoring wells immediately down-gratilent from the basin, it is astumed that btealdhrough of "Sr, "Cos, and

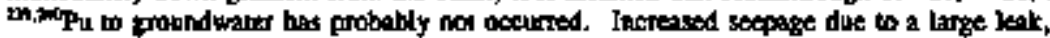
however, may result in trathport of sorne of the soil calumn invediory to groundwater. The

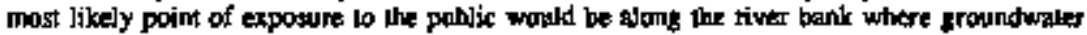
cothiniting tritium and other contamitakbun emerges iv "springs."

To resolve potential eavinosmentpl japacts from basin leakage following an earthquake, isplation bartiers were testalled to seperate the discharge hute from the rest of the basin. These barriers prowide a seismic boundary that would provent loss of waler fron the main basin in the evert an errthquale opens the construction joint in the discharge chute. The

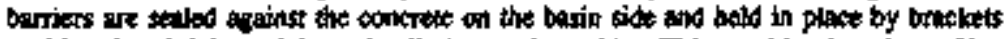
pestifioned and lightened from the dischage chrie side. This would Jeduce loss of bisin

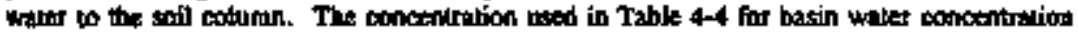

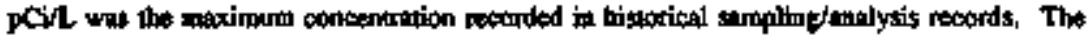




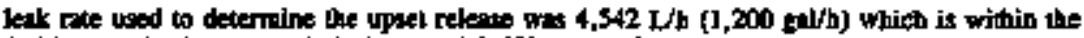

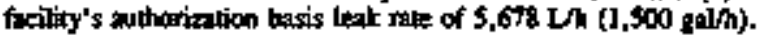

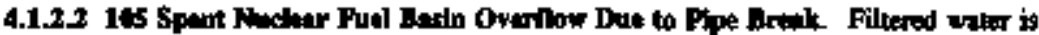

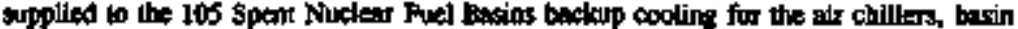

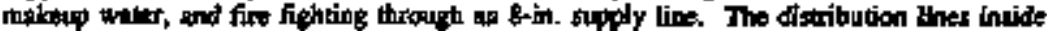

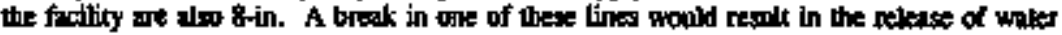

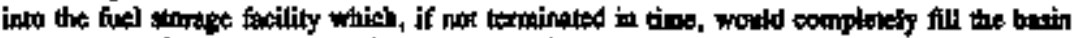
and then overflow through gry floor level openings of the aress smounding the storage Exility.

A comples botal of the 8-in. supply line with a Acrthrough of 3,57/ L/min (2,000 galmin) would fill the basin to ovefilowing in three hours, resulting in a basin ovenflow of approxinately 2,293,950 L $\{606,000 \mathrm{gat})$. Of this quantily, approximately $378,540 \mathrm{~L}$ ( $100,000 \mathrm{gg}$ ) woold flow the river throngh the drains to the outfill, approximately $302,832 \mathrm{~L}(20,000 \mathrm{gal}$ ) pould sask into the soll as a pond formed, and be pood would contain epproximatefly 1,665,576 L (440,000 gal) it its maximum bate. Ths pord's

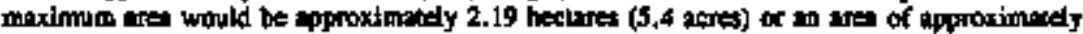

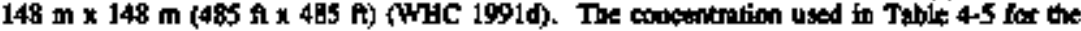
basip water comcentration pCidL was the maxianum enoentrition reconded in historical

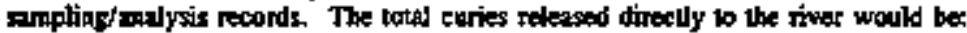
5.J8E+1; retwased to ground, 4.J5E +1; and relessed to the atr by evporition of al] water, $2.27 \mathrm{E}+02$.

Asumptians (HHC 1991d) made for this potential upset condition are:

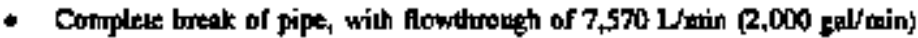

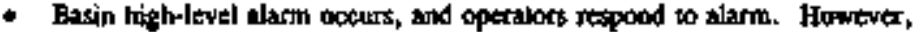
because of conseguences and damage fram the seimmic event, chlorine spill, or

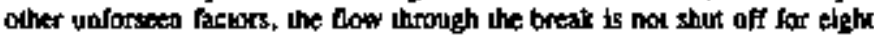
hours.

- All busin overiflow is atsumed to be waler displaced form the basin.

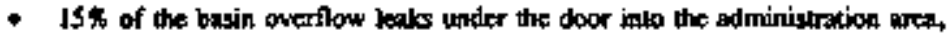
firm where il draing to the basement and inrough drains io the 1908 Oulfall to the stres.

- The remainder of the perfolow drains through the various openings in the palls and under doors to the outside ante esst, north, and west of lie torage facility. forming a shallow pood wilh an averge depth of $8 \mathrm{~cm}$ (3 in.).

- 15\% of the waier that drains to the outside area soals into the sotl as a pond is forminias. 


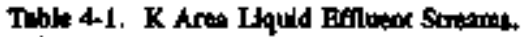

\begin{tabular}{|c|c|c|c|c|c|}
\hline 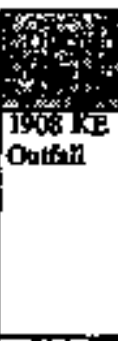 & $\begin{array}{l}\text { a } \\
183 \mathrm{KW} \\
1706 \mathrm{KE}\end{array}$ & 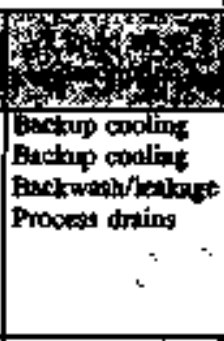 & None & 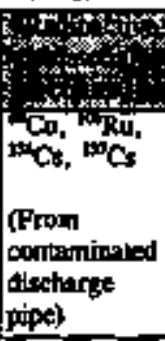 & $\begin{array}{l}\text { andion } \\
\text { oncentration } \\
\text { of } \\
\text { redionuclides } \\
\text { relesed }\end{array}$ \\
\hline Tie fied & $\begin{array}{l}1717 \mathrm{~K} \\
179 \mathrm{x} \\
1722 \mathrm{x} \\
1718 \mathrm{~K} \\
1711 \mathrm{x} \\
1719 \mathrm{~K}\end{array}$ & 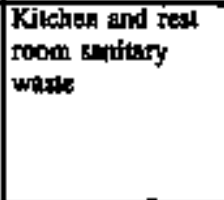 & Nobs: & Fone & $\begin{array}{l}\text { No homentoul } \\
\text { polential }\end{array}$ \\
\hline TIE fET & $\begin{array}{l}\text { J0SKE } \\
1706 \mathrm{KE}\end{array}$ & $\begin{array}{l}\text { Richien and reat } \\
\text { room sambiny } \\
\text { wayere }\end{array}$ & None & Nons & $\begin{array}{l}\text { No friscondout } \\
\text { polential }\end{array}$ \\
\hline Tile field & J05 $\overline{\mathrm{KW}}$ & $\begin{array}{l}\text { Kiteiner and rest } \\
\text { soom saitary } \\
\text { wask }\end{array}$ & None & None & $\begin{array}{l}\text { Notheriodows } \\
\text { potental: }\end{array}$ \\
\hline Tile fred & $163 \times 2$ & $\begin{array}{l}\text { KILERE and jest } \\
\text { room sonithry } \\
\text { waske }\end{array}$ & None & None & $\begin{array}{l}\text { Po handons } \\
\text { potential }\end{array}$ \\
\hline TuE fed & $\begin{array}{l}\text { Tritile by } \\
283 \mathrm{KE}\end{array}$ & $\begin{array}{l}\text { Kicher and iesl } \\
\text { room milery } \\
\text { waste }\end{array}$ & None & None & $\begin{array}{l}\text { No hockirdolis } \\
\text { potentiol }\end{array}$ \\
\hline Jile hadd & $\begin{array}{l}\text { In:IIK } \\
1720 \mathrm{~K}\end{array}$ & $\begin{array}{l}\text { Ritchen and riti } \\
\text { room sanitary } \\
\text { waste }\end{array}$ & N西西 & None & $\begin{array}{l}\text { No hisarardous } \\
\text { potential }\end{array}$ \\
\hline
\end{tabular}


Table 4-2. X Ara Caseous Emuent Surams.

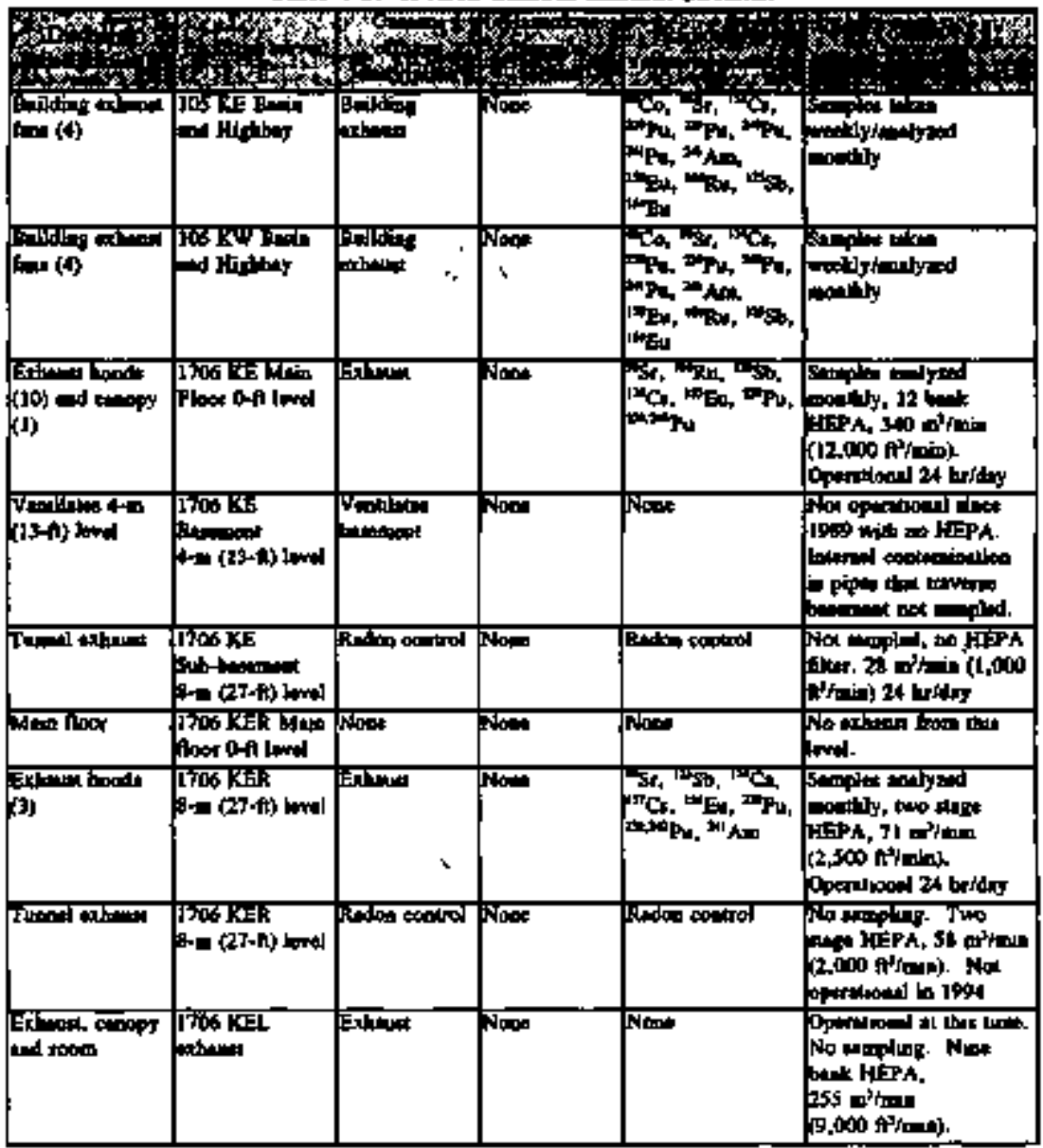

Nots:

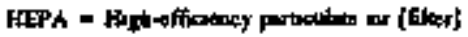


Table 4-3. Normal Operation Rethective Endsebuns for 1993 from $\mathrm{X}$ Area.

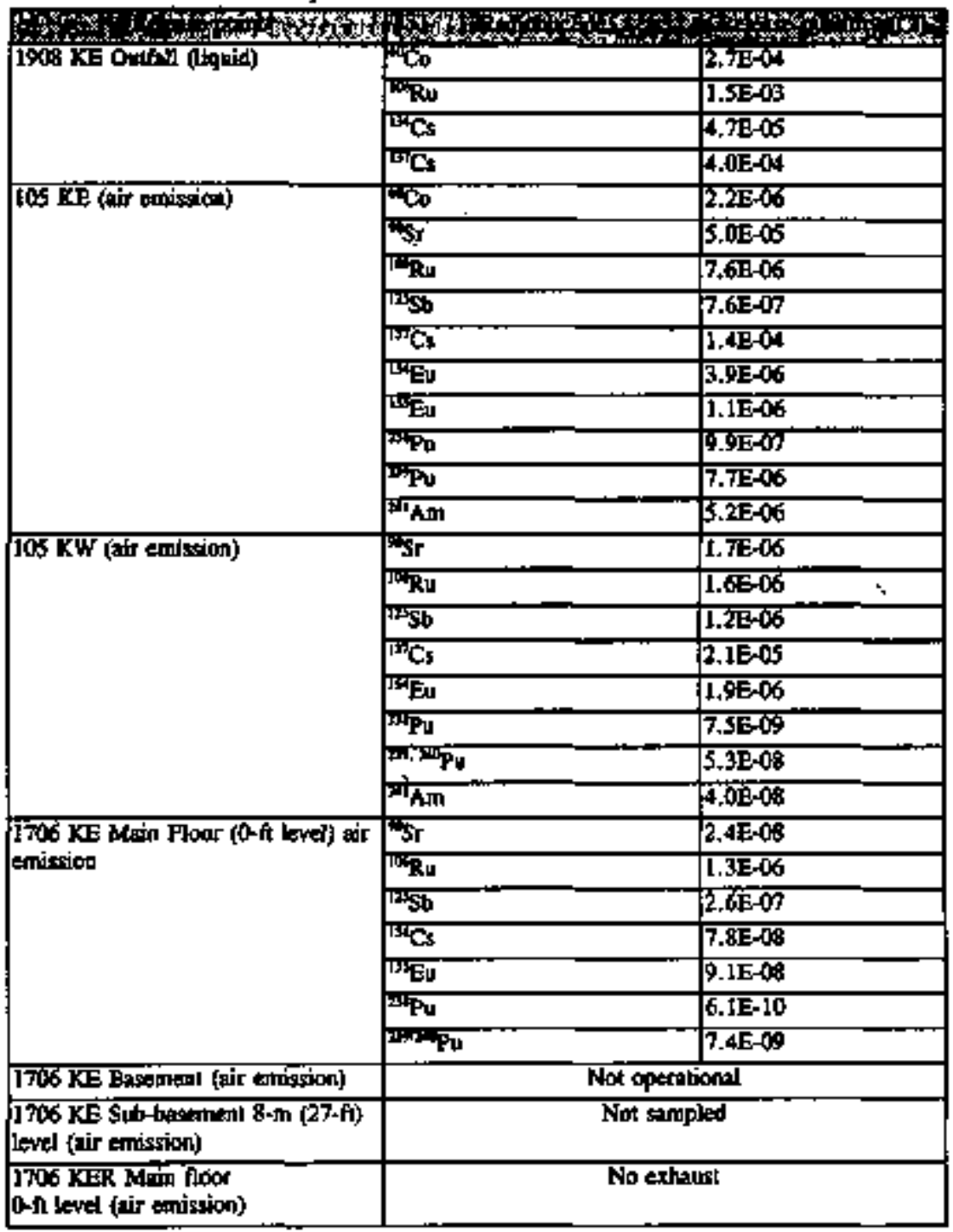




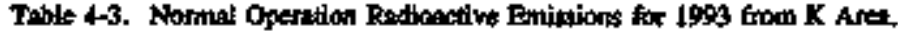

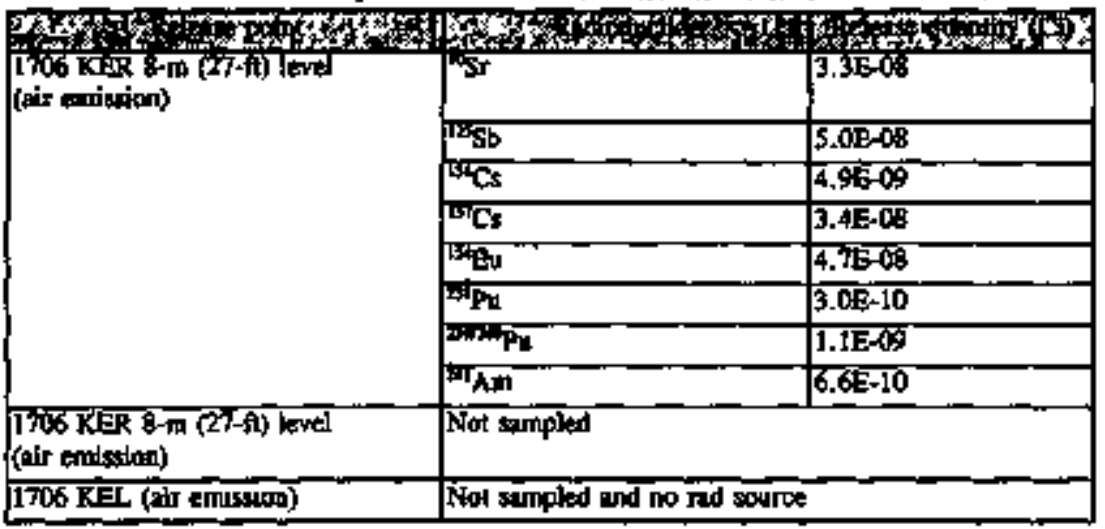

Table 44. Upset Operating Condidons kx 105 Spent Nucleor Fuel Bagin Construction

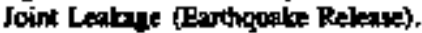

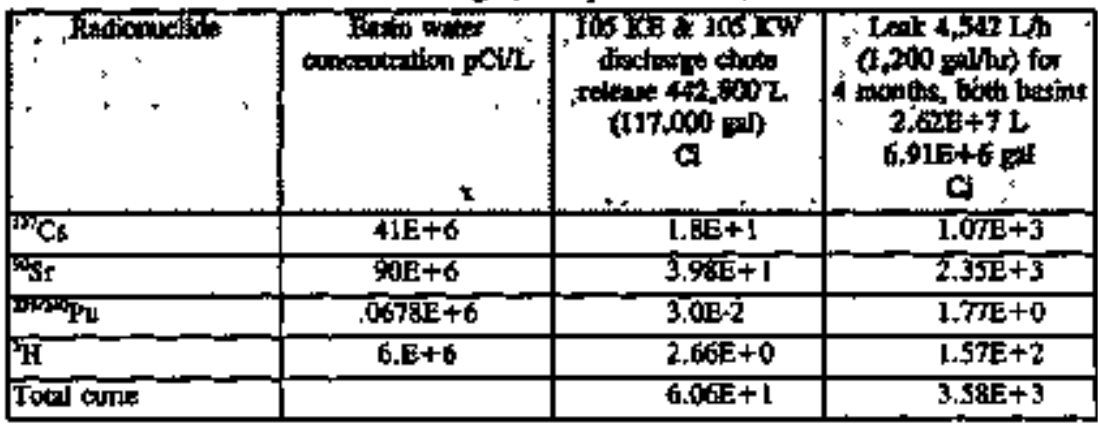

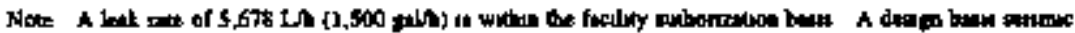

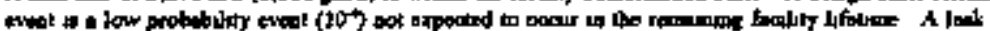

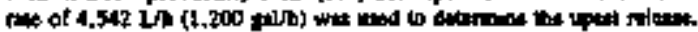

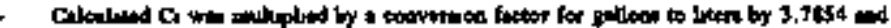
for PO D G b 1.0E-12 
Toblo 4-5. Upset Operaing Conditions for Jos Speat Nuclear Fued Basip Overflom Doe to Pipe Break.

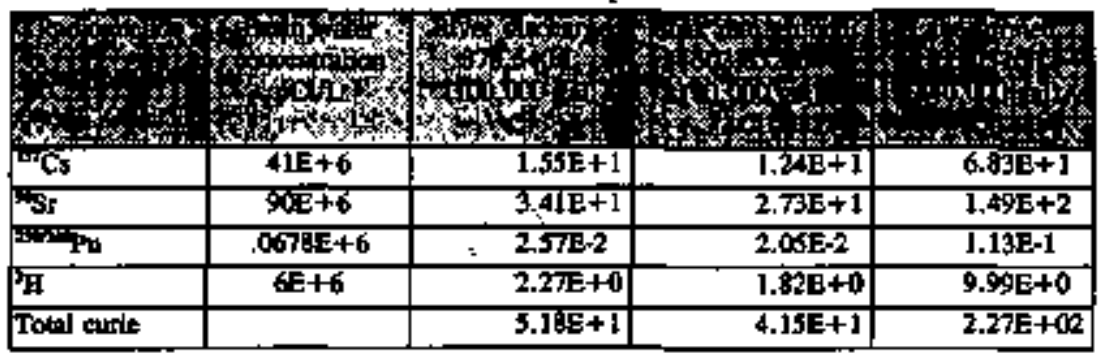

Nom:

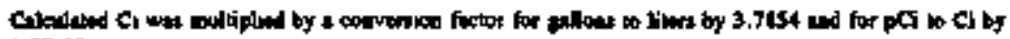
1.06-12 


\subsection{EFTLUENT PONT OF DISCAARGE DESCRITTON}

Of the 16 effivenl discharge points in the $160 \mathrm{~K}$ Arte, only 8 eflucol tischarte points have

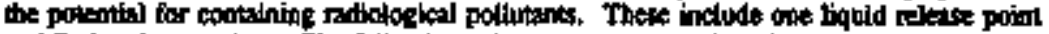
and 7 aff telense points. The following releage point descriptions inclode the precise location

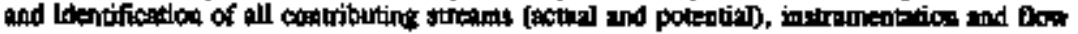
mios.

\subsection{ADREORNR DSCHARGE POINT's}

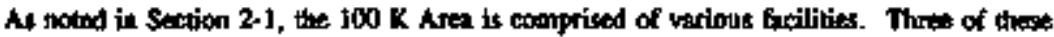

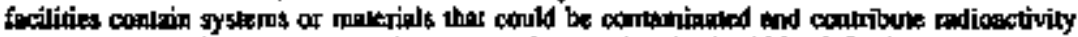

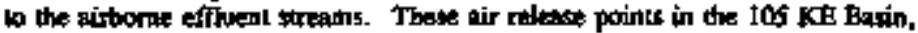

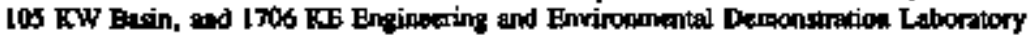
Fatrility complex contist of exhaust vents and are described below.

\section{S.1.1 105 KW Baln Exhnugr Veats}

The $105 \mathrm{KE}$ and $105 \mathrm{KW}$ Basth strucures are to moce respects identical is design and weal

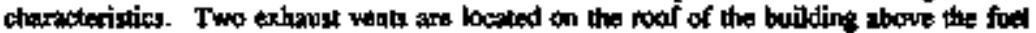
storige basin, and two vents are kooved abowe the transfer are. The vents in the basin and

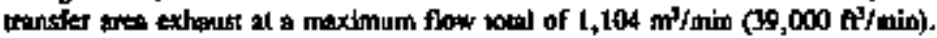

The exhousts vent air directly ob the almosphere withoot treatment (bigh-efficieacy particulate itr (HEPA) fiter).

The rampling systerd ponsigts af three samplers ingide the IDS KW Fued Busin. Of the three somplers, one is loceted in the high bay yres and two are kceted in the krw bay area. All

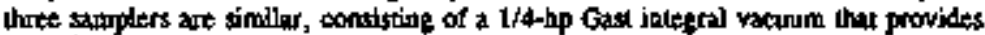
$0.3 \mathrm{~m} / \mathrm{min}$ (1 $\mathrm{ft} / \mathrm{min}$ ) $\mathrm{at} 2 \mathrm{mimimum}$ of $33 \mathrm{can}$ (13 in.). The collection grobes for the

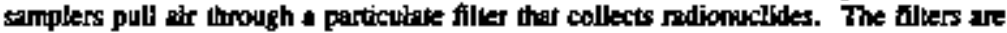

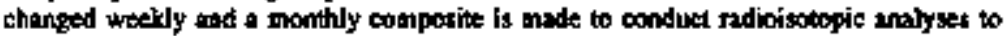

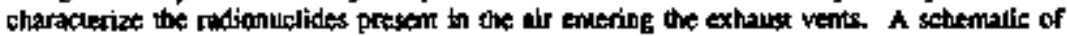
the samplins system is thapen in Figure 5-J.

\subsubsection{KE Basin Fxheuse Vents (Closed by Deenmber 1995)}

The 105 KE Basin exhaust vents are located on the for of of the bajidint directly above the fuel storage batiol and tratsfer ates, approximalely $4.5 \mathrm{~m}$ (15 fi) and $11.5 \mathrm{~m}$ (38 f)

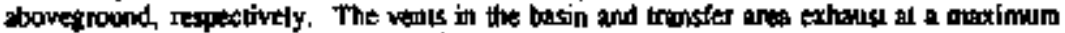
Dow total of 1,529 $\mathrm{m}^{2} / \mathrm{min}$ (S4,000 ft/min). 
WHC-EP-0497, Rev, 2

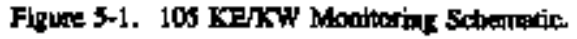

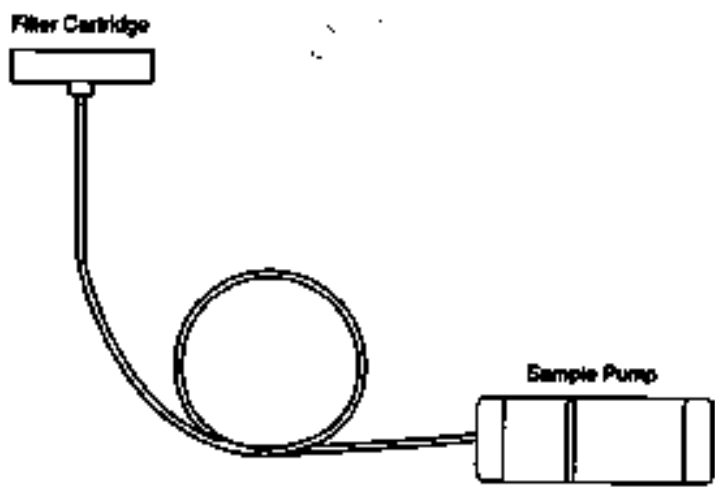

2054504? 


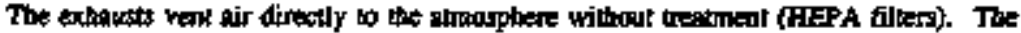

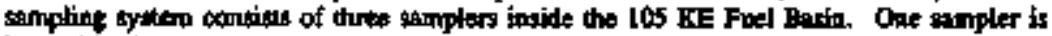
localed in the high bay ore and two yo localed in the low bay sea. Eoch smpler includes

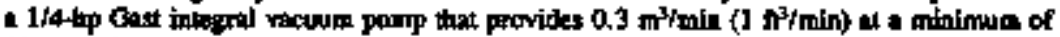
$33 \mathrm{~cm}$ (13 in.). The collection pobes for the samplers ane positioned below the thragst

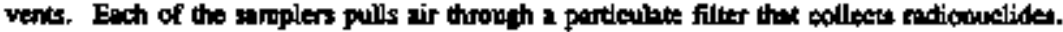

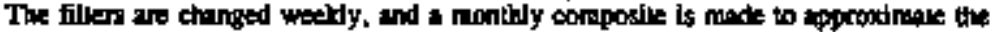

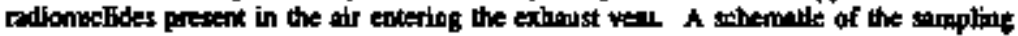
sysiom to shown in Figure $5-1$.

\subsubsection{KE Ofice Complex Exhwur Verts}

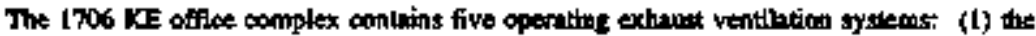
1706 KE exhrost; (2) the I706 KE Tunnel exhruss; (3) the 1706 KFR exhaurs; (4) 1706 KER Turnel exhapst (oot operational); and (5) the $1706 \mathrm{KEL}$, exhoust.

5.1.3.1 The 1706 KE Ehhanst System is localed on the what and roof of the 1706. Baildint-

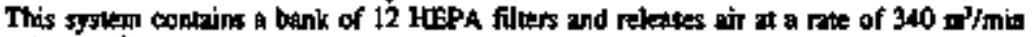
(12,000 $\left.\mathrm{ft}^{\prime} / \mathrm{mia}\right)$. The relesse point is locoled approximately $7.6 \mathrm{~m}$ (25 ft) abovetround.

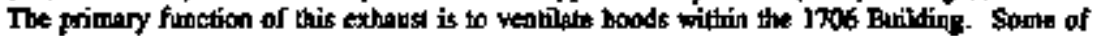
Whe hoods contrin out adjitional stape of HEPA filuation. The HEPA fillers are dioctyl phlhalave (DOP) tested yearly and the hood jlows are checled monlhity. The exhout als is

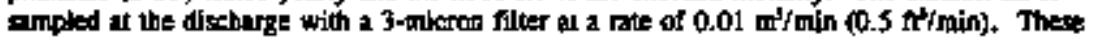

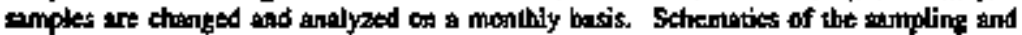
exhausi syonems aft showin in Fieurtes 5-2 and 5-3.

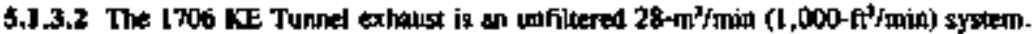
This system is socatced enst of the 1706 KE Buildins at ground level. The discharge point is

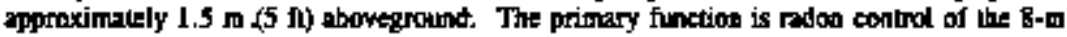
(27-f) lewel in the 1706 KE Eurilding.

5.1,3.3 The 1706 KFR exhaust system is located touth of the 1706 KER Building at ground level. This syater contains a bink of two HEPA filcers and releses air al a rake of $57 \mathrm{~m}^{3} / \mathrm{min}\left(2,300 \mathrm{ft}^{7} / \mathrm{min}\right)$. The releose point is keated approximately $3.7 \mathrm{~m}$ ( $\left.12 \mathrm{ft}\right)$ aboveground. The primary furction of this syskem is to wililate hoods localed in the \&-m (27-fi) level of the J706 KER Building. The HEPA filters are DOP tealed yearly and the bood flows ane checlued monthly. The exhaust aif is sompled at the discharge with a 3 -micron filter al a rate of $0.01 \mathrm{~m}^{3 / a r i n ~(0.5} \mathrm{ft} /$ min). Thise samples are changed and analyzed on a monthly basis. Schentics of the ampling and exhanst systems are showg in Figures 5-4 and 5-5.

5.1.3.4 The 1706 KER Tunnd exhaust is filtered exbaust whth a mor-biage HEPA. The air reterses of tate of $-56.6 \mathrm{~m}^{3} / \mathrm{min}(2,000 \mathrm{ft} / \mathrm{min})$. The primary function is for radon control of the 8-th (27-fy keved th the 1706 KER. Not openational at this trat. 


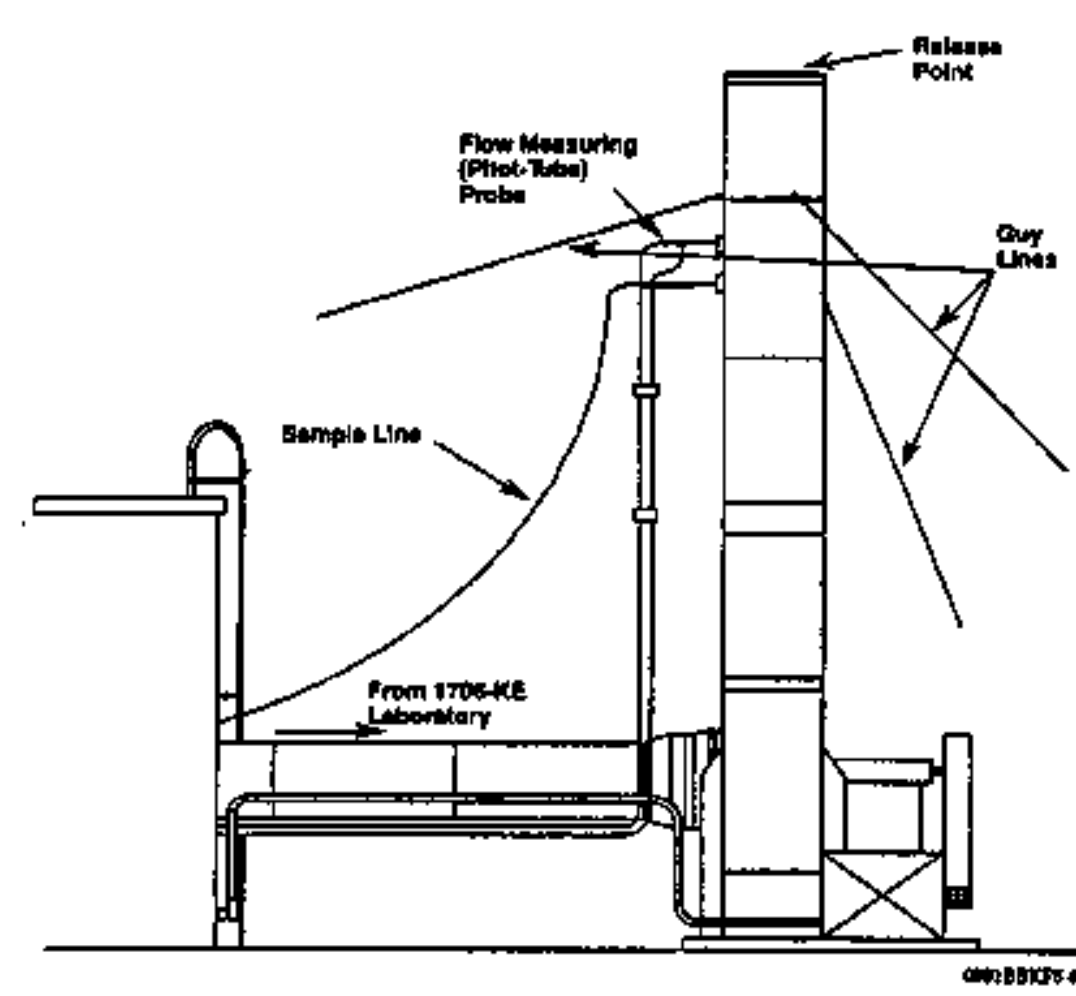




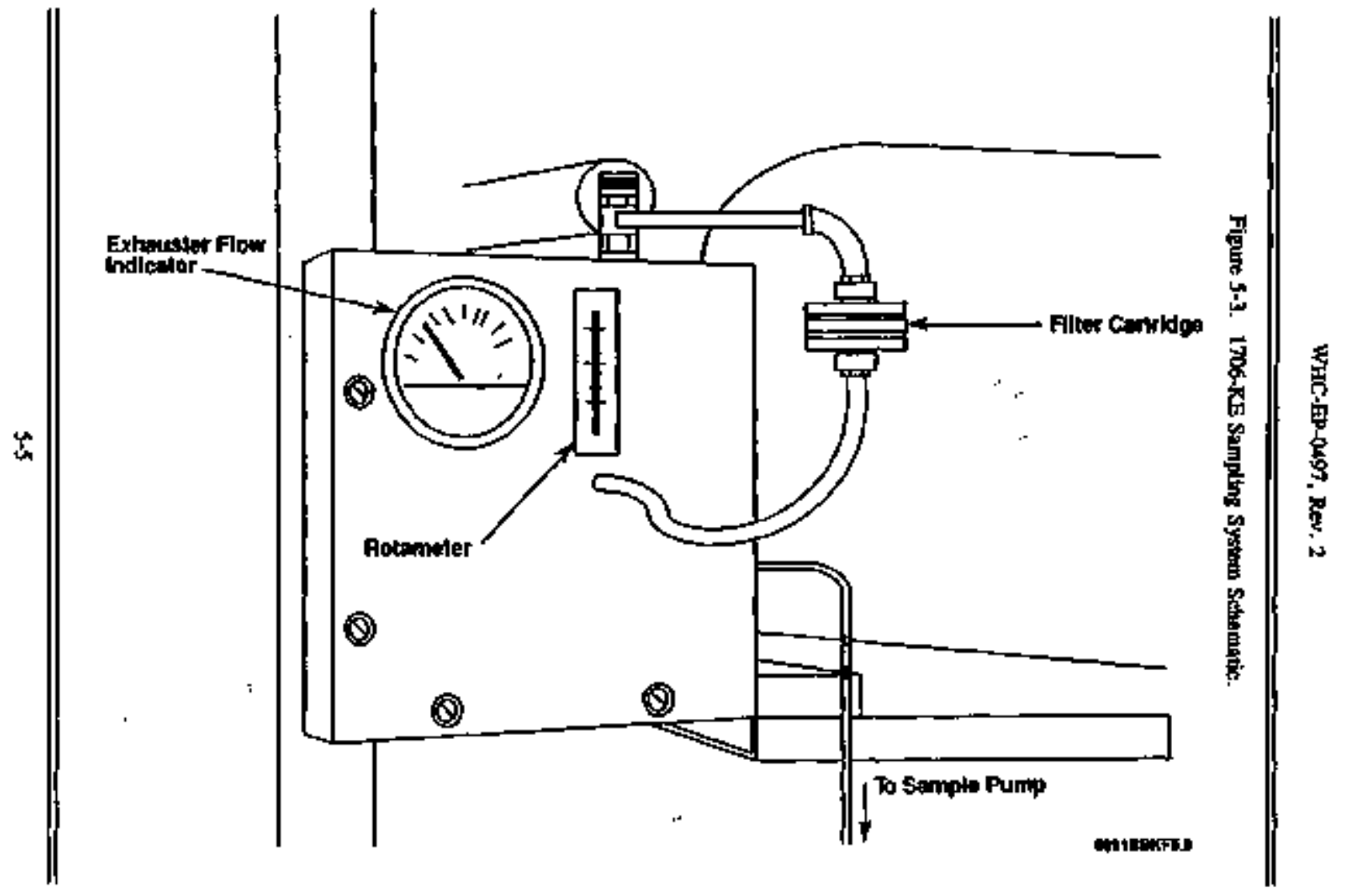




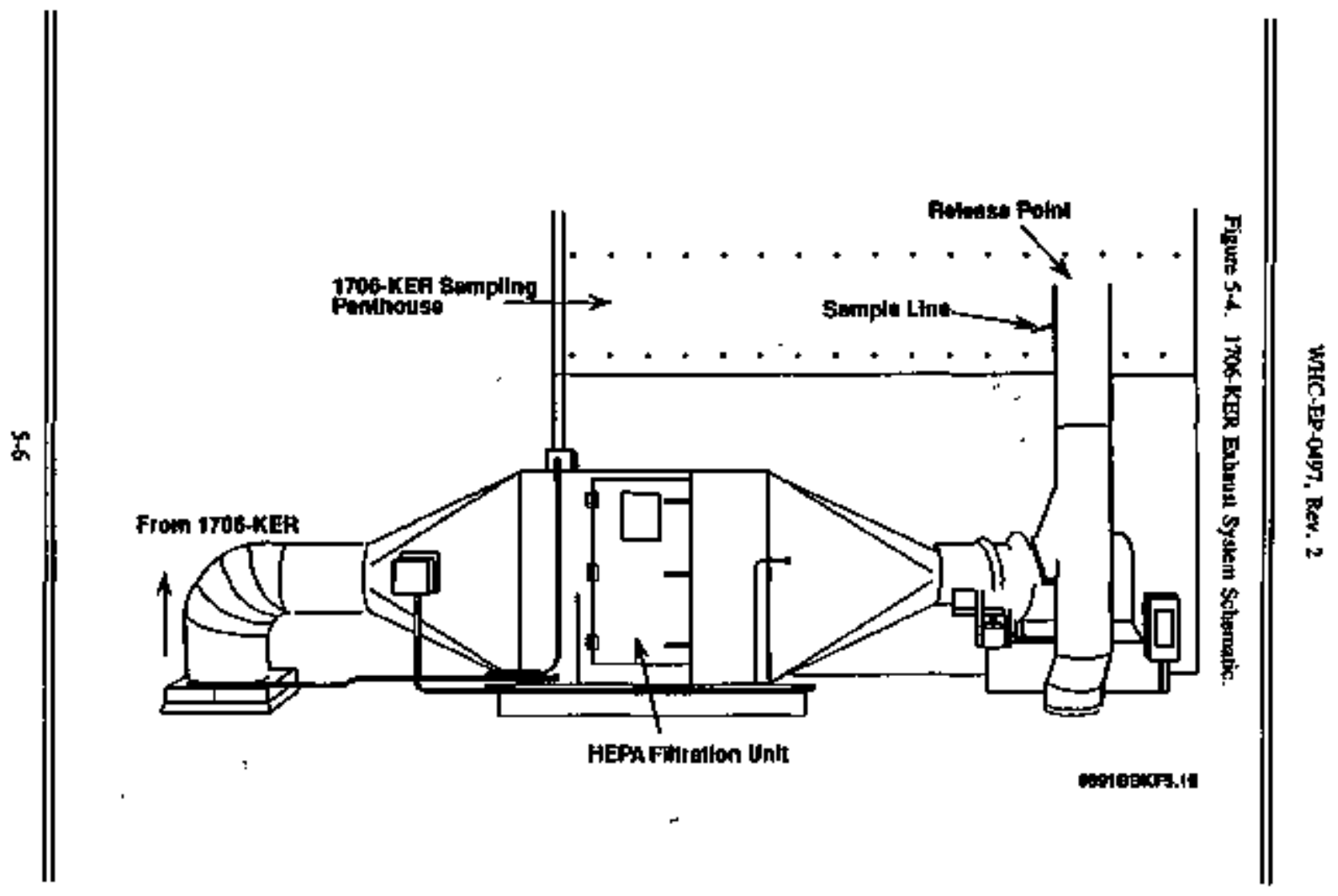


WHC-EP-OA97, Rov. 2

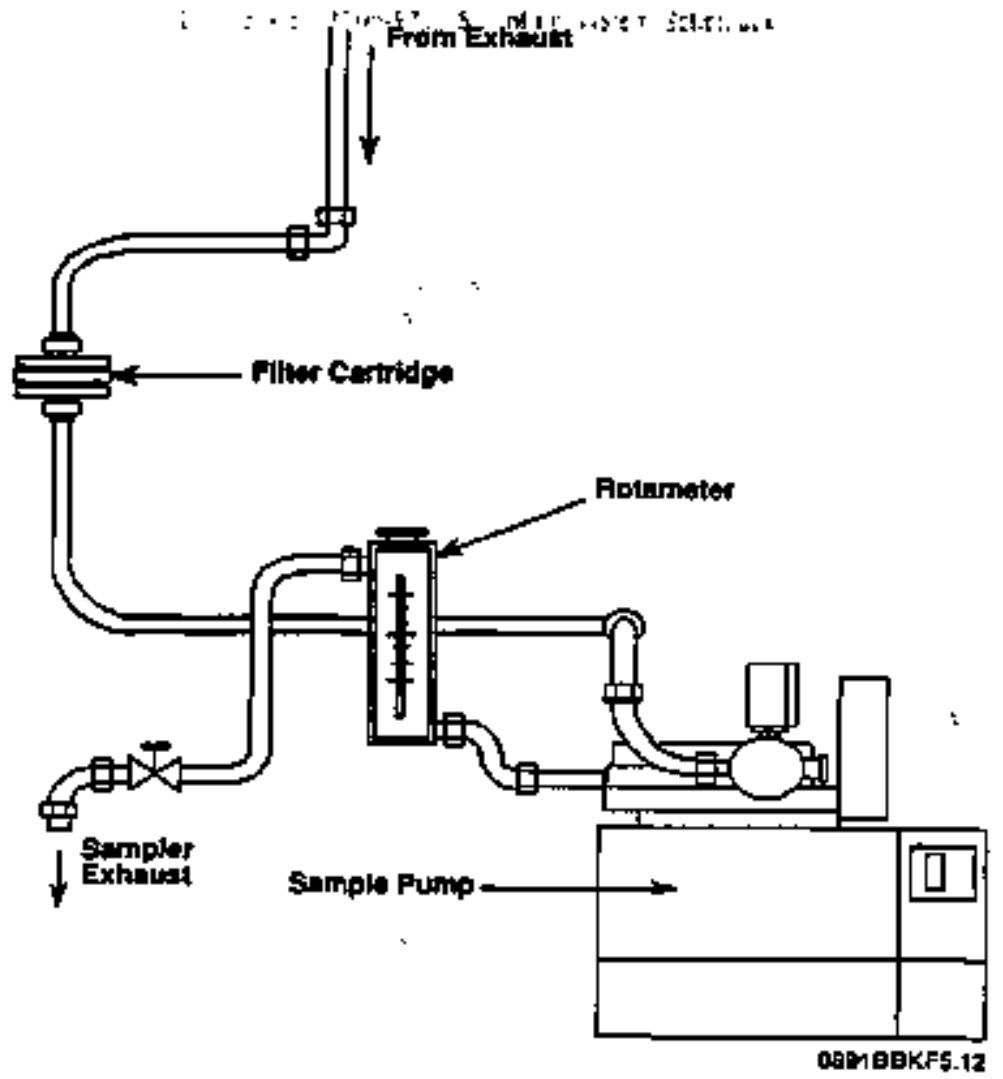




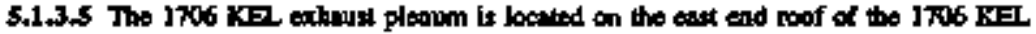

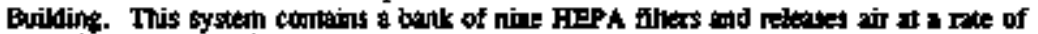

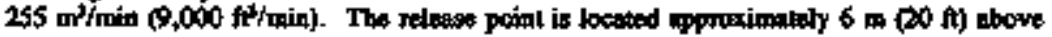

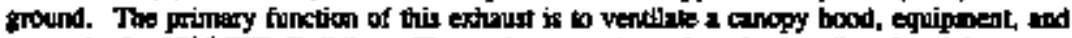

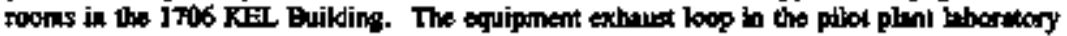
contins one additional troge of HEPA filtritton. The FEPA filters are DOP tested yorty

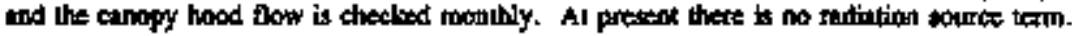

\subsection{LUUID DHCHARGE POINTS ."}

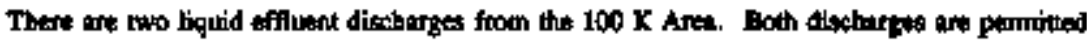
NPDES dischyges. They are permited urier NPDES Perrit No. WA-000374-3 ns Outills 003 and 004 (EPA 1981). A more detrilled deseription of the nelease points is included in the fintowito sections.

\section{2.] 1t1-KE Outha (NPDES Outall 003)}

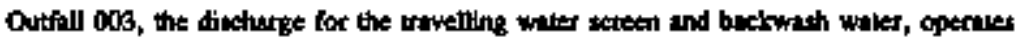

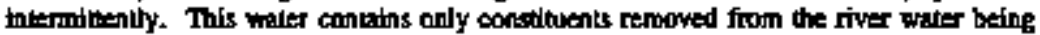

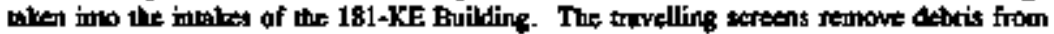

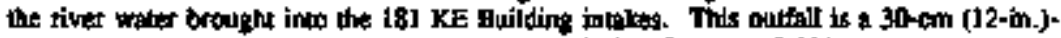
diapeter pipe thal discharges at an averge rive of $18,927 \mathrm{~L}$ day $(5,000$ galday) when operitional. This pipe cones $1 \mathrm{~mm}$ the I81 KE Pumphouse, enkers the fround, and bends wo The nunh befute thistharging beneath the surface of the Columbia Rlver approximately 175 in

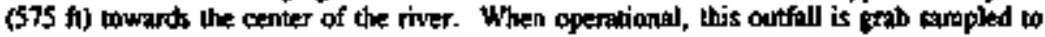
enture NPDES permit compliarce. At present, thit backwesh is colleced and trueked o one of the $183 \mathrm{KW}$ sextimanation basins for eraporation, and thete is no ditshargt.

\section{2 .2 190. KE Outfu (NIOES Onifn' 064)}

The primany linurid effluent tischarte point al the $\mathrm{K}$ Anta is the $1908 \mathrm{KE}$ Outfall. This discharge is permitted as NPDES Outfill 004. The 004 Oulfall is uscd to discharge filter backwosh effluent following seilling of suspended colids in ane of the deactivaled basins. The 0.4 Oudidl alsa fischarges periodic relesses of raw ware from the 183 KE hatid being usad for fish rearing aclivitief, standby cooling wale for the 1OS KE and LOS KW spent fned

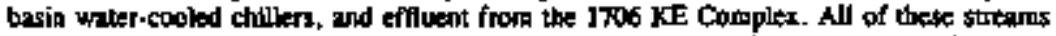
are aon-cadioactive. When the reactor was operational, this onlfill wry nsed to digharge

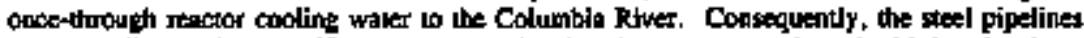

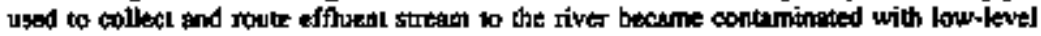
ridionuclides. 
This ouxtall is a pair of 213-en (84-in.)-dtametios pipes that extend $412 \mathrm{~m}(1,390 \mathrm{ft}$ from the

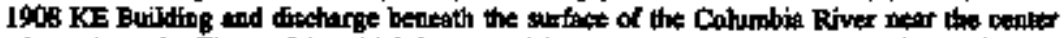

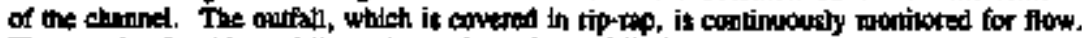

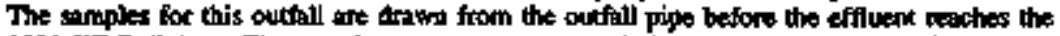
1900 KE Bulitioge. The moles are grab sampled, This outfoll dischurges liquids to the

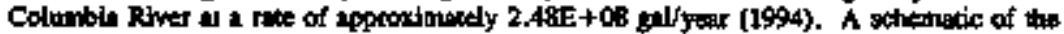

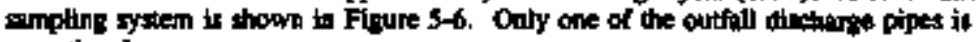
operdions. 
WHC-EP-0A97, REW. 2

Figrore 5-6. 1908-XE Mopiloring Sclematic.

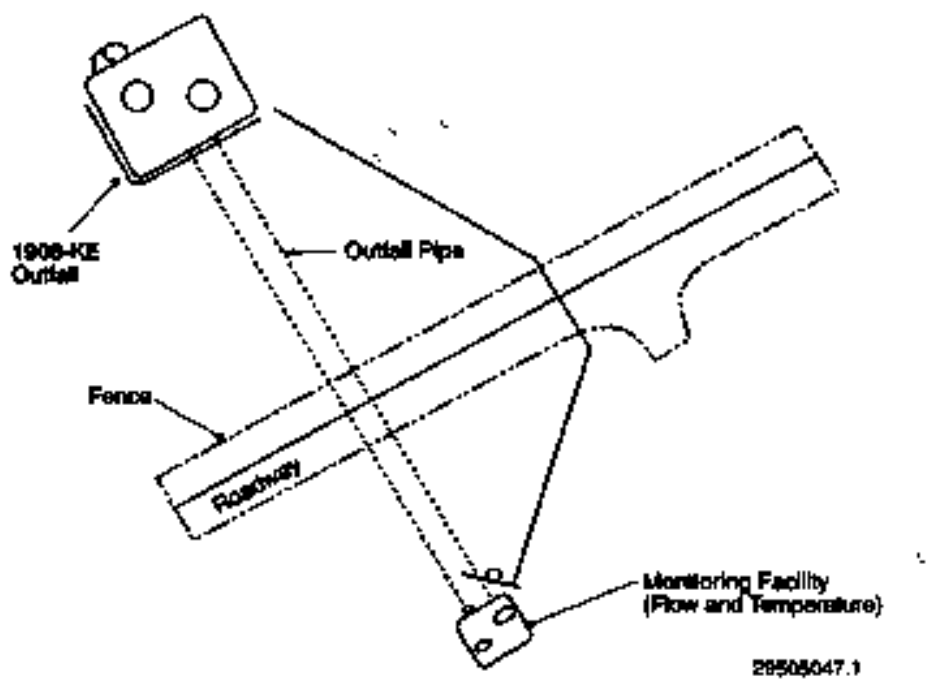




\section{6." EFTLUNT MONTTORINGSAMTLING SYSTEM DESIGN CRMIRIA}

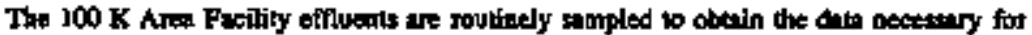

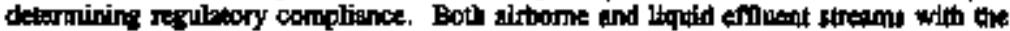
potential fos containing contarinants are mompled for radloactivity, pollubants, and other mazindoar muicrial.

\section{AIREORNE EMISSION SANTLING SHSTEM DESIGN}

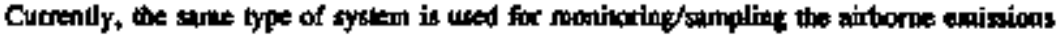

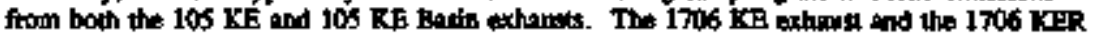

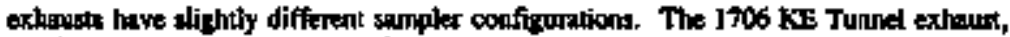
1706 KEI exhaur plume, and l'Fo6 KER Tannel exhaust are nok empled.

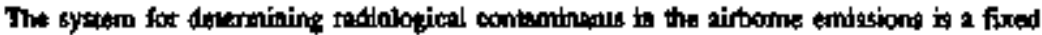

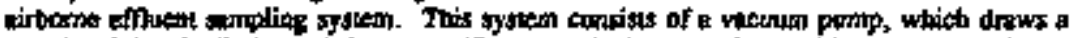

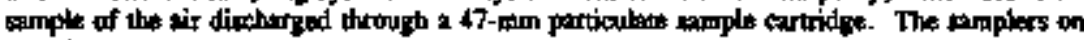

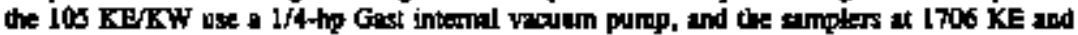

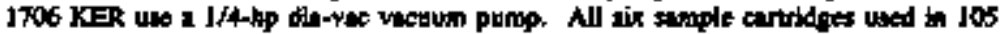

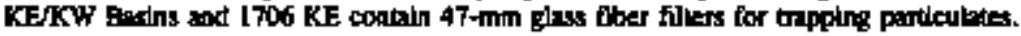

The J706 KER and I706 KE sampling syskens incorporale notimeters to provide direct readout of ampler air flow. In addition, the $1706 \mathrm{KE}$ exhauy syytem has instrumentbion indicating exhauss flow data.

The particulak amples are collected and analyzed from the sample locations ar follows.

- LS KE Basim exhaust: collecked weekly, andyzed monthiy

- 105 KW Basin exhasst: collexied weelyy, analyzed moothly

- 1706 KE exhanst: collected monthly, antyzed anmally

- 1706 KER exhaust: collecied anonthly, chalyzad aminully.

\subsection{LQUID EFFLUENT SAMPIING SYSTEM DESIGN}

Two liquid effluent antpling tystems that ge noed ot the $100 \mathrm{~K}$ Area art foe obtaining discharge data during operation. NPDES Ouffall 003 it an intersmitient disctharbe from the $181 \mathrm{KE}$ inute spucture travelling wates screen backwosh (thol cperational at this time). Grab samples are then during discharge. The 1908 KE Outfall, or NPDES Outfall 004, is ompled by a grob sample collocted monthly. The santpling systom, on Oulfall 004 cosasists of a V-natch watir structure for measuriag flow on a continuous basis. Temperature is measurgd wexty by a grab somple but is read osl continuoutly to the monioring facility. 


\subsection{ON MORMAL RENASES (UASET CONMTIONS}

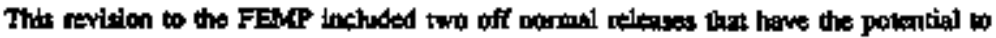
durise the environment. These of acrmal events tre:

1. Pipe breal in the $105 \mathrm{KE}$ or KW buliding, conging an merfluw of the fue

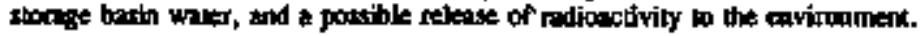

2. Fued suatat busin in ICS KE w $\mathbf{K W}$ wonld leak at the construction joint that cannects the basin wilh the Eictor building.

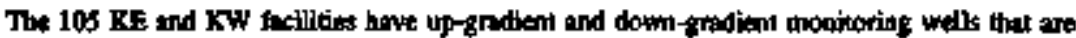

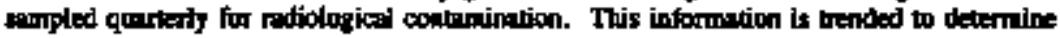
any effects thi $\mathrm{K}$ Basia operotions have on the post-contemination plumes. Also, moatity

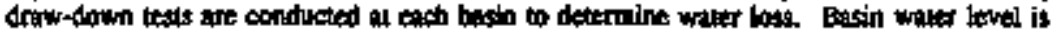
monilored to dotermine whether a leak or ovafill of the basin is occurring. 


\subsection{CHARACTERIZATTON OF CURRFNT EFTLOEKT MONTTORNNG SYSTEM}

\subsection{INSTRUMIENT DKSCRTMON}

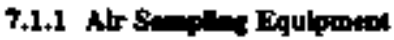

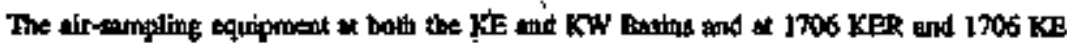
thelluties the forlowing:

- Sumple tube kads from the sample cartidje to the sample pormp.

- A sampte flles eartidge, connizing a 47-nm glass fiber tilter, used to colled particulate.

- A rommetes installed on the [706 KE and JTO6 KEE for measuring: (1) Now nate through the sampling syctem at I706 KE and 1706 KER; and (2) wentilation flow.

- A vaculum pomp for puling alr through the amping syorim.

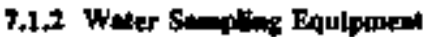

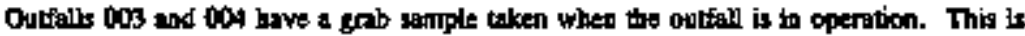
reytired by NPDES pertimil complianes determination.

\subsection{INETRUMLNT STECIFCATTONS}

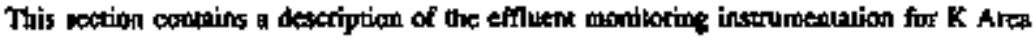
release points.

\subsubsection{Atr Surpitag/Menitering Equipment}

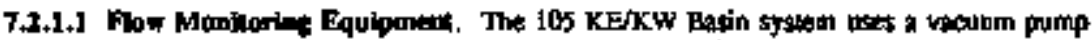
wilh a predeversined flow, which is equal bo the amoout of air that has passed throogh the filur. The flow for exch exhaust is measured annually. With this dace and the atr analysis. the amount of radionuclide rekesses can be calculated.

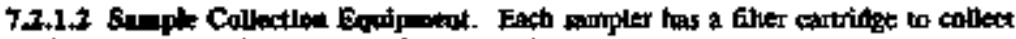
particulate radionuctides relased from the extenost. 


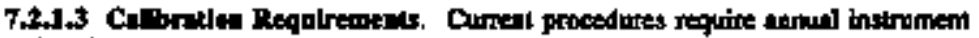
cafidution. Intrumentution calibration is perforsed in accondence whth Westinghouse

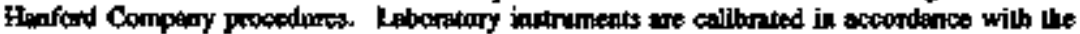
leborstory requirentents.

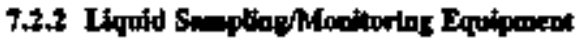

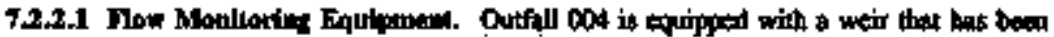

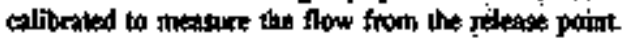

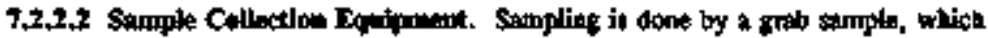
provides a roperestotive sample from the oulfill.

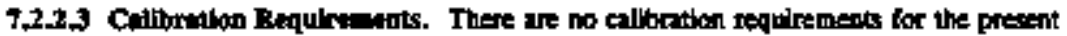

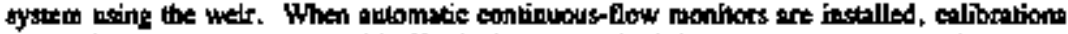

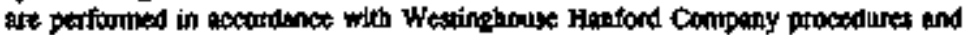

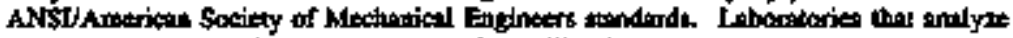
samples will have dielt own instrimemation cealibratton procedures.

\subsection{ALTERNATE MONITORING AND ASSESSMBNT MIETHOOS}

\subsubsection{Alternace Alr Monkoring and Aussment Method}

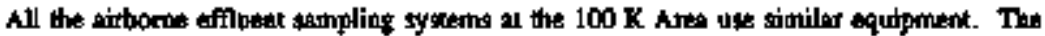
systems consin of a particulate fillog, sample lines, and a racuums punp. In the event of a vacuum pump fallors, the preferred corrective ection is to replace the failed pump with either

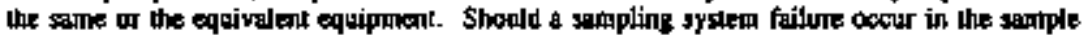

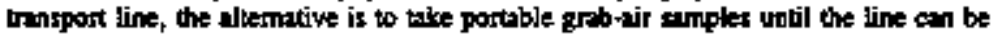
replaced. If emab samples cannol be taken, the fans will be turned off unt the rampling is ontibe.

\subsubsection{Alterime Liquid Embent Momitoring and Aseogneat Mellods}

The liguid efilueat sempling system consigs of a grab sample for Outfalls 004 and 003 . Filow of thuid efiluent discbarte is monitored by a flow weir. The grab ample of the efhuent discharge stream is taken prior to discharge. The grab gamples are random 3.8-L

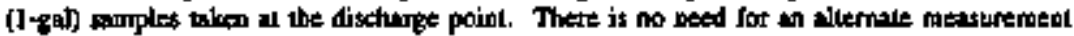
system an the present time. Whato an altowaled samplint system is installed, the presenl system will be temoved. 


\section{8,0 EISTORICAL MOHaTORINGSAMTLING DATA FOR EFTLIFNT STREAMS}

\section{a.1 NokMal CONDrTtons}

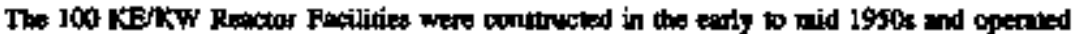

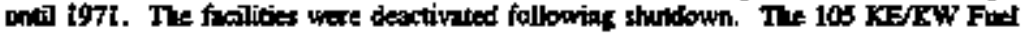
Storage Bagias pere nodified for the interim sorage of N Reactox imdined fuet. Achil

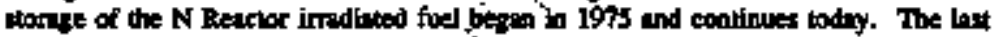

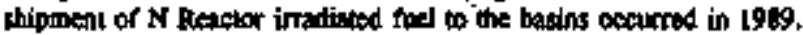

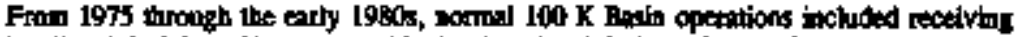

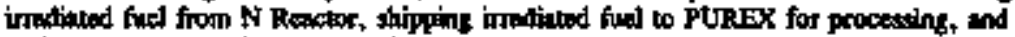
periodically segregating selected fuel elemeals. Modifications to the $100 \mathrm{X}$ Paytits continne

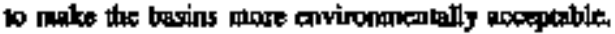

The I706 KE offoe complex) houses the KE, KEL, and KER heillhes. The KE, KEL, and

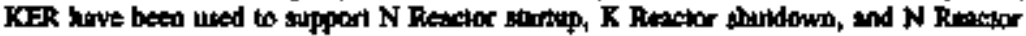
standby. Curterty, the $1706 \mathrm{KE}$ office comples is used by $\mathrm{K}$ Besins to house personoed.

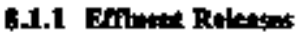

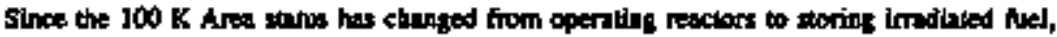
pre-1971 efluent moeiloting results und tectiniques are considered to be non-permine for the $100 \mathrm{~K}$ Area Fue Slorige Balins FEMP. The majority of the worl atter 1975 concerned

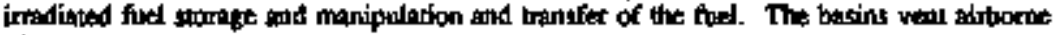
efluent disectly to the atmosphere.

Rodialorical and chemical effluenls from the IOO K Area factitices werc reviewed to determine the potential for rekeasing hazandoes waste. Consequently, it was concheded that orly the radiological effluent releages and NPDES-perpitued effluents merit consideration.

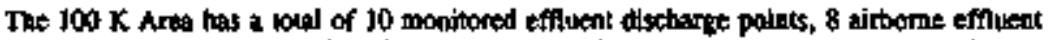
discharge points, and 2 liquid effluent dischroge points. The aitoone disctrarge points wre the LOS KE Basin, 105 KW Basin txhosust vents, and I706 KE Complex. The

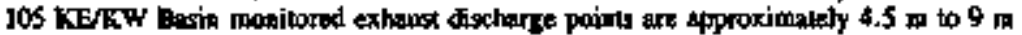
(25 to $30 \mathrm{fl}$ ) aboveground. These release points are uniftered.

The 1706 KE and KER mothitored discharged points ant $7.6 \mathrm{~m}$ and $3 \mathrm{~m}$ (25 ft mid $10 \mathrm{ft}$ ) abowe ground, requeculvely. The KE and KER exhaul through HEPA filters prior to being retexend to the enwironenent. 
The liquid efflute dischare points for the $100 \mathrm{~K}$ Aver are NFDEs-permitted locations

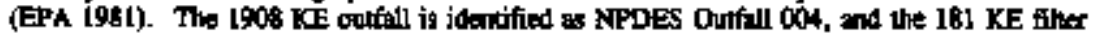
screen backwruh discherge is bentlied as NPDES Oulfall 003. Rationctive atrootne and liguid effluenl discharge tota are included tn Tobles 8-1 through 8-5 tor colendar year (CY) 1993. No rndionctive effluent has been measured ax NPDES Outfall 003 .

\section{U UAET CONDITIONS}

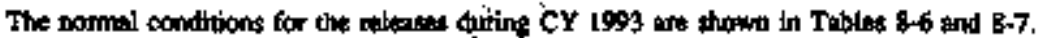

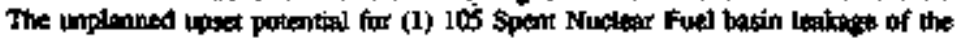

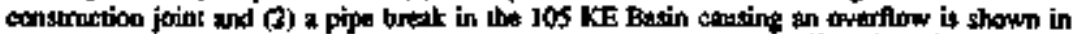

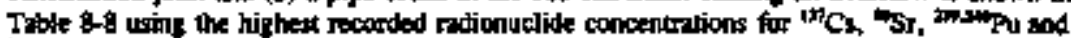
'H in basin witer. Most lltely the off-normal everl would be kess severe than elether of the two everts histed above, becruse the consequences of either event do not ake cpentior response actions into comgideration.

Table 8-1. 105-KE Airtome Efluenu Rekeasen

\begin{tabular}{|c|c|c|c|}
\hline 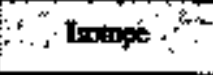 & $\therefore$ ci.(19s3). & $\therefore-1$ potat 1 t & 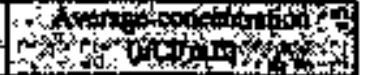 \\
\hline${ }^{4} \mathrm{Co}$ & $2.2 \mathrm{E}-06$ & Exthaost & 3.0E-1S \\
\hline Wr & S.AE-OS & Exhanst & 6.8E-14 \\
\hline Wu & $7.65-06$ & Exhoust & $1.0 \mathrm{E} \cdot 14$ \\
\hline${ }^{12} \mathrm{Sb}$ & $7.6 \mathrm{E}-6$ & Exhaust & $1.0 \mathrm{E}-15$ \\
\hline${ }^{\mathrm{D}} \mathrm{Cs}$ & $1.4 \mathrm{E}-04$ & Exhaust & I.9E-13 \\
\hline Pי & $3.9 \mathrm{E}-06 \mathrm{~V}$ & Exhaust & 5.3E-15 \\
\hline W/E & $1.1 \mathrm{E}-06$ & Exhaust & $1.5 \mathrm{E}-15$ \\
\hline${ }^{2} P y$ & $9.9 \mathrm{E}-07$ & Exhaust & 1.3E-15 \\
\hline${ }^{12} \mathrm{Pu}$ & $7,7 \mathrm{E}-06$ & Exhausts & I.0E:14 \\
\hline MInm & $5.2 \mathrm{E} \cdot 08$ & Exhaust & $7.0 \mathrm{E}-15$ \\
\hline
\end{tabular}

Now:

WHC 1994, 
WHC-EP-0497, Rov. 2

Towle 8-2. $105 \mathrm{KW}$ Aiborne Ethurl Relose.'

\begin{tabular}{|c|c|c|c|}
\hline gs: & $1.7 \mathrm{~B}=06$ & Exhlust & 2.3E-15 \\
\hline Tक्षRU & 1.68406 & Exthost & $2.2 \mathrm{E}-15$ \\
\hline${ }^{2} c_{5}$ & 2.1E-1S & Extrox & 2.9E-14 \\
\hline 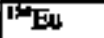 & $1,9 \mathrm{E}-06$ & Exhlyost & 2.6E-I5 \\
\hline$\overline{P u}$ & $7.5 E-49$ & Ex)hot & $1.0 \mathrm{E}-17$ \\
\hline 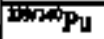 & $5.3 E-08$ & Exbaux & $7.25-17$ \\
\hline$m_{h}$ & $4.0 \mathrm{E}-018$ & Exlbust & $5.4 \mathrm{E}-17$ \\
\hline
\end{tabular}

Now:

nusc toma

Table 8-3. 1706 KE Airbome Effleent Reicases.'

\begin{tabular}{|c|c|c|c|}
\hline$\therefore$ & " tes & 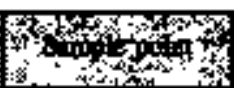 & A \\
\hline Sr & 2.4E-B⿺ & Exknowst & $1.3 \mathrm{E}-16$ \\
\hline$\sqrt{T_{R} \|}$ & 1.3E-06 & Exhwest & $7.3 \mathrm{E}-15$ \\
\hline $\mathrm{in} \mathbf{s b}$ & 2.6E-07 & Exhaust & $2.5 \mathrm{E}-15$ \\
\hline${ }^{14} \mathrm{Cs}$ & $7.8 \mathrm{E}-0 \mathrm{~B}$ & Exhauat & 4.4E-16 \\
\hline स्ञ & $9.1 E-08 \%$ & Exhaurt: & $5.1 \mathrm{~B}^{16}$ \\
\hline${ }^{2} \mathrm{Fu}$ & $6.1 \overline{E-10}$ & Exhaust & $\overline{3.4 E-18}$ \\
\hline $\operatorname{sen} p \bar{x}$ & $7.4 \mathrm{E}-09$ & Exhowst: & $4 . \overline{1 E \cdot 17}$ \\
\hline
\end{tabular}

Noo:

\section{IWAC 1994.}


WHC-EP-0497, Rev. 2

Table 8-4. 1706 KER Aiburio Efiloent Relescy.'

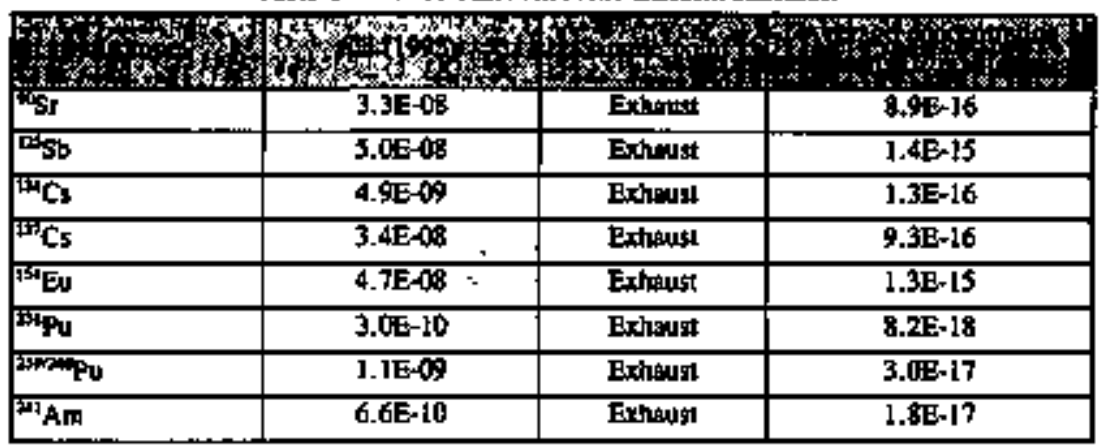

Note:

WHC 199.

Table 8.5. LOR-K Outiall liquind Efthuent.'

\begin{tabular}{|c|c|c|c|}
\hline 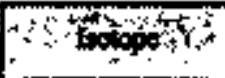 & co (19s) - & 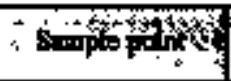 & Sw \\
\hline बि० & 2.4E-04 & o0d & $3.0 \mathrm{E}-10$ \\
\hline की & $1.5 \mathrm{E}-06$ & $\overline{004}$ & 1.7E-09 \\
\hline$\sqrt{\mathrm{CCs}}$ & A.JE-0S & 004 & $5.2 \mathrm{E}-\mathrm{II}$ \\
\hline$\sqrt{14} \mathrm{Cg}$ & A.OE-OA & DOA & $4,4 \mathrm{E}-10$ \\
\hline
\end{tabular}

Nove:

IWHC 1904 
WHC-EP-0497, ReV. 2

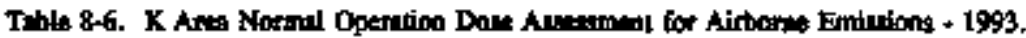

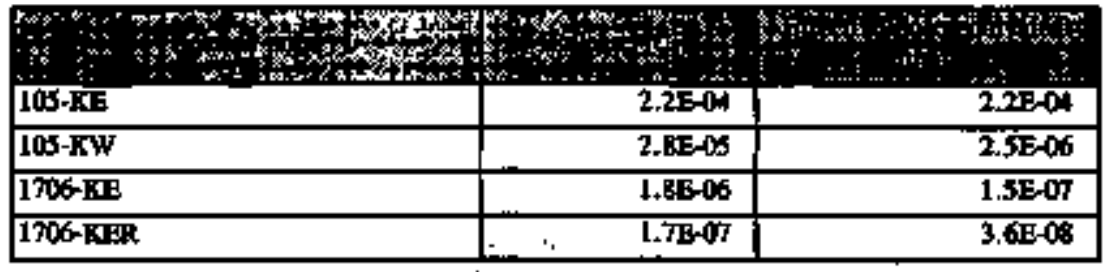

Notes

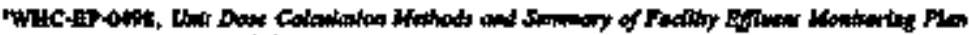

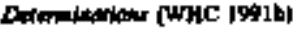

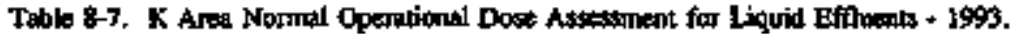

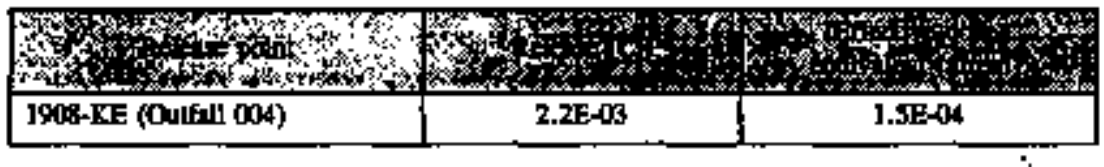

Notr

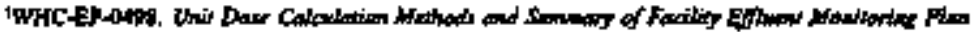

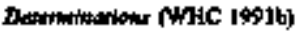

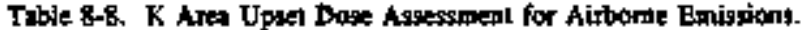

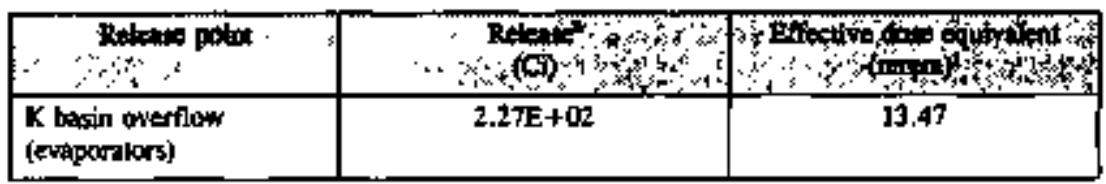

Now

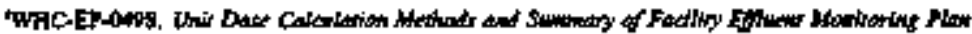
Dotomikdilon (W/AC L991b)

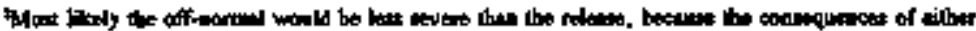

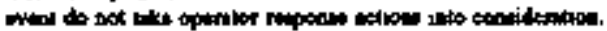


Taley 8-9. X Aro Upat Dose Assessment for Liquid Effluents.

\begin{tabular}{|c|c|c|}
\hline L Basin butrolow ontalt & $5.18 \mathrm{~g}+1$ & $5.2 E+0$ \\
\hline K Enalin overtlow grownd & $4+15 E+1$ & \\
\hline 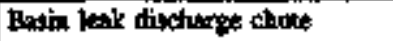 & $6.06 \mathrm{E}+1$ & \\
\hline $\begin{array}{l}\text { Baxin logk 4,542 L/min } \\
(1,200 \text { gal/min) for four months }\end{array}$ & $\therefore \quad 3.58+3$ & \\
\hline
\end{tabular}

Nothe

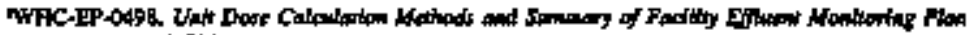
Determinetions (W/K 199/b)

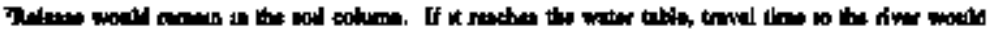

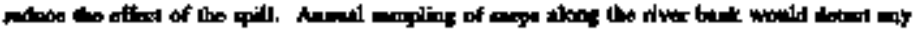
moracent of the lipuid rolowac.

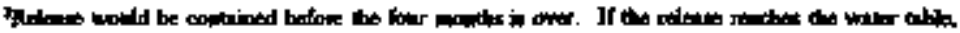

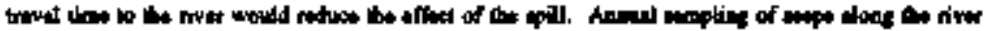

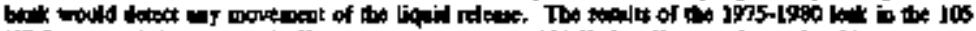

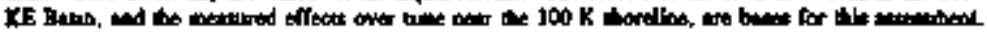

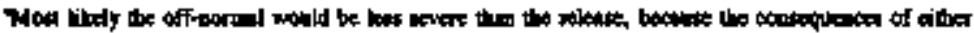

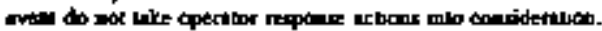




\subsection{SAMTLE ANALYST}

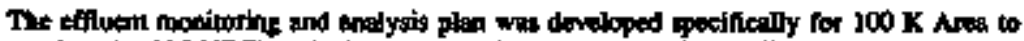

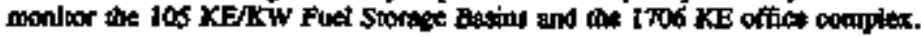

\subsection{PUIRONE}

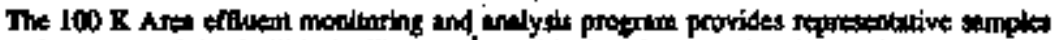

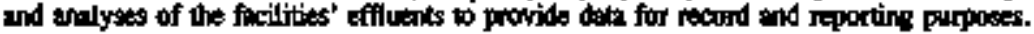

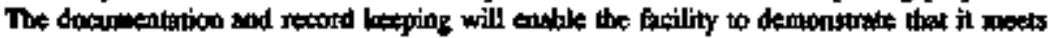

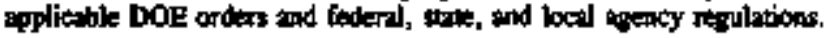

\section{2 mackerouk}

The 100 Area has been operring an efloed montioning proprim tince the $100 \mathrm{~K}$ Reactyr begen operatiod. What the reactors were dectivated, this montioning progran was no

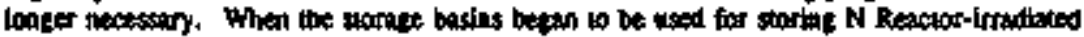
fict, sompling was aprin cothblishad.

\subsection{SAMTUING SCHFDUIE, FREOUENCY, AND STRATIGY}

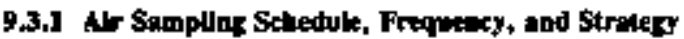

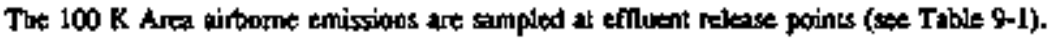
The selection of air monitoring equipmeint, method, and frequency is bosed on ithe calculared

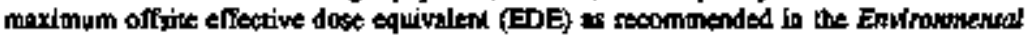
Regulanory Gwide for Sirnew Monitoring and Swretilonce (DOE 1991b) and the estimated dose from the ctual aitome efluents neleased by the fieility in 1992. Selection of the equipment is based on the efflueat nitpulatory goide and past efflunil sanpling performod routinely for thsignificent dots approaching background. Selection of effluent monilosing equipment, anethod, and frecyvarcy is based on the following criteriot

- Effluen ntbotiocing melhodimax amual offrite dost

- Continuows onlinefoffline moruitor: to 20,1 mremsycar

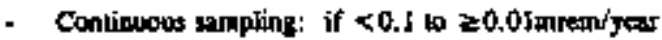

- Periodic confirmatory measureneal: If <0.01 mrem'year. 
Table 9-I, Air Sarpling and Analyteal Reguliements.

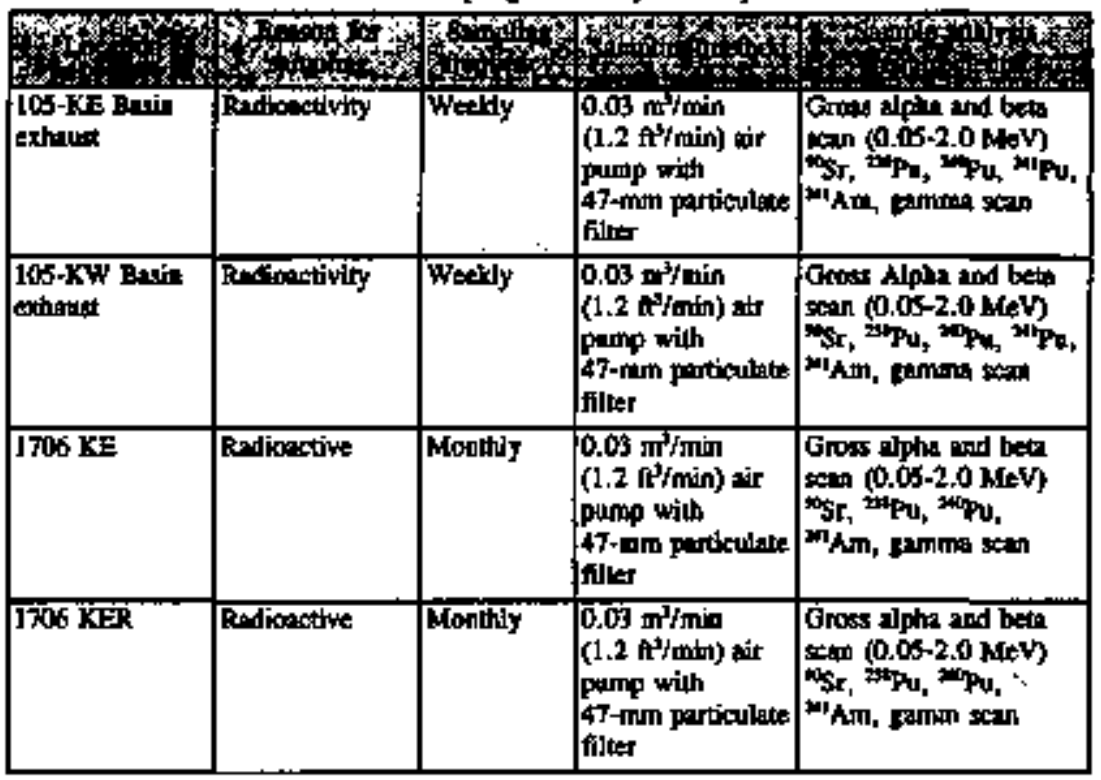

\subsubsection{Water Sompte, Scledule, and Frequency}

Waur sampling is b be performed al the liguid effluent discharges to the Columbin River. The sampling localionts, thow moniloring, sunpting frequency, safolple size, sarngling method, and analytical requirements art givtn is Table 9-2.

\subsubsection{Grwandwater Monltorins}

Groundwoter moaimaing al the 105 KE and KW busias has been conducted under several proerams. These programs include towituring during the period when the resclors were operaing, to the prescat period of hmiled operations ipvolving fuel storage and environtiential restoration activitins. 
The groundwater monitoring wells are located both wp-eradient and down-gradient of the fuel skorage basins (Figure 9-J).

Table 9-2. Liquid ESfluent Sampling and Amalytical Requthoments.

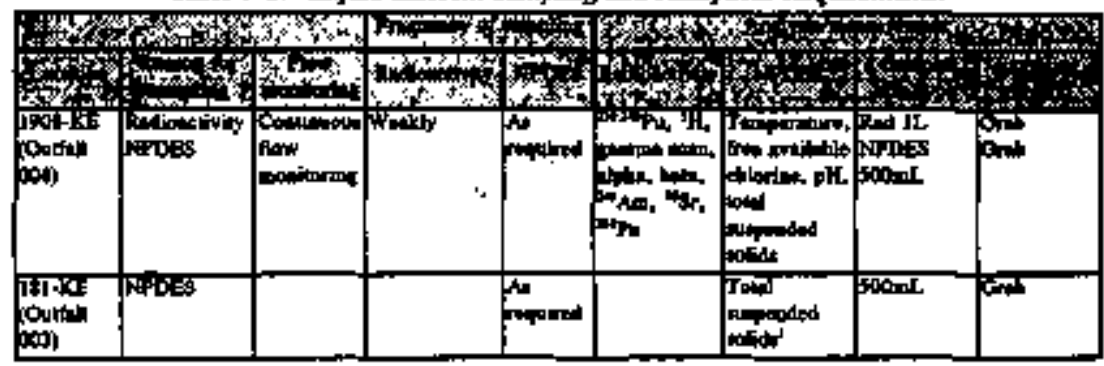

Now:

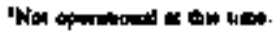

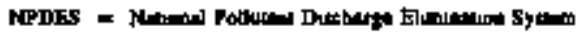

\title{
9.4 SAMULE ANALYSIS, DETECTION, AND ACOURACY
}

\subsubsection{Alr Somples}

Air samples gre collected at four effluent retease poits idolified in Toble 9-1. Nil the tir samples collected ane particulate smples from continuous air sorolples. The air samples are

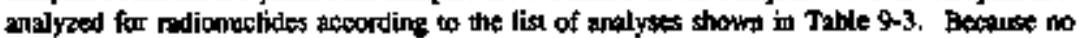

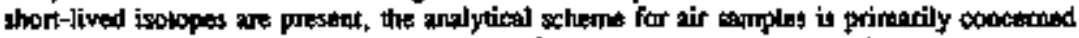
with identifying the long-lived activation and fisson isotopes and deteminiag the concentration of the specific redionuclide being emitted. The analyses listed in Table 9-3 are

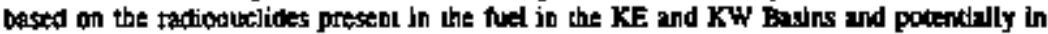
minor amounts in $1706 \mathrm{KE}$ and KER.

The minimum detactable copentrations (MDCs] for the specific radkochernical analywes are shown th Table 9+3. The MDCs for the air simples are very low because of the large sample ize of $800 \mathrm{k} 1,500 \mathrm{~m}^{\prime}$. An MDC of this magnitude will readily devect redionueclides al or near backgtound levels for specific adionuelides.

The zecuracy foe the andlyses is $25 \%$. The 2ocuracy and the ptosision of the various anslytical methoos are verified by a daily check sounte. sumple blanks, and splked samples. 


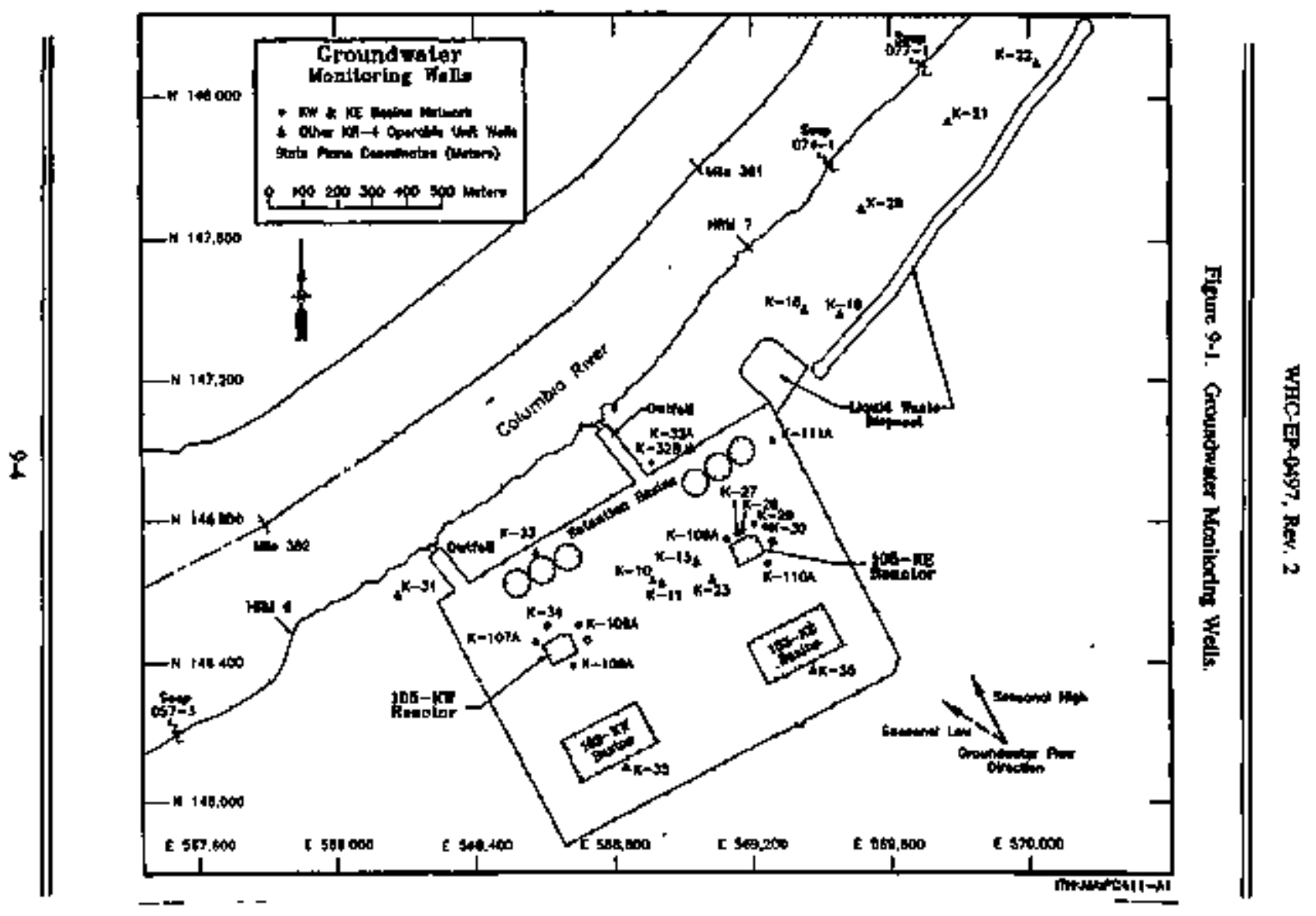


Table 9-3. Rafinchomicol Anolytiogl Methodt and

Limits kt Airtume \$amplos,

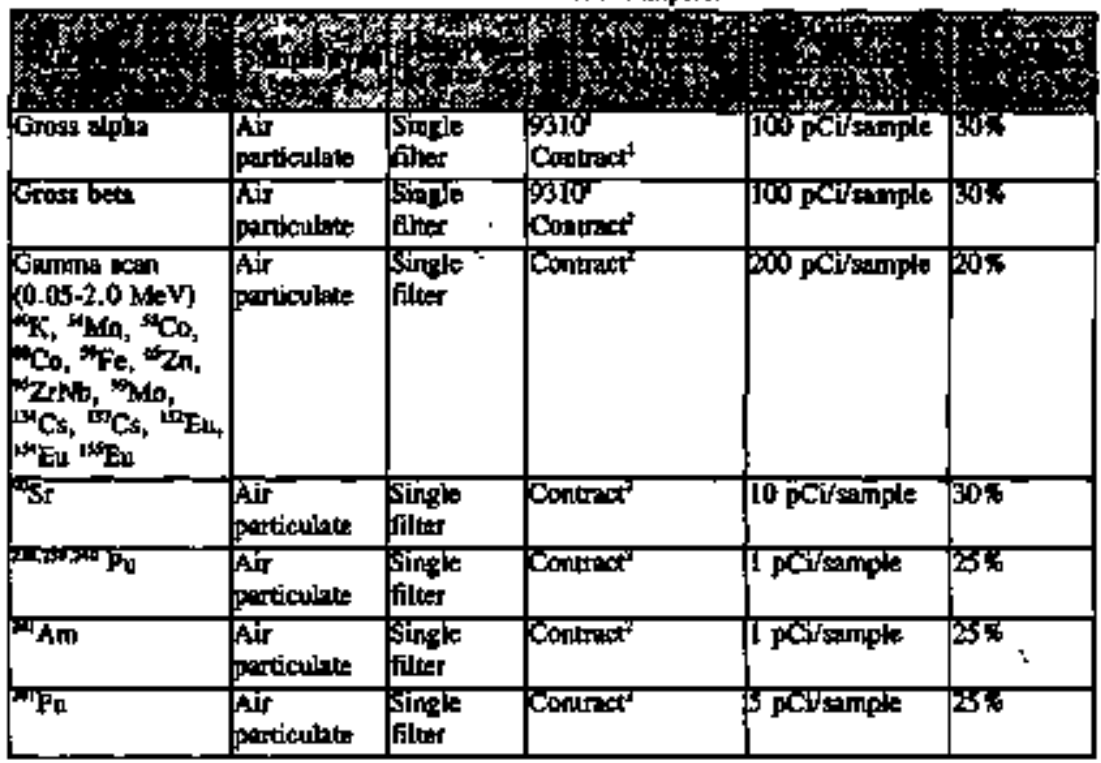

Nonq:

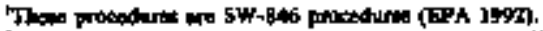

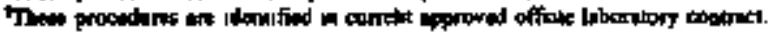




\subsubsection{Wuler Simples}

Watex ranples are takes from the liquid efloent monitoring points thown in Table 9-2 to fulfill the DOE and EPA requirenents for monikoring tor tadiloactivity and spetified

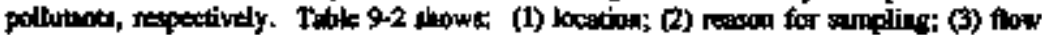

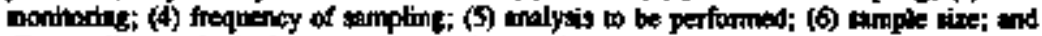
(7) ampling method, The samples art than malyzed for the redionuclides as thown in Table 9-4.

Table 9-4. Radioclemicil Aalytiogl Methods and

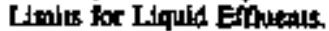

\begin{tabular}{|l|l|l|l|l|}
\hline & & & \\
\hline
\end{tabular}

Nowe:

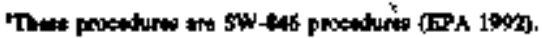

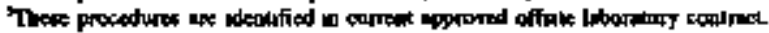

The minimurt detection linums for the fadianucllde fot the litquid effivent samples are given in Table 9-4. The table shows the rablysis of the radionuclide, sample type, sample size, andytical method, MDC, and socuracy of the trethod. The analytion melhods used in this enviranesental monioring plan are from EPA SW-846 (EPA J992), Westinghouse Hanford Company's 222-s Laboratory procedures, or contract laborakry procedures sivhorized by the analytical services. The accoracy of the aratylical methods is tetermined as part of the owerall calibtation procecture, and is checked on a taily besis by using calibration elheck sources, stample blanks, spiked sadiptes, and spltt samples, which are pan of the overall Iaboxtabocy Quality Coatrol (QC) projram. 


\section{9,4.3 Gromidoter Singles}

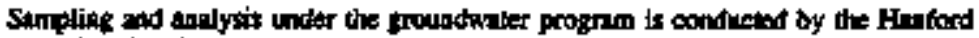

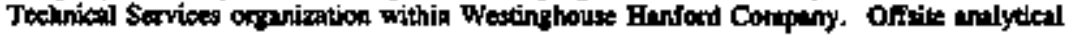

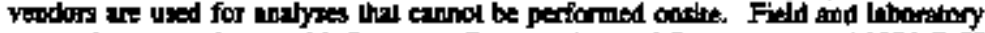

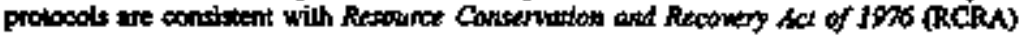

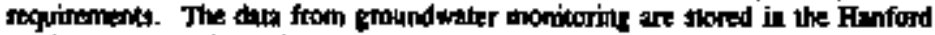

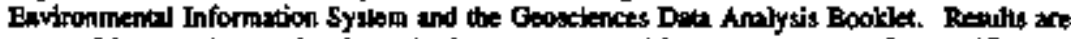
reported in anmal operational monitoring progroms and in ceperate heports for specific

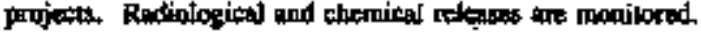

\subsection{SAMPLE SHIPPDNG AND SAMPLE CHADN OF CUSTODY}

\subsubsection{Stmple Shlpoine}

The variows types of efflueta simples from $100 \mathrm{~K}$ Aree are to be pacloged and shipped fron

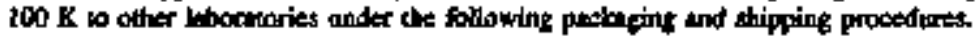

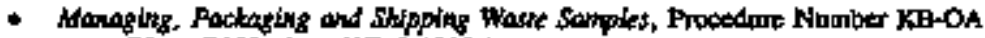
and WH-DI-EOC2 (from WHC 1990).

- OndwH Desk Indructions.

The shove procedures ensure that wastit anpiles are packaged and shipged to eicher Hanford Sile baboratories or oflsite laboritories thal meet the packagtag and shipping repuiremen's of DOE, Nustitit Refulatory Combisission (NRC), Deperthent of Tranipostalion, and Wadrington Stale.

\subsubsection{Surple Custody}

Effluesl samples from the $300 \mathrm{~K}$ Area are trinsported to the laboratory under an admitistrative chain-of ctustudy procedurt.

The purpose of the chain of exstody is to create an accurate written record that cal be uyed w trace the possession and handiting of a wave sample in the process of being chareterized.

\subsection{EFFLUENT MONTTORING PROCEDURES}

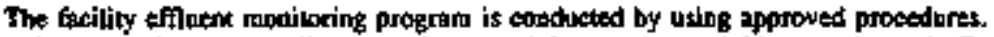

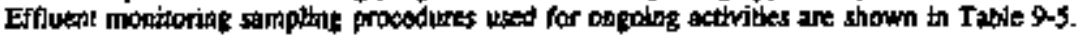


Table 9-5. K Area Effluent Siamping Pocedmot.

\begin{tabular}{|c|c|c|}
\hline 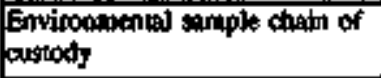 & $\begin{array}{l}\text { Qperations Andysiss and } \\
\text { Weste fancling }\end{array}$ & KB-DARWHDJ-EOO3 \\
\hline 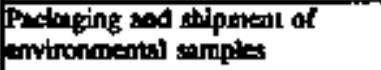 & $\begin{array}{l}\text { Dptrationd Antyrits and } \\
\text { Weste Fandiling }\end{array}$ & KA-OAdWH-DI-0id \\
\hline $\begin{array}{l}\text { Collection of NPDES and liquid } \\
\text { efflucat anples }\end{array}$ & $\begin{array}{l}\text { Dpertions Andyst and } \\
\text { Watte Fanding }\end{array}$ & X Batin 59/60-50-1 \\
\hline Air sumpling & Heallh Plyysics & K.W-001 (WHC 1994g) \\
\hline Quarterly flow checks & Foolth Paysics & $\mathrm{K}-\mathrm{Q}-0 \mathrm{OS}$ (WHC 1994b) \\
\hline Efinent waitoring poctaduts & Effluent Emiqgions Montoring & $\begin{array}{l}\text { WHC-IP-1666 } \\
\text { (WHC 1994) }\end{array}$ \\
\hline $\begin{array}{l}\text { Elluend data vorificalios, } \\
\text { validation, recocthetping, and } \\
\text { dose calcolationd }\end{array}$ & Eflnuebl Emistions Montiparing & $\begin{array}{l}\text { WHC-IP-1066 } \\
\text { WHC I994f) }\end{array}$ \\
\hline 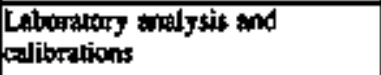 & 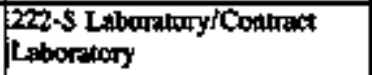 & 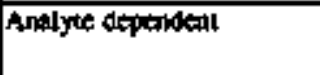 \\
\hline 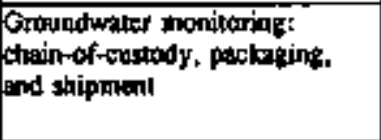 & Hanford Technical Sorvices & $\begin{array}{l}\text { Proceduat uod ar to } \\
\text { supporl Hanford Site wide } \\
\text { groundwater monituris } \\
\text { programs. }\end{array}$ \\
\hline
\end{tabular}

\subsection{U.S. DEPARTMENT OF ENERGY ANALTTICAL AND LABORATORY GUIDELINES}

The andytical and leborany procecturb for the FEMP activities are identified th Seclion 8.0

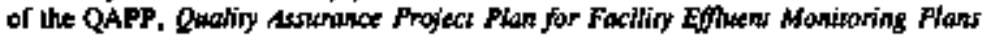
(WHC 1994c). General reguirements for babortory procednres, data analyses, and statistical treatret are addressed in the QAPP. Detailed descriptions of these requirements are given

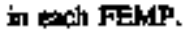

The following elenents tdeolified in Envimnmentel Regulatory Ouide for Radialogicol

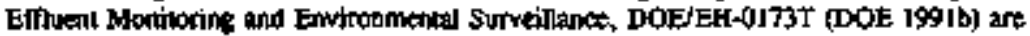
addressed in Table 96. 


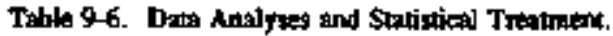

\begin{tabular}{|c|c|}
\hline $\begin{array}{l}\text { Sumamary of data end antisticul trealment } \\
\text { requinemers }\end{array}$ & $\begin{array}{l}\text { WHC-SD-CPQQAPP-003, REV. } 1 \\
\text { (WHC 1994d) }\end{array}$ \\
\hline 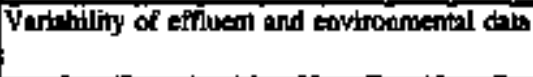 & 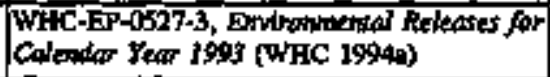 \\
\hline $\begin{array}{c}\text { Sunmarization of tain and uesting for outhers } \\
\text { : }\end{array}$ & 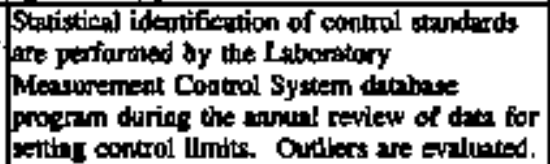 \\
\hline Jreatmenl of significant fogures & $\begin{array}{l}\text { WHC-SD-CP-QAPP-003, RAv. I } \\
\text { (WHC J994d) }\end{array}$ \\
\hline Parent-decay product rolationships & 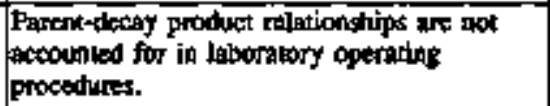 \\
\hline 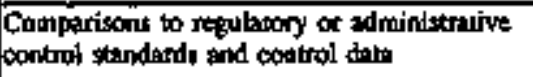 & $\begin{array}{l}\text { The 222-S/Contriat Laboratory participates } \\
\text { to the EPA Intra Comparison Program }\end{array}$ \\
\hline Quality assurence & $\begin{array}{l}\text { WHC-SD-CP-QAPPAOS, RAY, I } \\
\text { (WHC 1994d) }\end{array}$ \\
\hline
\end{tabular}


WHC-EP-0497, Rev. 2

This page intentionnlly left blank.

,

\section{$9-10$}




\section{NOTHFICATION AWI REPORTTWG RDQUIREMIXNS}

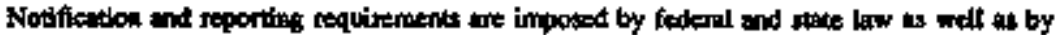

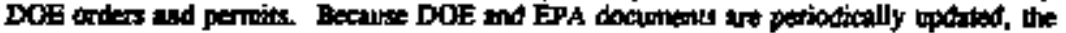

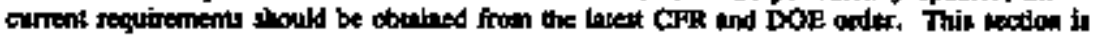

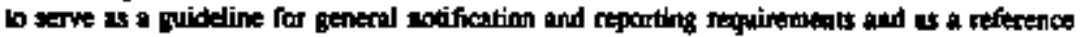
to the warces where specific informtetion mag be foend tor federal, sale, and DOE recpivitments.

\subsection{OCCUMRENCE CATDCORZATHON, NOTIFCATION, AND REMRTING}

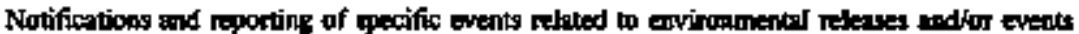
involving efluents andior kazundous naterials shnll be made in secordance with DOE Onder 232.1 (DOE 19\%6) and DOE Mameal 232.1-1. Impkementints the ofders is tocomplizhed vis WHC-CM-1-5, Standand Operatisg Prastices Section 7.1. Specific inpiementadon, where

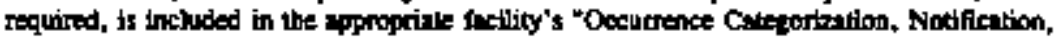
and Reportins:" procedure. Implementing environmental limbs aud tequimements is found in WHC-CM-7-5, Entrousterrel Complatse.

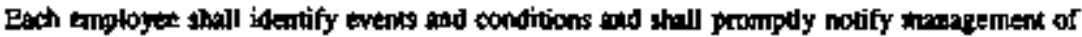
wach aceurratios.

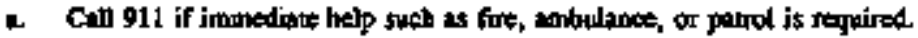

b. Call 373-3800 (the Fand Opentions Contex) if assisturee odther then firc, ambulanee, of parrol ts required.

c. After requesting necessary outsidp usiance, the employee atall netify his or her sapervisor, tho shall notfy the feclity manager, the building emergency firexior, and the Oecurrenes Notifleation Center (376-2900).

Opentions personel shall take appoprinte inneciate axtian to stabilize or retarn the Feilityfoperstion ba sefe condibon. Actions baken in response to non moutine releases. as evideaced by high sample Inoults firon liquid and enseoves effluent sampling, are docoumented in WHC-CM-7-5, Entironnentol Compitance.

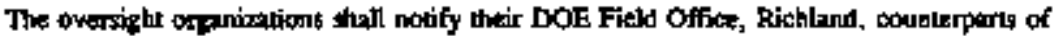
the event after receiving aotifications from, and discussing the event with, the facibity manaser. 


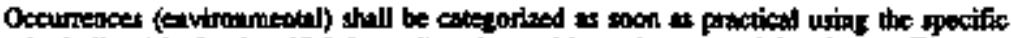

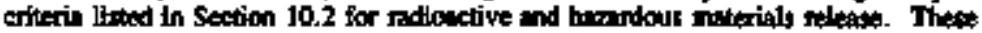

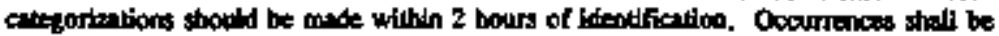

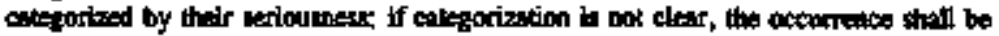

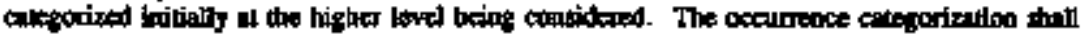

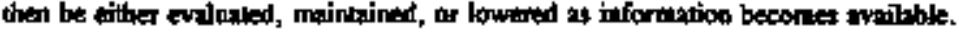

\section{OCCURRDNCT CATEGORFATPON}

The fobowine criverh for cakgoriration of ocearrences are estobllshed in WHC-CMI-1-S,

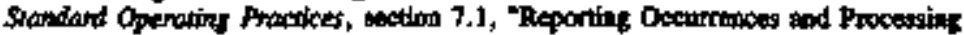

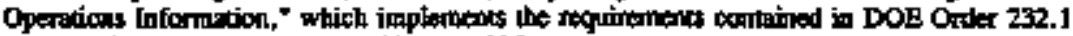
(DOE 19\%6) and DOE Manuad 232.J-J (1995).

\subsubsection{Red'antive Releises}

\section{to,2,1,1 Uno:all Ocoumence.}

- Relesse of raficonuclide miterial that violates environmemtal nequirements in foderal permils, federal regulations, to DOE tonderds.

- Release below levels which requires inmediac (hes than 4 hours) reporthe bo

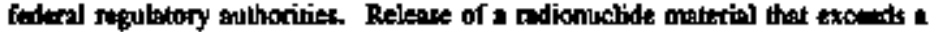
fodscrlly permitiod nalease by the tmount of a CERCLA feportable quantity or,

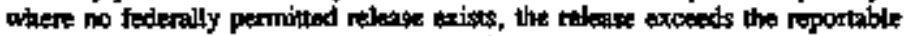
quantity or triggers pexific extion levels for ol outside arency.

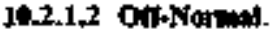

- Any release of adiomeclide material bo contralled os uncontuolled ares that is

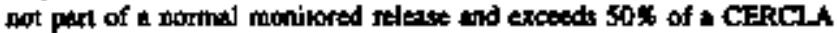

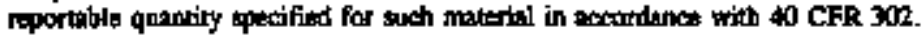

- Any controlled melease of rodionuclide material thal occurs as a monitored part of normal opentions thet exceeds whal hiskationt hatn and/or andysis show is expecied as a result of normal operations.

- Any monitored facility or site bouadary whent exposure of concentrations exced whal historictal taip andfor analysis show is expected as a refull of aormal operations.

- Any debetion of a radhonuclide in a saitary or thorm sower, walte or process

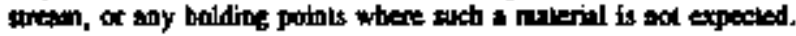


- Any controlled, uncontrolled, or necidental relowte that is not thastified as in

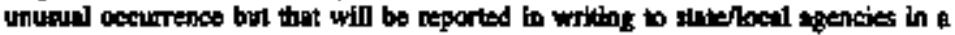

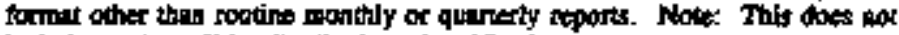
include routise offeive distribution of notification noports.

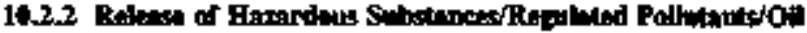

\subsubsection{Unosial Decurtenct.}

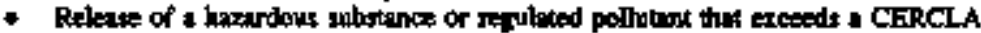
reportable quintify in accordince odit 40 CFR 302 and 40 CFR 355 for

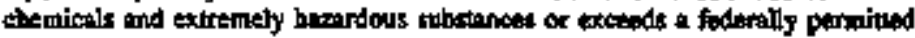
riters by a toputable quantity.

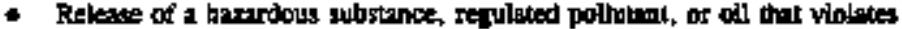
eavitonmental requirements in federal permily, sederal negulations, of DOE shindarts.

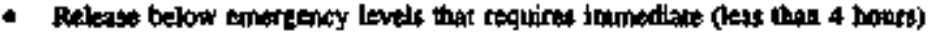

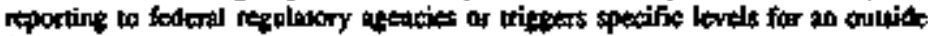
feteril agency.

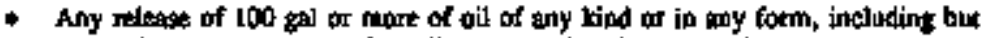
not limited ko, petrolcum, fuel oil, sludge, on refure, and oil mixed with wroles other than dredged soil putside of a permitted conbinment area.

\section{J0.2.2.2 OrT-Normul.}

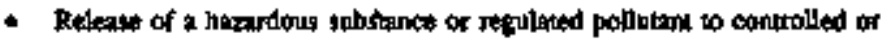
uncontrolled stras that is not pant of a nomml, monitored relesse and exceds 505 of a CERCLA- reportshle quantity as pecified for such moterial in scocordance with 40 CFR 302

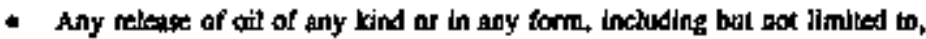

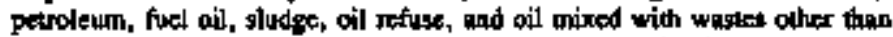
dredged soil outside of a permitted coatviament area which is less than unutial occurrence levely bul greater than 42 eal.

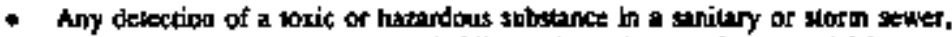
whste or proctigs trotam, of any holling polms whene such a material is not

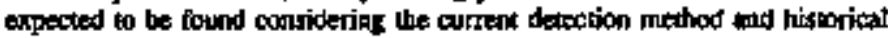
detextion tielhod used. 


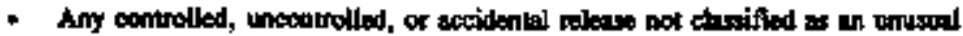

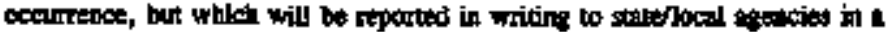

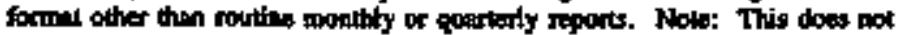

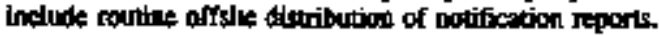

- Any controlled relere of haxantonsiregulated material that ocourt as 2 moniloted

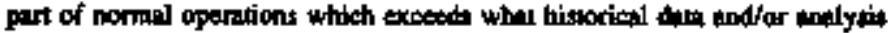
dows is expected is a resull of octmal pperations.

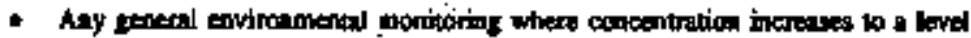

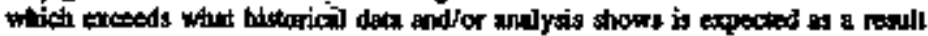
of nocmel operations.

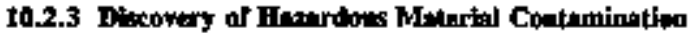

Due to DOE Operitions

\subsubsection{Unngial Oecumence.}

- Discovtry of on-site of off-site contamination due to DOE optrations which does

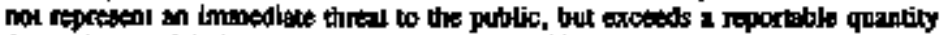
for such matterials in necordance will 40 CFR 302.

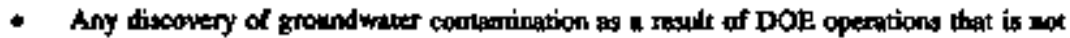
part of an existing plume previously dentified elliter in an anmegl sepoit or in any CERCLASRCRA activity in report.

\subsubsection{Oft-Norom.}

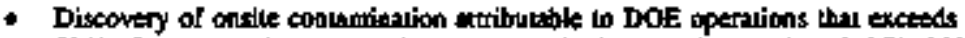

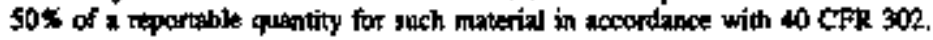

\subsubsection{Aureenetm/Compliance Actlvitis}

\subsubsection{J Ott-Normal.}

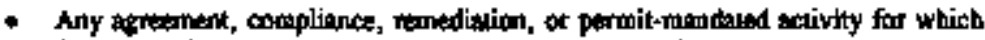
formal notification of enforcement bas been received from the relevanl refulatory agency that a sitedfacility is consthered to be in soncomplance with schedules or

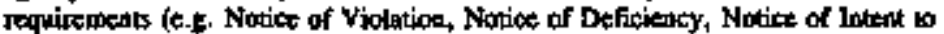
Sue, and any other types of enforcentent actions). Noik: Formal notification. must be nectived by Westinghouse Hanford Company in writing. 
- Any oxcumence under agy apreement of compliance area that requitres

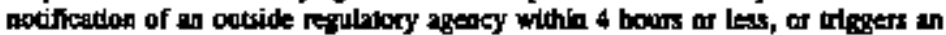
ootside rejulalory ajency action kevel, or oblerude tndicales specific

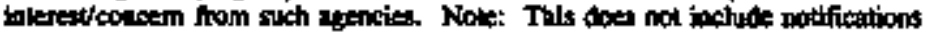

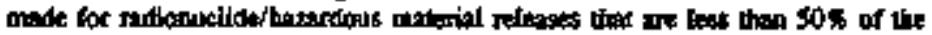
Itipontalike quamtity as spexified in 40 CFR 302.

- Any occorrence under any agoement of compliance area thit will be reperied to

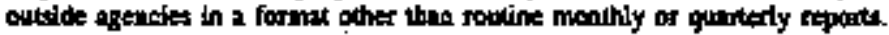

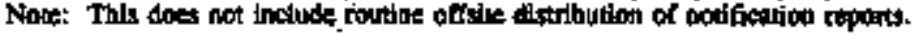

\subsubsection{Eeoleyfeal Resouross}

\subsubsection{Unnaul Occurrence.}

- Any aceormence cauping significant ingact to ung ecological rosowed for which the DOE is a trustec (j.e destroction of a griticl habiht, damage wo an historicollfariheological tite, of damage to wethands').

\subsection{FETERAL REQUTREMIENTS}

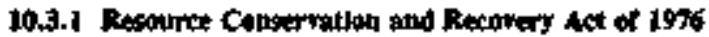

The RCRA Jequires bienniv Jeports to be pubntitted to the rejiontal abninistrilor of EPA. 40 CFR 262, Subpart D secs forth the neporting requitements for genterabors of haverdous

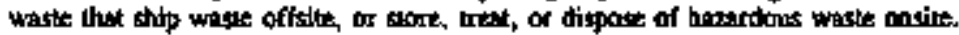

Owrers or coperators of traturenl, startge, and dispost focilition mast comply will the teporting गफ्quirements contained in 40 CFR 264, Subpart E and 40 CFR 265, Suthpart E.

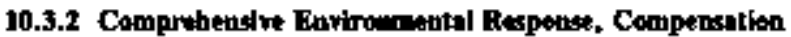

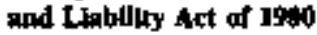

The 10 CFR 302 contains reponthle quantitles and notifleation requirersents for releases of

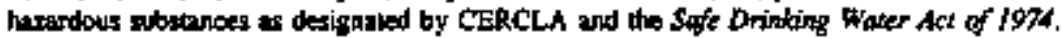

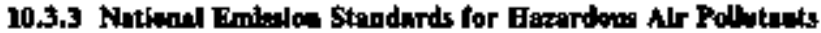

Compliance and reporting recprivement far DOE facilitios emilting radionuchides other than

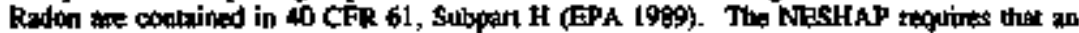

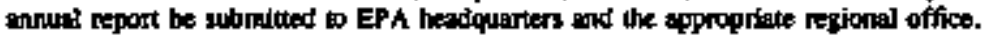




\subsection{BTATE REQUIRDMENTS}

\subsubsection{Cenerulne Reporting}

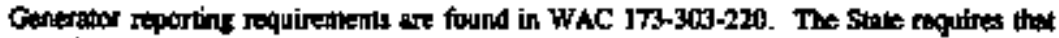

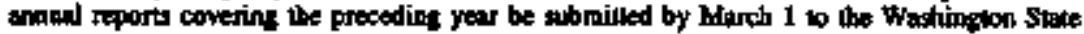
Departident of Exology.

\subsection{Focility Reparilue}

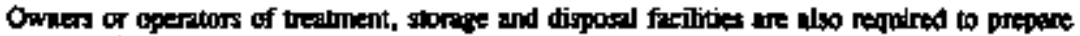
and submik etenull reports. These must be submilted by March 1 and covver facility antivities for the prewhous year. The specific concent requirements ane spectfied in whC 173-303-350.

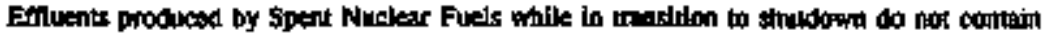

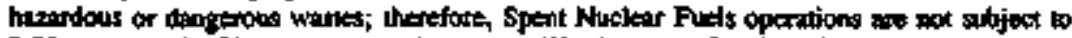
RCRA of WAC 173 ropurting regutrements. Westinghouse Fenford Compeay would only

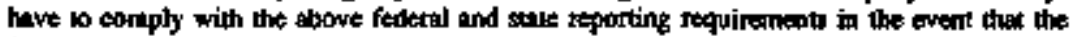
farility opertions were to change, and discharges (eithor likuid or geseous) from the Spent Nucleas Fuels facility contained a hazardous of dangerous components.

\section{S U.S. DEPARTMENT OF ENBRGY REQUIREMLNTS}

\section{5,1 DOE Orike \$40.1, Chopter D. "General Emriromentat Protection Propic. - Notiflentlos and Reports"}

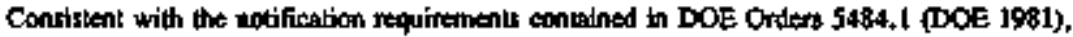

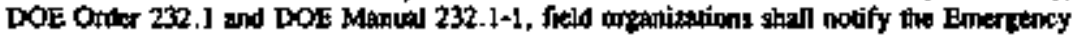
Operations Cesier of the signdfiesnl nonroutine releases of any pollubal os hazerdous substance.

All DOE facilities that conduct significenl tovirtimmantal protection proprams thall prepare in annual site envirciemental repon. Annusl aummary reparts on envinonmental occurrences

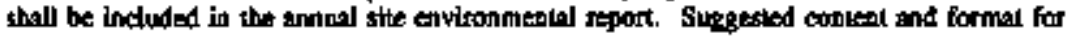

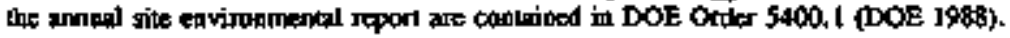

DOE Order 5400.1 (DOE 1991) also requires thal a radioactive effluent and criste discharge data repon, covering the previous calendar year be abmitted to the Idaho National Engineering Laboratory (INEL), in Idaho Falls, Idibo 83415, by Aprit 1. Uinplanted releases of ndiosctive material in effluents, whether onsite or of fsite, shall also be reporked. 


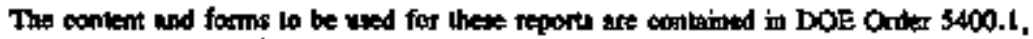
Chepter II (DOE J988).

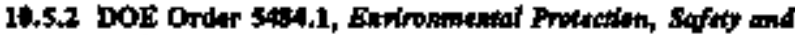

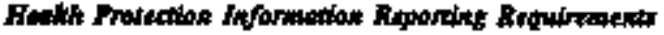

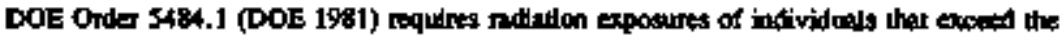

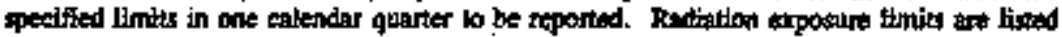
in Chopter II of this order.

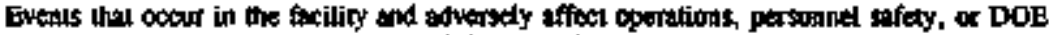

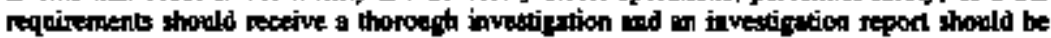

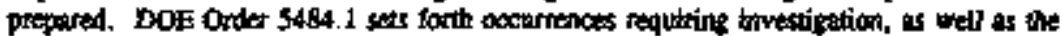
imverigation requinemenls ss determined by the severity of the ocournesce, imvalightion repod format, and contenl outlines.

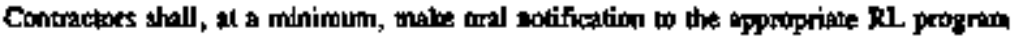
division or offec, to the Public Affirs Office, and to Sutaty and Quality Ausurince (SOA)

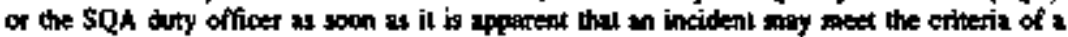
Type A or Type B oceurrence. A listing of occurrences nequiring a Type $A$ or Type $B$ tavestigation it contatred in Chopter 1 of DOE Order \$4B4.L (DOE 1981).

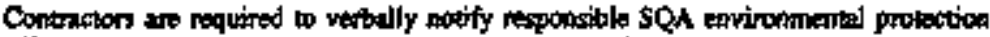
offieisls within 24 hows of becoming anse of any of the follows cocumences:

- Violution of applkable federal, smbe, or locel pollution contenl tandirds and ticyuitiments

- Any tomoompliance with the'verms andior condilions of an existing Katlonal

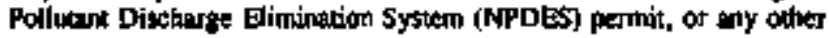
envirummenuld-protection-bated permil or formal agteeneol with an applicable regulatory body

- Any gusous or liquid ratiolopical effluent roleast thal exced DOE repulirements andfor conuractor-apecific radiological release concentration guldes.

Following vertal aobifications, writlep reports must be submitted according to procedures in DOE Crdes 232.1 and DOE Manul 232.1-1. 
WHC-EP-049, Rov. 2

Thit pape intentionetly left bunk. 


\section{INTERACT WITH TIE OFERATHONAL ENVIRONDIENTAL MONITORING FROGRAM}

\section{1 nEgCrIPTION}

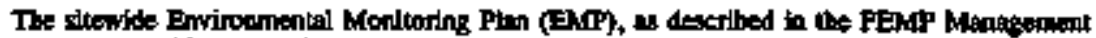
Flan (WHC 199]c), consists of two distinet bot related components: tovitonmentol

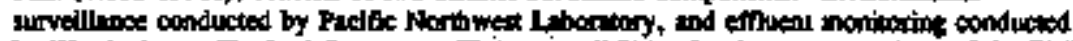

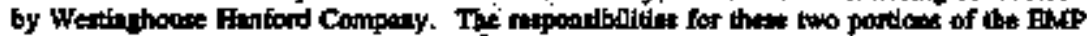

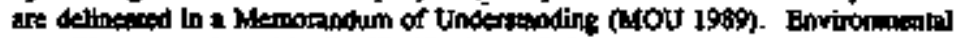

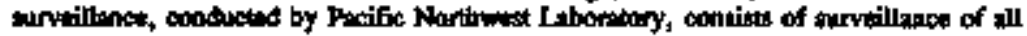

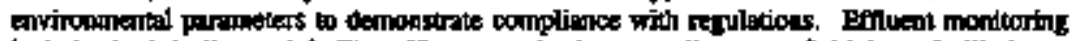
includes both in line and facilty effiluent menikoring al well as near-field (aser-faclity)

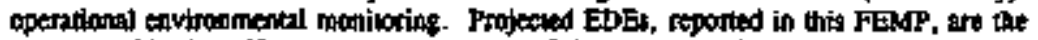
peoducts of in-ban offluent moniloring. Near-field moaikaring is required by WHC-CM-7-5,

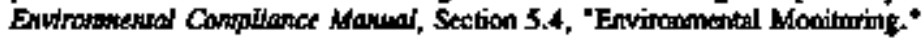

\subsection{MUROSE}

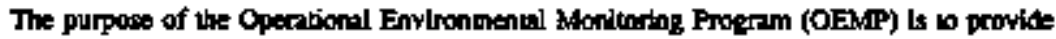

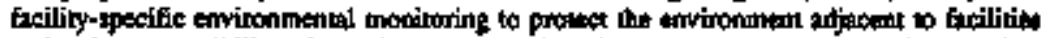
under the respontitility of Westinghouse Hanford Corppony and ensure coraptiance with Westiphouse Hanford Company requitements and local, stale, and federel envimonmental regulations. The objectives of the OEMP are w evahuse the followtog:

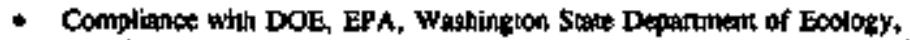
Wastingten Stote Department of Healih, und internal Westingtowse Hanford Compeny arvirosmental refiation protection requiremenls and guides

- Periocmance of tadimative waste catinement syaseons

- Trends of redicactive materials in the environment at and adjucent bo nuclear focilities and waste tisposal siber.

Specifically, the OEMP is develnped to:

- Monitor all loactive, extritine, and aew lon-level waste disposol sites to usess boh madiological and napradiological harainds (DOE Order \$230.2A [DOE [990d]] 


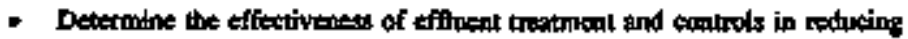

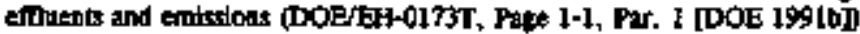
(DOEJEVI 1830-TS [DOA 199]a])

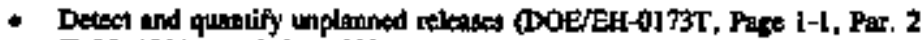
(DOE 19913) ( 10 CFI 302) (WAC 173-303-145) (DOE 5000.3A [DOE 1990)] (DOE S484.I JDOE I9:I])

- Montior fupitive entiksicint and diffinso sounces from contaminated areas for

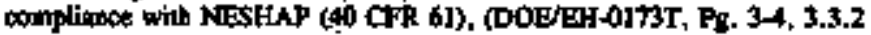
[DOE 1991b]). Tancic Au Brisuions Imwentory (40 CFR 265, Subparts AA and BL3), State Operating Permit Progrm (40 CFR 70), and Soune Registrotion (WAC 246-247).

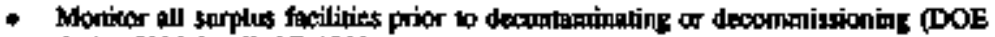
Onlü \$82022A [DOE 19900]].

- Monitom now and txisting sites, processes, and fucilities for potential impacts and

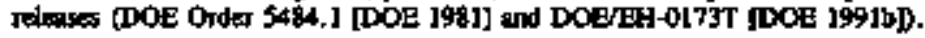

- Monior and astess rationative conbarinetton and potemtal expogine to employes and the public (DOE Ond $\$ 400.1$ [DOE 1989] and \$400.\$ [DOE 199(女)].

The parpoes and fustiflesion for the DEMP is contained in WHC-CM-7-5, Emwirananted Conpilance. The primary justification for the OEMP includes the following:

- The OEMP provides a level of assurance lo Westinghoose Herford Company that the effuent and contamination controls for the various facilities and waste tiles are effective.

- The OEMP monitors a diversity of operations, activities, and projums managed by zeveral different Westinghouse Hanford Compony organizalkons. Axcordingly, the program direction and theregrition function performed by

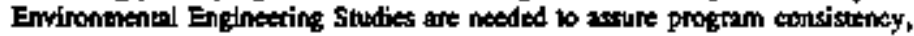

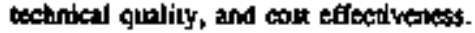

- A secondary aspect of the OEMP is additionnd asurance beyond thal provided by the Oectapational Eseallh and Sufery Progtam that it is soif to work onsite and that visibes can sefely tour the sile. 


\section{Basis}

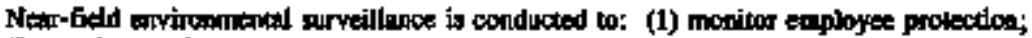

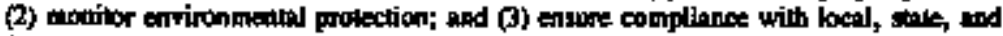

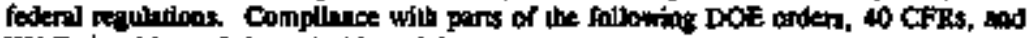
WACs is adresed throggh this activiky.

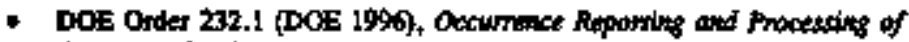

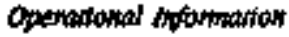

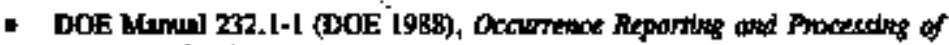
Operational lnfommotion

- DOE Order 5400.5 (DOE 19903), Radtation Pnutection of the Public and the Enwinoment

- DOE Onder S4D4.1 (DOE 1941), Prosecrion. Safay, and Bealah Provection

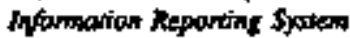

- DOE Otder 5820.2A (DOE 1990d), Rodianctive Waste Hanageserst

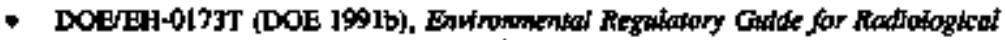

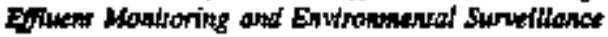

- DOE/EV/1830-TS (DOE 19918), a Gadde 20 Roduting Radiation Expoteste to As Low As Rearanably Achieneble [ALARA]

- 40 CFR 61, "National Emistiban Standards fur Harardaus Aut Pallutants"

- 40 CFR 70, "State Operating Permit Progrims"

- 40 CFR 265. Subpert AA and BI3, "Interim Satus Standards for Owners and

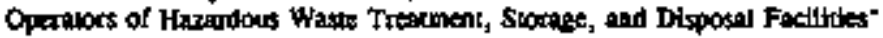

- 40 CFR 302, "Designtion, Reportable Quantities, and Npification"

- WaC 173-303-145, "Dangenous Waste Reguffions (Spits and Discharges)"

- WAC 246-247, "Radiation Protection-Air Emissions." 


\subsection{MEDA SAMPLED AND ANALYSES PERTORMED}

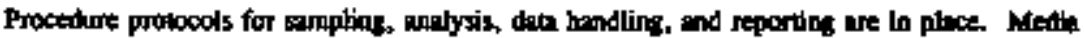

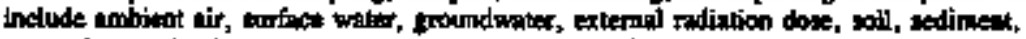

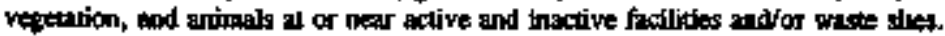
Parametert moteibored inchade the following, is needed: pH, water terperanis, cadionuctioes, radiation exposure, and haxprdous consutheals. Animals thal ate not

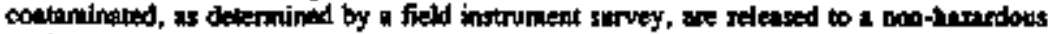
धाvironarel

\section{1.\$ LOCATIONS}

Samples ane collected from known or suspected effluent pothways \{e.g., dowmuind of potental rekasses, liduid sireans, or prowimal on releave points). To avold duplication.

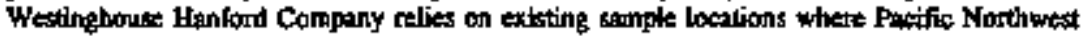
Laboratory has previously oubblighto sample vites.

Surveys to detect surface sodiological contamination, scheduled in WHC-SP-DO9B-S (WTHC 1993), are conducted near and an liquid watte disposal sites (e. f., cribs, treaches, drins, retentioe betin perimeters, pond perimeters, and iftch banks), salid waste disposat

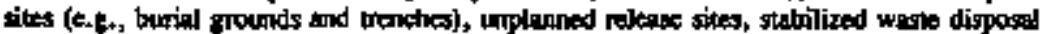
sires, rads, ant" firebreals in the Operations Areas.

\subsection{PROGRAM REVIEW}

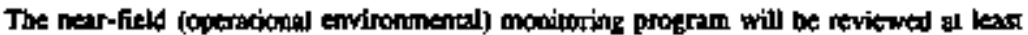
monually to determine that the appropriate effunents are tring monitared and that the monitor locations are in position to best dekmiti: potential rebeases.

\subsection{SAMFLER DESIGN}

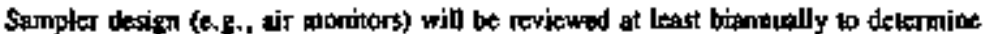
equipment efficiency and compliance with current EPA and industry (e.g., ANSI and Americton Society for Testing and Maucrials) standards.

\subsection{COMDMNACATtON}

The operatioss and engineering contrekr and the researeh and developmenl contrector will

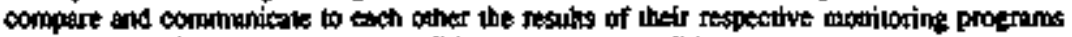

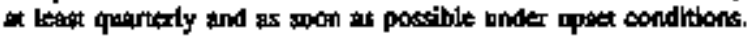




\section{RETORTS}

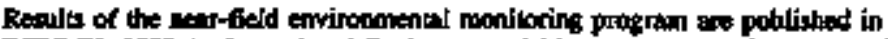

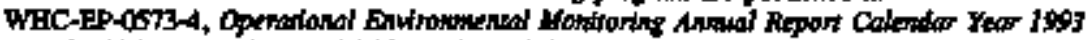

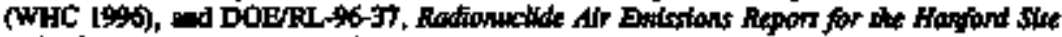

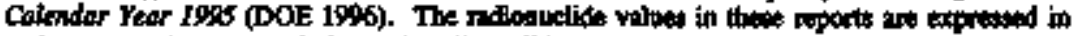

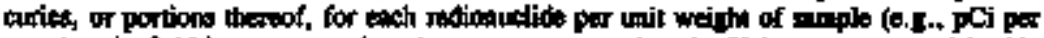

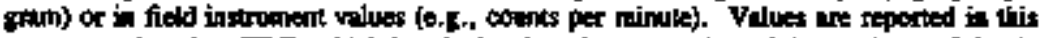

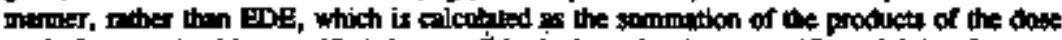

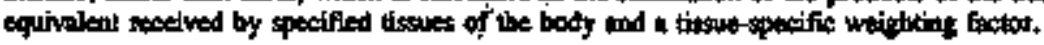


WHC-EP-0497, REN, 2

This pare intentionally left bank.

I 


\subsection{QUALITY ASSURANICE}

\subsection{FURPOSE}

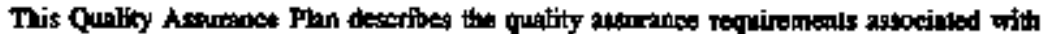
implementing FEr.Ps. The phe bentifind the FEMP notivities and usizas the approprite

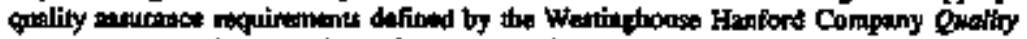

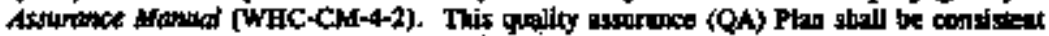

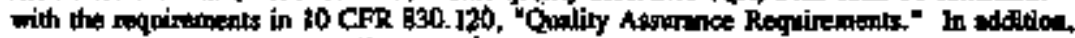
QA requirements in 40 CPR 60. Appendix A, "Reference Methodologles" shall be

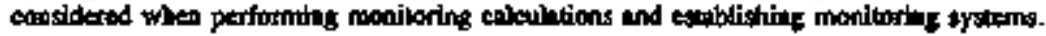

\subsection{OAECTVE}

The objective of this plan is to provide a doctmented QA plan descriting QA requirements fir facilitien implementing the FEMPs.

\subsection{RDQUIREMIENTS}

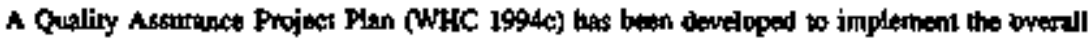
QA program requirements defiued by WiC-CM-4-2. Tve QAPjP applies spedfically to the

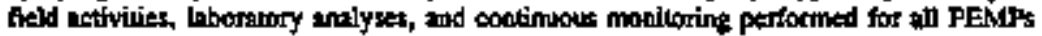

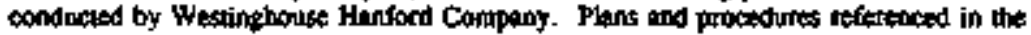

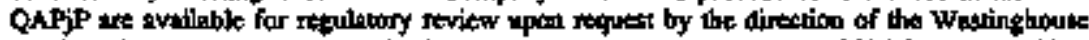
Horford Condrany Effhent Monitoring Manaser. A QAPP (WHC-EP-0536-3) (WHC 1995) for radiosclive aitbome omisgion monitoring was propared to address the $Q A$ elements of 40 CFR 61 and wos subsnitted to the EPA. 
WHC-EP-0497, REV, 2

Thd gage intenttontally loft blank 


\subsection{INTIRNAL AND EXTERNAL FLAN REVIEW}

The Genemi Fantroninented Protection Prograri, DOE Order 5400.1, Chapter IV.4 (DOE 1988), requltes tha the FEMP be teriewed antrilly and updated every there yean.

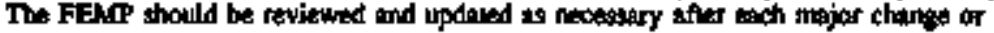
modification in the facility processes, facility strocture, ventilation and liquid collection systems, monitoring equipinent, wiste treatment, or a ripoditeanl change to the Safity

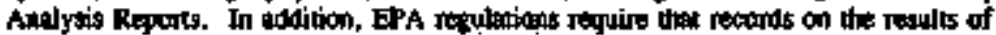
adioative eirterne embsions monitoring be maintained onvile for five years. Operation

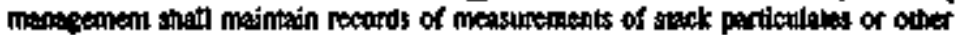
nonndioactive lazundous polbutant emissions for three years. Pacility oporntors will have to

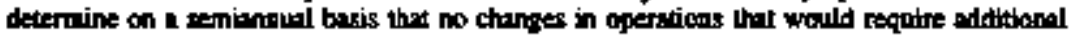
mansuremitons have docurted.

Westingkouse Hantord Connany Effluent Monitoring (EMO) prepares an whroel efthuent dischartes n-pont for each area on the Hunford Sile ko cover both girborne and liquid relese pallhways. Alutough the repor is based on the calendar year, the enizsion limits apply to

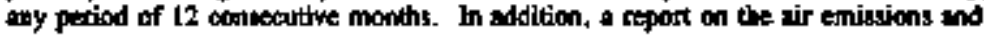

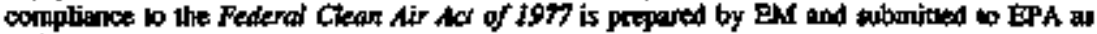
meth $\mathrm{DOOE}$.

Facility murazement is to obain the EM function's approval for all changen ko the FEMPs.

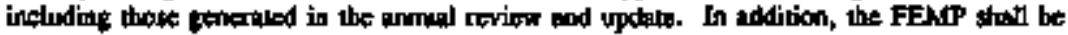
reviewed by othen if detorauned by EM. 
WHC-EP-0497, Rev. 2

Thes page intentionally left blenk- 
WHC-EP-0497, Rev. 2

\subsection{COMIPUANCE ASSESSMENT}

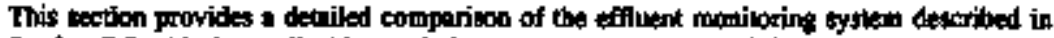
Soction 7.0 with the rpplieable tegulations prosented in Section 3.0. Bosed on the

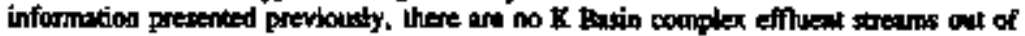

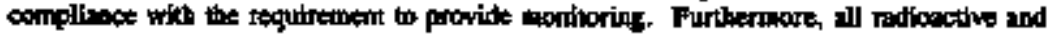

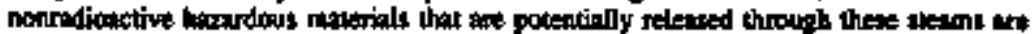

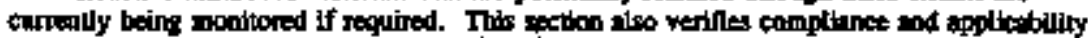

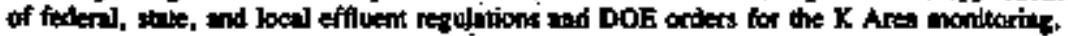
Where a poienthl environnentel monitorimg problem exists, an cyaluation of the extsting

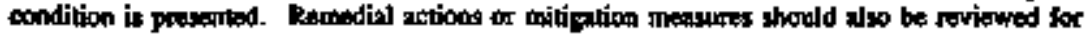

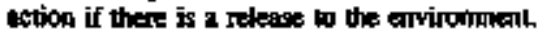

\section{1 las Ka AND Jas RW RASTNS}

The sanple probes for the basin area erlaust consigt of a single probe near the four exhauds

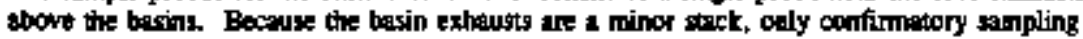
anslystit is tequeted. Confirmalory sempling will be done by contimuotss samapling when the

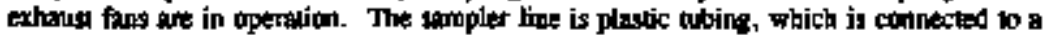
vacoum pump.

\subsection{LFW KT MAIN FLOOR A-POOT LEVEL)}

The tanpie probe for the 1706 XE is appropriale for the size of the pack and is localed

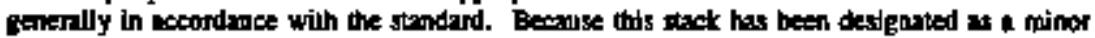

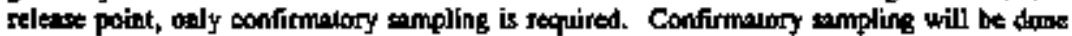

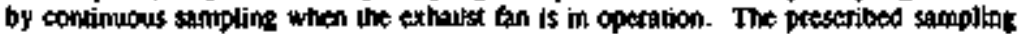
froxuency and daration are appropriale.

\section{4_3 1746 KE RASEMENT (4-METER [13-FOOT] LEVEL)}

This venthation system has not been operaled sine 1989 and there are no plans to operate

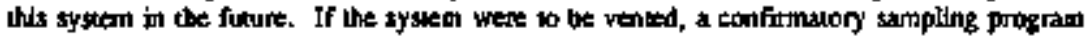
would need to be estoblighed to sample minor stacks.

\subsection{KE SUE-BASEMENT (2-METUR [27-FOOT] LEVEL)}

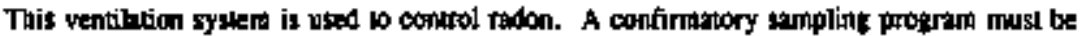
estublished if this system conthues to operate. 


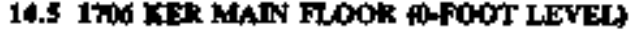

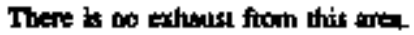

\subsection{M6 KER A-MITER [27-FOOT] LEVEL]}

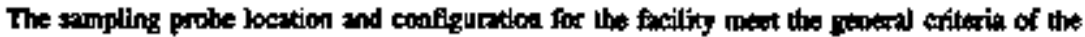

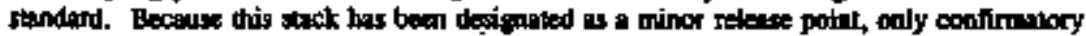
sempling is required. Confimatory sampitag will be done by contimuous sanpling when the exhust fon is in operstion.

\subsection{M KER QT-FOOT LEVEL) TUNNEL EXHAUST}

This rentilettoe system was used to control radon, and is nol th operation as of 1994.

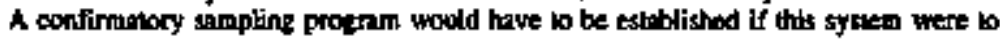
operite.

\subsection{KEK}

This tyatem is operating al this time and coptirand to be a miage stock.

\subsection{1\%00 KE OUTFALL (0.4)}

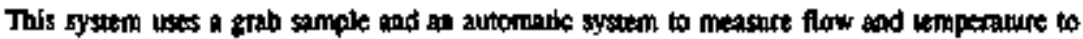
moct the NPDES requiremeols.

\subsection{KE OUTFALL (003)}

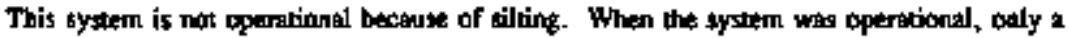
Jrab sample was required. 


\subsection{SUMMARY AND CONCLUSTONS}

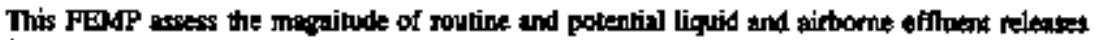
from the $\mathbf{K}$ Nrea to determing the conpitance of emuent montlocing sybteml and samplins:

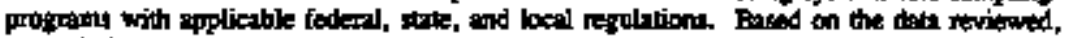

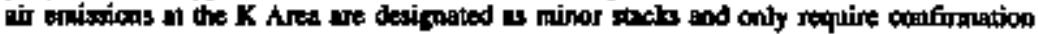

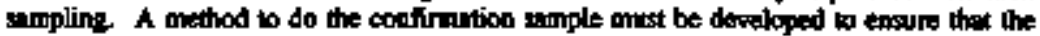

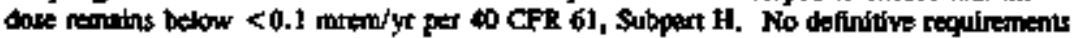
are lisled in 40 CFR 61, Subpert $H$ for performing periodic confirmatory neserurenents.

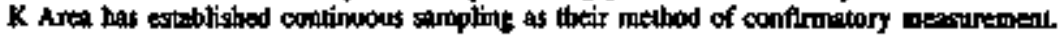

The NPDES oudfalls mete the requiremeals. 
WHC-EP-0497, Rev. 2

This page igtentionally left binak.

$\therefore>$ 


\subsection{REFERTCES}

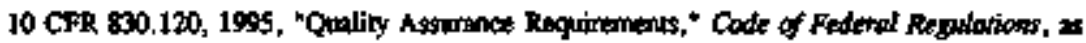
areended.

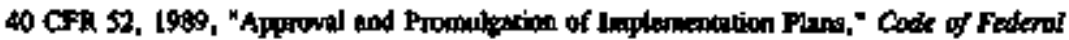
Regutetions, ts amended.

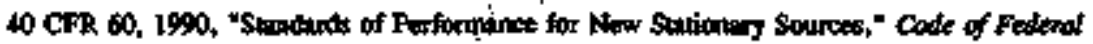
Regulators, as imended.

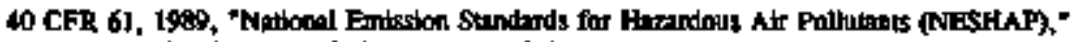
Cade of Fedient Regulations, as nmtaded.

40 CFR 70, 1992, "Sube Dporating Permit Pagran," Cade of Federed Rezwladors, ot anonded.

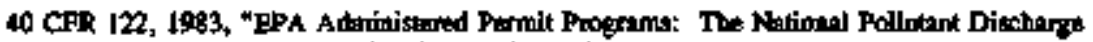
Elminition Sy:en," Code of Fedenat Begulation, as uneaded.

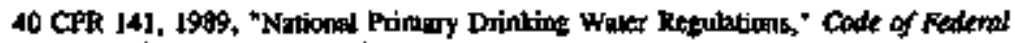
Regulations, gs amendad.

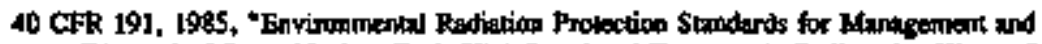
Dispoesl of Spen Nuclen Fuel, Figh-Lovel and Tranumie Rediosctive Wesies," Cade of Federat Regulations, as uminded.

49 CFR 261, 1989, "tampification and Listins of Fazvdount Wasts, Code of Federal Regulations, a anended.

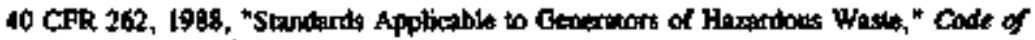
Fedenal Regalarious, as anpoided.

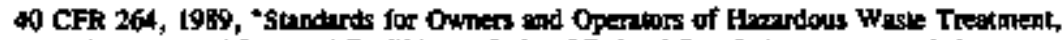
Storage, and Dipagal Facilities," Code of Fedened Regulatians, as amended.

40 CFh 265, 1989, "Iakerim Staus for Owhers and Operaks of Handrous wasto Treabment, Storafe, and Disposel Facilitien," Conde of Federel Regulatow, as anconded.

40 CFR 302, 1991, "EPA Desiguadon, Reportable Quantilies, and Nọtifiection Requlnaments for Fingardous Substances Uader CERCLA." Code of Federad Regulations, as amended. 
40 CFR 355, 1987, "Superfula Amendments and Reuthorizaticat At of 1986 (SABh)

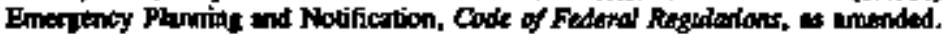

40 CFR 401-77], 19\%0, "Efiloent Guidelines Stodads," Code of Fodon' Reghlatons, at arended.

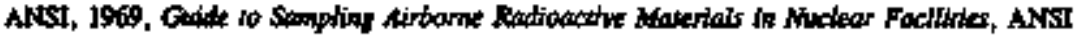

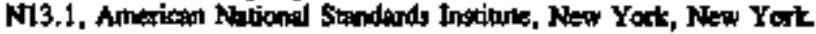

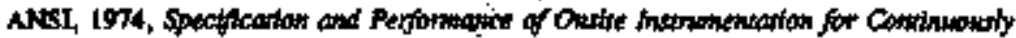

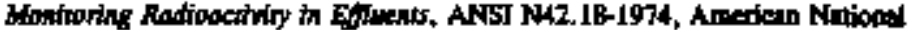
Standirds Indtivk, New Yors, New Yort.

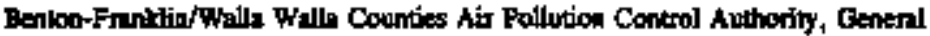

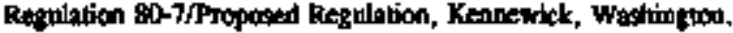

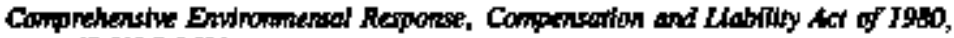
42 USC 96Bl * :

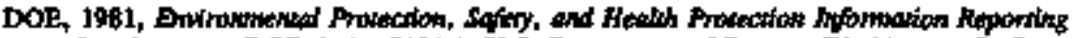

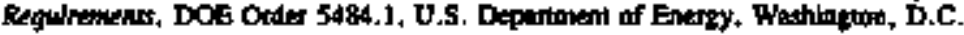

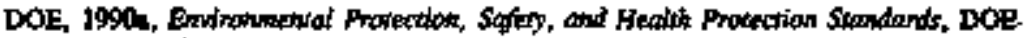
Gider 5400.5, U.S. Department of Energy, Wastopton, D.C.

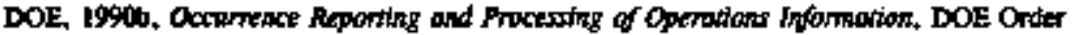
\$000.3A, U.S. Departinent of Energy, Washingron, D.C.

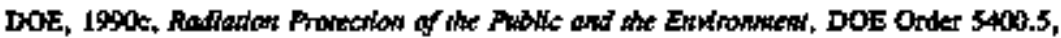
U.S. Depertment of Enetgy, Washington, D.C.

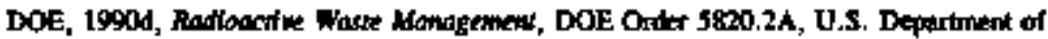
Enerzy, Whshington, D.C.

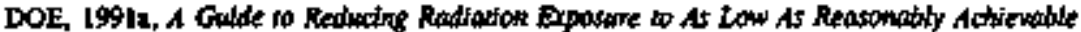
(ALARA), DOESEV/1830-TS, U.S. Depatument of Enercy, Wahington, D.C.

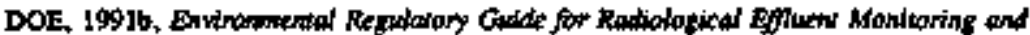

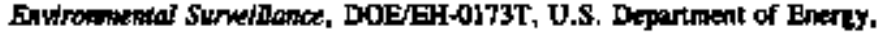
Washingtoo, D.C.

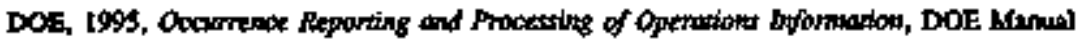
232. I-I, U.S. Department of Energ, Wathington, D.C. 


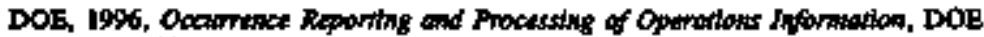
Order 232.I, U.S. Deperinem of Energy, Whinington, D.C.

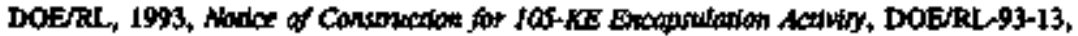

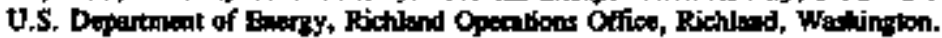

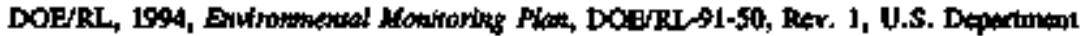

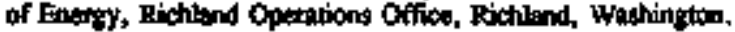

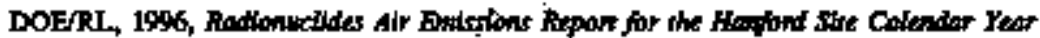
IS\%5, DoE/RL-S6-37, U.S. Deparintent of Energy, Richland Operations Office, Richlund, wastington.

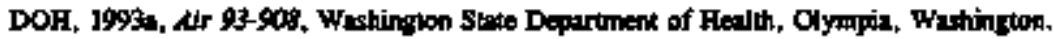

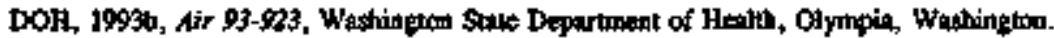

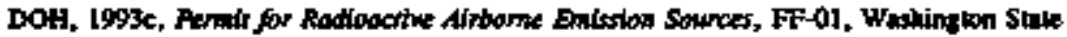
Departmenl of Healt, OHympis, Wushiogton.

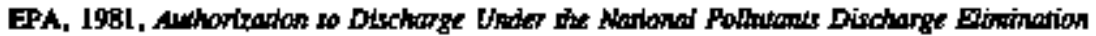

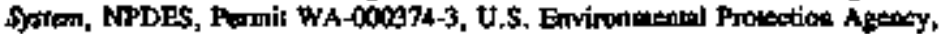
Wathing ton, D.C.

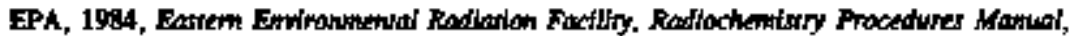
EPA+520/5-84066, U.S. Envigonnentol Protection Ajency, Wushington, D.C.

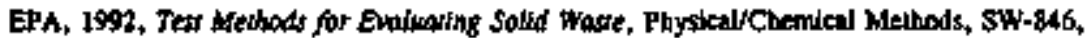
U.S. Environmental Protection Agency, Washington, D.C.

EPA, 1992a, Atothorizarion to Ditcharge Under NPDES for Sromavace Dichanges

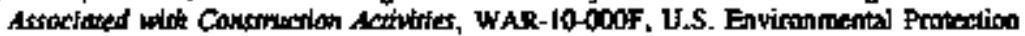
Azency, Wuhington, D.C.

EPA, 1992b, Awhorizaston io Discharge Under NPDES far Stommater Discharges for Indusurled Actidules, WAR-00-000F, U.S. Envtronmental Prokection Agency. Wastinglon, D.C.

Federal Cean Ali Aat of 1977,42 USC $7401 \mathrm{et} \mathrm{seq}$.

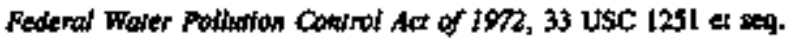

MOU, 1989. "Memorandun of Underatendiag." Pacific Notulwes Laboratory und Westing boose Hunford Company, July 1989, Richland, Wathingtam. 
Nupier, B. A, R. A. Puloguin, D. L. Strenge und J. V. Raractell, 1989, GEvert - The

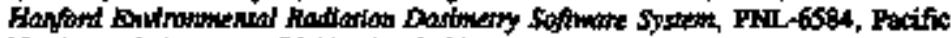

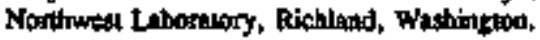

Resawre Consarwation and Reconery ACt of I976, 42 USC GAO1 et sey.

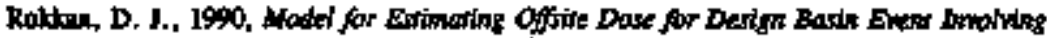

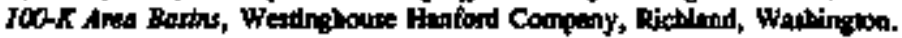

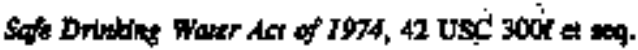

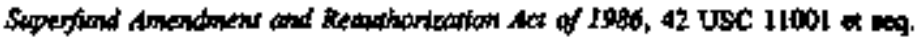

WAC 173-200, 1990, "Watr Quptiry Spacteds for Grond Wotho of the State of

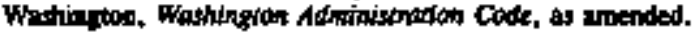

WAC 173-216, 1994, "Stale Wate Discharge Pemil Prograin," Woshingras Adwindserarive Code, un anduce

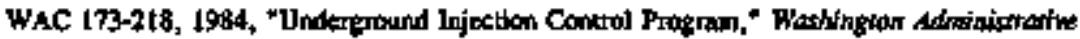
Couk, ss amended.

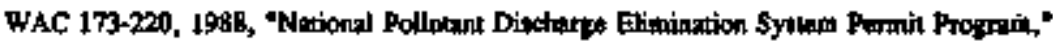
Washington Adindaisrotive Code, as anended.

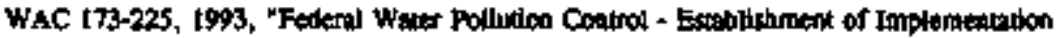

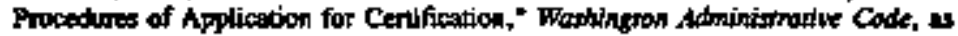
areaded.

WAC 173-240, 1990, "\$ubuistion of Ptans, and Reports for Contituction of Waste Wator Faciliter," Waskingrow Adwintismalue Code, as amended.

WAC 173-303, 1991, "Dangerous Waste Rezuhtions," Washington Adersinisprarive Code, as amended.

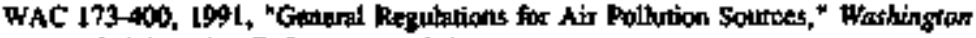
Administrethe Cade, as amended.

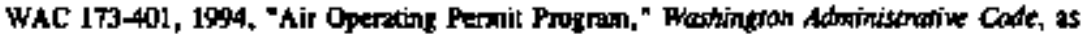
unterted.

WAC 173-461, 19\%l, "Conkrols for Nkw Sources of Toxic air Polluants," Faskingeow Adininistrathe Couk, ss amended. 


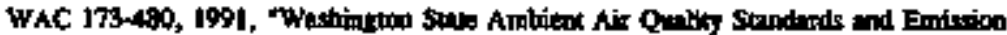

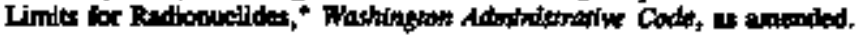

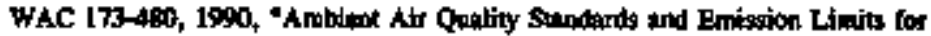

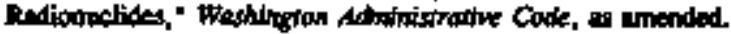

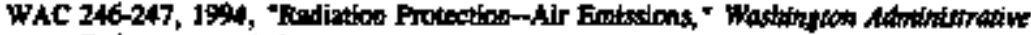
Codt, is imatid.

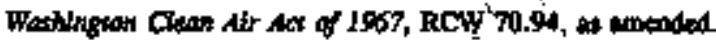

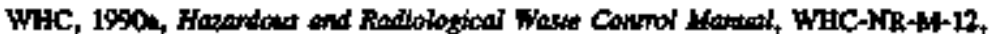

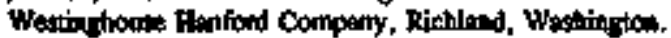

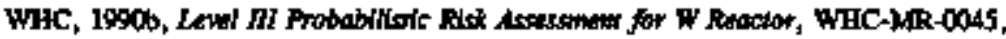

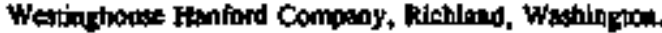

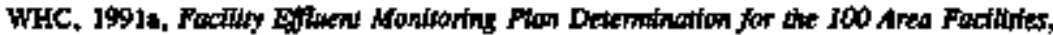
WHC-EP-0439, Weotinglous Handord Conpany, Richland, Wathington.

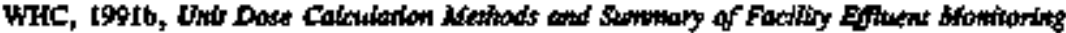

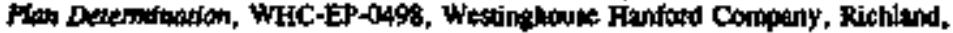
Wathingtion.

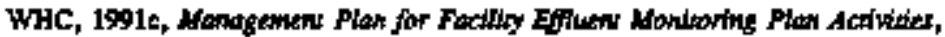
WHC-EP-A41, Westinghouse Hanford Company, Rishland, Wallington.

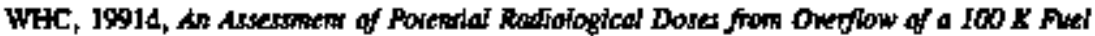
Starage Bails, WHC-SD-NR-TA-011, Westinghouse Hanford Conpany, Richlnd, Washingion.

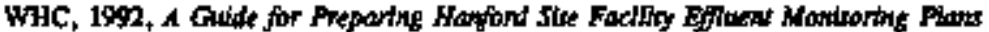
WHC-EP-0438-1, Wetinghouse Henford Company, Richland, Whthington.

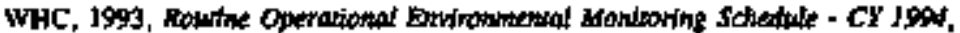
WHC-SP-0098-5, Wextiphowse Eianford Compary, Richland, Waghingtoa.

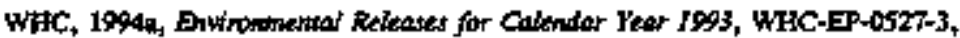
Weatinghouw Hanford Company, Rishlont, Washiogten.

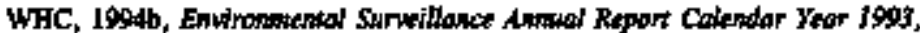
WHC-EP-6r3-], Wetinghoust Hanford Compay, Richland, Washington

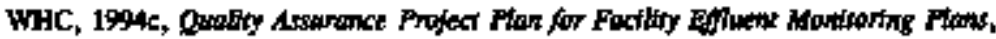

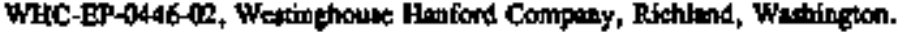




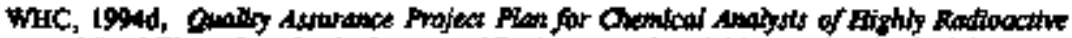

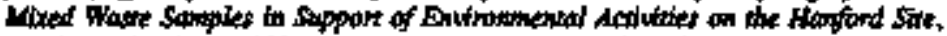
WHC-5D-CP-OLPP-003, Rev, I, Wentinghouse Hantort Caripany, Richlond. Wastingtos.

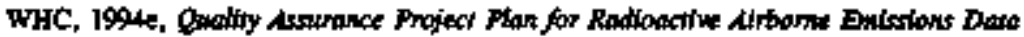

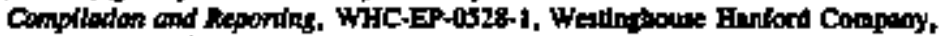
Richlend, Wathington.

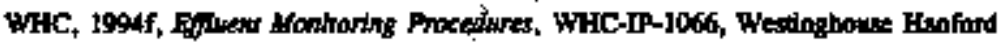
Comproy, Richland, Washingtoin-

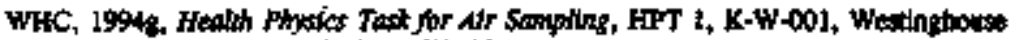
Hantord Company, Richlend, Washington.

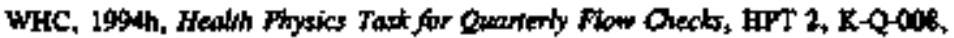
Westinglouse Hanford Compory, Richland, Washingtoh.

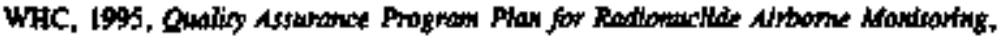
WHC-FP-0S36-3, Westinghoun Hanford Compaly, Richland, Wahington.

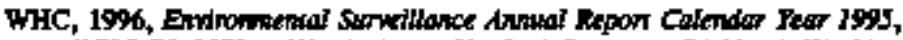

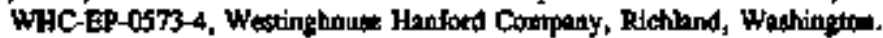

WHC-CM-1-5, Standand Opereaing Prectess, Westinghouse Fanford Compeny, Rlehland, Washington.

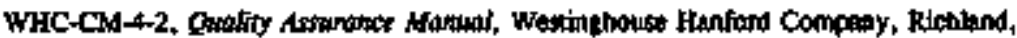
Watinglon.

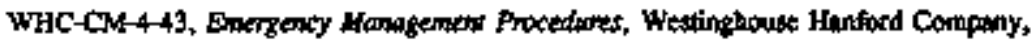
Ricllad, Washingtor.

WHC-CM-74, Operaiond Environnentel Moritaring, Wexinghouse Hanford Company, Richloud, Washitiptort.

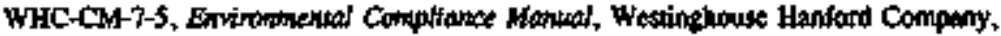
Ricbland, Wathington. 


\section{DISTRDUTION}

Whomber_of Contios

\section{OFFSIIE}

U.S. Dopertoenl of Energy Richland Openarion orfice

J. F. Rovinumsen

R. M. Hiese]

R. 17. Hoit

H. M. Rodtipues?

J. M. Escantillo

E. D. Solkers

Public Reading Room

8

Pexiffe Nordhusest laborakny

W. J. Bjortutind

T. D. Chilalla

G. R. Hoenes

R. E. Jaquiy

G. A. Simiele

R. K. Woodntff

Technical Files

Henfond Tectunical Lubrary
A5-15

S7.41

AS-15

AS-15

57.41

5) -41

H2-53

F.68

P7.75

77.78

$\mathrm{KI}-30$

P7.

K6-13

kJ-11

P8-55

\section{ONFIIE}

I

Dulas Enpineeting and Servios

R. G. LeRoy

HS-30

42

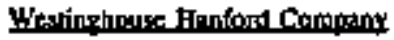

J. M. Bamett

53-95

D. J. ComntI

H6-22

D. L. Dyekman

X(1-2]

1. P. Diediker

T1-30

J. 1. Doriath

H6-30

W. T. Dixon

H6-21

T. P. Frarier (5)

TJ-30 
WHC-EP-D497, REv. 2

\section{DETRIBUTYON}

Nimber of coots

ONSII

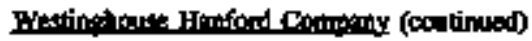

D. W. Fod ' $\quad$ H6-20

E. M. Orater $\quad$ HE 30

D. W. Rering ' Bz-16

L. W. Yanoe

D. D. Volmm H4:16

D. J. Wank X3-79

G. 5 . Humecek (15) X3.79

R. G. Gank X3-79

J. P. Schmidt $\quad$ X3-79

M. A. Green $\times 3.72$

C. Defipl-Price

C. D. Loxis $\quad$ X3:72

C. D. Constunce $\quad$ X3.72

B. J. Hutchins $\quad$ X3.74

Central Files A3-68

DPC (2) A3-74 